Portland State University

PDXScholar

Fall 1-7-2020

\title{
Crania Japonica: Ethnographic Portraiture, Scientific Discourse, and the Fashioning of Ainu/Japanese Colonial Identities
}

Jeffrey Braytenbah

Portland State University

Follow this and additional works at: https://pdxscholar.library.pdx.edu/open_access_etds

Part of the Asian History Commons, and the Asian Studies Commons Let us know how access to this document benefits you.

\section{Recommended Citation}

Braytenbah, Jeffrey, "Crania Japonica: Ethnographic Portraiture, Scientific Discourse, and the Fashioning of Ainu/Japanese Colonial Identities" (2020). Dissertations and Theses. Paper 5356.

https://doi.org/10.15760/etd.7229

This Thesis is brought to you for free and open access. It has been accepted for inclusion in Dissertations and Theses by an authorized administrator of PDXScholar. Please contact us if we can make this document more accessible: pdxscholar@pdx.edu. 
Crania Japonica: Ethnographic Portraiture, Scientific Discourse, and the Fashioning of Ainu/Japanese Colonial Identities

\author{
by \\ Jeff Braytenbah
}

A thesis submitted in partial fulfillment of the requirements for the degree of

Master of Arts
in
History

Thesis Committee:

Kenneth J. Ruoff, Chair

Laura Robson

Jennifer Tappan

Portland State University

2019 
(C) 2019 Jeff Braytenbah 


\begin{abstract}
Japan's colonial activities on the island of Hokkaido were instrumental to the creation of modern Japanese national identity. Within this construction, the indigenous Ainu people came to be seen in dialectical opposition to the 'modern' and 'civilized' identity that Japanese colonial actors fashioned for themselves. This process was articulated through travel literature, ethnographic portraiture, and discourse in scientific racism which racialized perceived divisions between the Ainu and Japanese and contributed to the unmaking of the Ainu homeland: Ainu Mosir. The resulting narrative was used to legitimize Japanese imperialism, transforming the Empire of Japan into the only non-Western member state of the nineteenthcentury global imperialist order. The Ainu on the other hand, were marked as a scientific curiosity, paraded around the world as an anachronistically 'primitive' people destined to disappear, a sacrifice to usher in the progress and glory of the Japanese nation. In recent years, however, after more than a century of coercive assimilation, the Ainu have begun to use some of the methods once employed against them by the Japanese state to refashion their own ethnic and cultural identity, primarily through cultural production, tourism, and by challenging the scientific community that appropriated their ancestral remains. These efforts have, in effect, shifted the Japanese colonial gaze inward revealing the dynamic ethnic and cultural identities that persist in Japan despite nearly one-hundred and fifty years of state-sponsored myths extoling the Japanese nation's cultural, moral, and racial superiority, and later-in the postwar period-homogeneity.
\end{abstract}




\section{Acknowledgements}

I am deeply indebted to many people for their personal and professional assistance over the past several years, most of whom I will no doubt fail to mention here, but to whom I am, nonetheless, forever grateful. I would begin by extending my sincerest gratitude to my family, especially my father and mother, Joseph and Stephanie MacGorvin, but most of all my wife, Natsuko Braytenbah. Were it not for their enduring love and support, I simply could not have made it this far. I would also like to thank the lovely Hōya family for hosting me and generally helping me survive my year of research and Japanese language study at Waseda University in Tokyo, Japan.

I initially became interested in this project during my first year in the graduate program after participating in a meeting sponsored by Portland State University's Native American Student Association that brought together a visiting delegation of local Ainu leaders and politicians from Shiraoi, Japan with Warm Springs tribal representatives from the state of Oregon. My warmest thanks to the participants of this meeting, especially Professor Masami Nishishiba, who extended the invitation for me to attend.

Finally, I would like to thank Professors Ken Ruoff, Laura Robson, Jennifer Tappan, and Katrine Barber, among other faculty members and fellow graduate students at Portland State University, who provided me with invaluable assistance and helped guide me through various stages of this project's development. Talks with Professor Brett Walker of Montana State University also helped me to conceptualize and develop this work. My research was also made possible through financial assistance in the form of teaching assistantships from Portland State University's history department, and other 
generous funding from Waseda University, IE3 Global, and the Lawrence Levy and Pamela Lindholm-Levy Scholarship Fund. 


\section{Table of Contents}

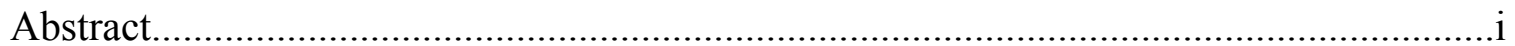

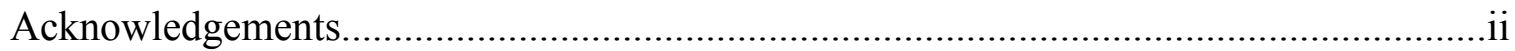

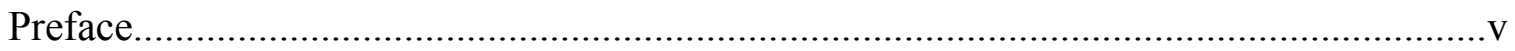

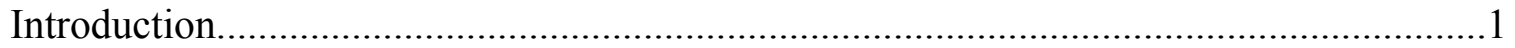

Chapter 1

"A White Race that has Struggled and Lost!": Early Modern Travel Writing, Borders, and Biopolitics in the Unmaking of Ainu Mosir...........................................................13

Chapter 2

Pseudoscience and Sacrilege: Grave-Digging, Anthropometry, and the Complex

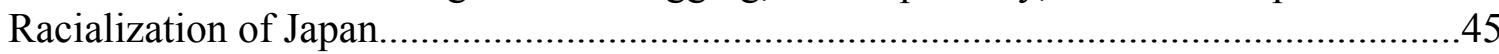

Chapter 3

The Creative Destruction of Ainu Identities: Assimilation, Resistance,

Revitalization.

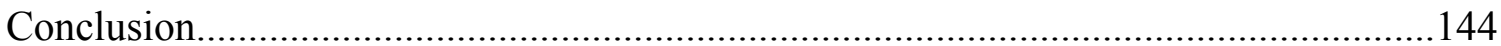

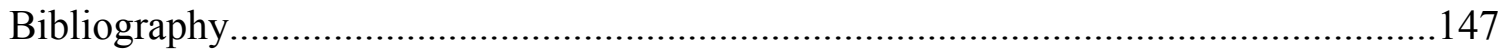




\section{Preface}

I would like to preface this thesis with a brief note on names and places often referenced that may confuse readers. First, let me mention that in the pages that follow Japanese names are written according to custom, meaning surname precedes the given name. Furthermore, I employ the Revised Hepburn romanization method for the names of people, places, organizations, and titles of Japanese works, usually to indicate the presence of long vowels which are marked with a macron, such as $\bar{o}$ and $\bar{u}$. Second, I tend to drop these macrons in the case of well-known locations, such as Tokyo (Tōkyō) and Osaka (Ōsaka), unless they are part of a title of a cited Japanese work. Third, I tend to privilege the repeated use of certain Japanese and Ainu terms in this thesis, though an English translation is provided the first instance that these terms appear, either parenthetically or in the footnotes. The following are important terms used regularly throughout the thesis:

Hokkaido-the large northernmost island of present-day Japan where many Ainu continue to live.

Ainu Mosir-the Ainu name for their traditional homelands meaning "calm land of the humans;" used currently by many Ainu primarily to refer to Hokkaido.

Ezo-a premodern term used by Japanese to refer to both Ainu people and their ancestral lands (primarily Hokkaido, but also the Kuriles, and Sakhalin).

Ezochi-Ainu territory; typically refers to present-day Hokkaido.

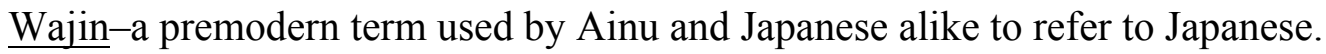

Wajinchi-Japanese settlements on Ezo, present-day Hokkaido. 


\section{Introduction}

"What is an Ainu?" This question, I encountered time and again when discussing my research with people in my home country. You mean, who are the Ainu, I often corrected them. In these moments, the simple knowledge of their people's very existence had begun to feel like some form of arcane knowledge, and I could feel the pulse of dread course through me, a premonition of the comment to follow. "Oh, I just googled it - they were the indigenous people in Japan." Are, they are an indigenous people of Japan, I would respond. In fact, the Japanese government recently passed a law, the Act on Promoting Measures to Realize a Society in Which the Pride of the Ainu People Is Respected (2019) legally recognizing their indigenous status after decades of proclaiming Japan to be "one nation, one civilization, one language, one culture, and one race." Such appeals to homogeneity continue to be a defining hallmark of political, social, and intellectual life in postwar Japan, though in recent years they have begun to ring hollow. Historians have long pointed out that Japanese 'homogeneity' has always been a product of nationalistic, essentialist mythmaking. The Ainu are but one of several peoples that make up the ethnic and cultural diversity of modern Japan. ${ }^{2}$ Other major groups include Zainichi Koreans, Ryūkyūans, and large numbers of Filipino, Brazilian, Chinese, Vietnamese, and Nepalese residents.

\footnotetext{
${ }^{1}$ The quote is taken from a speech by former Prime Minister (current Deputy Prime Minister and Minister of Finance) Taro Aso. At the time of the speech he was serving as Minister of Foreign Affairs. "Aso Says Japan is Nation of 'One Race,' The Japan Times, October, 18, 2005; Chris Burgess, "Multicultural Japan' Remains a Pipe Dream," The Japan Times, March 27, 2007.

${ }^{2}$ Japan Ministry of Justice, Zairyū gaikokujin dōkei [Statistics on Foreign Residents], July 25, 2019. These census figures are from December, 2018. https://www.e-stat.go.jp/stat$\underline{\text { search } / \text { files} ? \text { page }=1 \& \text { layout }=\text { datalist } \& \text { toukei }=00250012 \& \text { tstat }=000001018034 \& \text { cycle }=1 \& \text { year }=20180 \& \mathrm{mo}}$ $\underline{\mathrm{nth}}=24101212 \&$ tclass $1=000001060399 \&$ stat infid $=000031832809$
} 
My conversations with many Japanese with whom I discussed my work revealed that they, too, generally knew very little about their indigenous neighbors in the north of their own country. Many claimed to have never learned about them in school, or at least they could not recall. A few mentioned their visits to Shiraoi or Lake Akan, ${ }^{3}$ popular travel destinations in Hokkaido, Japan's northernmost island, where Ainu members engage in ethnotourism enterprises, displaying their arts and crafts, and performing songs, dances, and religious rites for Japanese and foreign spectators. Many young people recommended that I read/watch Golden Kamuy, ${ }^{4}$ the recent award-winning manga-anime series set in Hokkaido after the Russo-Japanese War (1904-1905), which I feel is a fine example to illustrate my next point.

Past depictions of the Ainu in Japanese popular culture were often heavily influenced by racialist discourse, casting them as aging, primitive, lacking in intellectual faculties, with hirsute bodies and broad, deep-set Caucasian facial features. Golden Kamuy fails to break this mold, though it does manage to put at least a few cracks in it. For instance, one of the story's main Ainu characters is a confident, sharp-witted, and winsome adolescent huntress. Moreover, its creators treat Ainu culture respectfully, displaying a wide range of local diversity among communities in exhaustive anthropological detail. ${ }^{5}$ Yet, it is a fictional account, after all, containing within it its own work of fiction, a wholly ahistorical depiction of Ainu life that glosses over the traumatic reality inflicted upon them during this period.

\footnotetext{
${ }^{3}$ These tourist sites will be discussed in more detail in chapter three.

${ }^{4}$ Satoru Noda, Gōruden Kamui [Golden Kamuy] (Tokyo: Shueisha, 2014-present).

${ }^{5}$ Nakagawa Hiroshi, a professor of literature at Chiba University and specialist in Ainu language and folklore, works as a consultant on the series.
} 
The Ainu culture first appeared in the thirteenth century in areas of what are today Japanese and Russian territory, though their ancestors who were part of the earlier Satsumon and Okhotsk cultures had been there for thousands of years. The island of Hokkaido was the center of the historical Ainu homeland, Ainu Mosir, ${ }^{6}$ though in smaller numbers Ainu peoples also settled the Kurile Islands, Sakhalin, and the southern tip of Kamchatka to the north, and the northern regions of Honshu to the south. By the mid-tolate seventeenth century, as Japanese settlement and commercial activities in Hokkaido began to increase, so too did the ecological devastation, violence, forced labor, and epidemic diseases carried from mainland Japan that ravaged Ainu communities bringing about their sharp demographic decline. There were likely between 40,000 and 80,000 Ainu residing in these areas before Japanese encroachment, but by the time of the RussoJapanese War only 17,783 were counted within their communities, all of which were by this time firmly under Japanese control. ${ }^{7}$

Golden Катиy attempts to foster appreciation for Ainu culture among its readers by basing its portrayal on sound archaeological and anthropological evidence though it presents traditional Ainu lifeways in a complete historical vacuum. Ainu communities in the story are shown to be living in relative prosperity and practicing their culture and customs freely. By the years depicted in the story, however, Hokkaido had become Japan's first full-scale settler colony with over a million immigrants from the mainland residing there. ${ }^{8}$ As Lorenzo Veracini explains, settler societies "often aggressively

\footnotetext{
${ }^{6}$ Meaning the "calm land of humans." The name Ainu was a self-identifying term meaning "human," or "the people."

${ }^{7}$ Richard Siddle, Race, Resistance and the Ainu of Japan (New York: Routledge, 1996), 59; Emori Susumu, Ainu no rekishi: Hokkaidō no hitobito, vol. 2 (Tokyo: Sanseidō, 1987), 126.

${ }^{8}$ Ibid.
} 
displace indigenous people in a variety of ways: by assimilating them, by killing them off, or more often by preventing them from accessing traditional resources in the context of a zero-sum contest." ${ }^{\prime 9}$ In the case of Meiji Japan, killing the Ainu was unnecessary, as they lacked sufficient numbers or means to pose any military threat and violent resistance of any kind had long ceased. Moreover, Japan had substantially increased its military and economic power to the point of parity with many European powers - they defeated the Russian empire, after all. The Meiji government instead instituted a series of programs designed to make Ainu into 'useful' 'Japanese' citizens. This was to be accomplished through laws that forbade Ainu cultural practices, forced relocations from their land, school curricula that trained Ainu youth in Japanese language and cultural habits while punishing them for speaking their own language, and placement on reservations where the Ainu, a hunter-gathering people, were made to become farmers under the watchful eyes of state bureaucrats.

At the same time, Japanese researchers trained in Western letters and sciences scoured Hokkaido's countryside searching for Ainu remains to collect, study, and decode, to understand how they fit into the Western racial hierarchy they had come to accept as a biological certainty. Their Western counterparts had already developed a strong interest in the Ainu believing them a stranded group of long lost white cousins, "an island of Caucasoids in a sea of Mongoloids," though Japanese researchers sought to investigate the matter for themselves. ${ }^{10}$ This intellectual movement arose out of the harsh

\footnotetext{
${ }^{9}$ Lorenzo Veracini, "Understanding Colonialism and Settler Colonialism as Distinct Formations," Interventions 16:5 (2014), 626.

${ }^{10}$ John A. Harrison, "The Saghalien Trade: A Contribution to Ainu Studies," Southwestern Journal of Anthropology 10:3 (1954), 278.
} 
geopolitical world of the late nineteenth and early twentieth centuries, and came to embody its stark Manichean contrasts: belief in the rule of 'Western' empires over 'the rest,' the triumph of 'civilization' over the 'barbaric,' the promise of 'progress' against a fading 'primitivism,' and beneath it all the unscalable hierarchy of scientific racism. Today, the academic consensus on the concept of "race" is that it is a social construction, a reflection of prejudice against — what are sometimes but not always — perceptible human differences manifested in human societies, though ultimately contingent upon the power dynamics and social realities of the historical moment. It is not, therefore, a meaningful biological category. The Western-dominated academic consensus prior to the contemporary study of genetics, however, told a different story: that humanity was fundamentally unequal in mind and body, that these were not individual traits but immutable differences among human groups, and that status in this racial hierarchy was beyond skin deep - it could be traced along the contours of our skulls resting underneath.

It was in this context, I argue, that Japan's colonial activities on the island of Hokkaido became instrumental to the creation of a racialized Japanese national identity, and that through this construction Japanese political and intellectual leaders also seized the power to impose new colonial distinctions on the Ainu, whom they placed in dialectical opposition to the 'modern,' 'civilized' self-images they fashioned for themselves. Japanese leaders employed this new conception of identity to legitimize their nation's colonial mission, and to transform their country into the only non-Western member of the global imperialist elite. The Ainu on the other hand, like indigenous peoples elsewhere, were marked as a scientific curiosity, 
an anachronistically "primitive" people destined to "vanish, ${ }^{11}$ their forced

assimilation a sacrifice of sorts to usher in the progress and glory of an ascendant Japanese nation.

This venture into racialist territory was new, but the dialectical relationship between the Japanese and Ainu was not. It had been articulated in different forms before through travel literature, cartographic expeditions, biopolitical experiments, and ethnographic portraiture as Japanese interests in Ainu Mosir slowly grew from the seventeenth century to the Meiji years. The first chapter of the analysis that follows examines this process by tracing the change in Japanese perceptions of the Ainu and their homeland. Initially, Japanese officials envisioned it as an alien space inhabited by people as foreign to them as the Chinese, Koreans, or even Europeans. However, as Japanese economic, political, and cultural activities on its northern periphery grew in importance, their perceptions of Ainu Mosir were reimagined as a place within the Japanese cultural and political orbit, no longer foreign though not quite 'Japanese,' a phenomenon I refer to as the "unmaking of Ainu Mosir."

The second chapter details Japanese modernization in the Meiji period and the role that Western ideas of scientific racism and Social Darwinism played in the formation of the Japanese physical and social sciences. In turn, these intellectual pursuits were aided by the rapidly developing colonial infrastructure in Hokkaido, while Japanese researchers helped to promote and legitimize imperial expansion.

\footnotetext{
${ }^{11}$ The Ainu, among other indigenous peoples in the world, were believed to be racially inferior and incapable of adapting to the rapid pace of change in the nineteenth- and twentieth- century world. The conquest of indigenous lands and indigenous peoples' susceptibility to epidemic disease outbreaks of Eurasian origin contributed to this belief as well. The standard view within the sciences was that such peoples would inevitably become extinct.
} 
The study of Ainu bodies, especially skulls and other human remains, became crucial to the question of Japanese national origins and their 'true' racial identity. In pursuing this research, Japanese academics joined a fraternity of Western researchers already entranced by the Ainu's supposed Aryan origins. Japanese policymakers used their subjugation of Europe's 'Caucasoid' cousins to project their nation's own power in the international arena, and to question the underlying logic of the Western racial hierarchy which placed whites at the top and the Japanese below them.

Finally, chapter three complicates our current understanding of Ainu identity in the present by looking at the dynamic tension existing between activists, Ainu figures working in ethnotourism, and others who prefer to conceal their Ainu identity both in public and private. The chapter details the effects of the Meiji government's forced relocations and assimilation programs on Ainu communities, and how, later, many within the Ainu elite came to support these efforts as the only viable means of ameliorating the ongoing problems of discrimination and poverty. The drive to create the assimilation programs had been spearheaded decades earlier by a liberal humanitarian circle of Japanese academics, bureaucrats, and professionals who found inspiration in Native American residential schools and the Dawes Act in the United States. Though they advocated for Ainu welfare, most could not escape their own racialist thinking on the Ainu question. Meanwhile, as tourism to Hokkaido grew, some Ainu found a space where they were able to perform and revitalize cultural identities that the Japanese government and activists within the Ainu elite were attempting to eradicate. Decades later, in the 1960s and 
1970s, a new wave of radical Ainu activists rose to challenge the logic of assimilation, choosing instead to confront and denounce the institutions of colonial oppression. They partnered with Ainu in ethnotourism to create new symbols and histories of their people. Eventually, even conservative Ainu leaders followed suit, as Ainu representatives became more involved in the global movement for indigenous rights ${ }^{12}$ and used international institutions like the United Nations to pressure the Japanese government into recognizing their new identity as an indigenous people of Japan.

This analysis sheds new light on several crucial issues within the field. Understanding the first one is vital to interpreting the content and organization of this thesis itself. That is to say, I have attempted to apply a schema that decenters but does not "provincialize"13 Japan's role in the history of Ainu lands. In attempting this, I have taken cues from the previous work of notable scholars, such as David Howell, Brett Walker, Kikuchi Isao, and Tessa-Morris Suzuki. Readers will notice the change in names of places and groups of people, sometimes within the same chapter. To make things clear: I use the term Ainu Mosir conceptually to demonstrate that present-day Hokkaido was not 'Japanese' territory until the modern period, even though there were Japanese settlements there (Wajinchi). Wajin is a term that was used to describe Japanese people in the premodern period and was

\footnotetext{
${ }^{12}$ This movement saw a coalescing of indigenous groups from around the world working together to share political, legal, environmental, and preservation strategies. One pivotal moment in the growth of the movement was the creation of the World Council of Indigenous Peoples in 1974.

${ }^{13}$ See Dipesh Chakrabarty, Provincializing Europe: Postcolonial Thought and Historical Difference (Princeton: Princeton University Press, 2008). My goal here is not to focus on an "Ainu history" per se, and place Japan in the role of an outside actor peripheral to the Ainu. Rather, I emphasize how dialectical identities were formed for both groups usually by Japanese actors due to the unequal power relationship that developed, though Ainu agency is well-documented here. This is a "shared" history we are exploring.
} 
common in contemporaneous writings. Japanese during this period referred to the Ainu as "Ezo," and to Ainu lands through various terms (Ezo, Ezochi, Ezogashima, etc.). For simplicity's sake, I employ the term Ezochi to designate areas of Ainu settlement. I do not use the term "Ainu Mosir" to specifically refer to territory, as it is to some extent a modern construction used by Ainu activists. ${ }^{14}$ Generally, Ainu peoples had linguistic and cultural features that created some sense of unity among them, but they were a people who conceived of their communal and political spaces locally in the form of kotan (village chieftainships). As such, there were substantial differences between local and regional Ainu groups.

Many scholars choose to speak of "Hokkaido history" in the premodern period, but a place of this name simply did not exist before 1869 . The designation of Hokkaid̄̄ — the present name of Japan's northernmost island — in this analysis, represents (1) a complete transformation in Japanese perspectives of cultural and political space, and (2) the placement of administrative colonial infrastructure to project the power of the modern Japanese state. Therefore, readers will find that I rarely use the terms "Ezo, Wajin, Wajinchi, and Ezochi" by the second chapter, and instead use "Japanese, Ainu, Hokkaido," and other contemporary names for nearby regions.

\footnotetext{
14 'Ainu Mosir' is a term that refers to an ancestral Ainu homeland, though this is a difficult concept to apply in a historical sense. Conceptually, its meaning appears more spiritual than geographical, hence its use by contemporary activists who are trying to shape a new collective identity amongst each other in the present, though historically Ainu groups were far from united. See Richard Siddle, "The Making of Ainu Moshiri: Japan's Indigenous Nationalism and its Cultural Fictions," in Nationalisms in Japan, ed. Shimazu Naoko (New York: Routledge, 2006).
} 
This approach positions the history of Japanese activities on its northern periphery squarely within the nation's imperial history. In essence, Hokkaido represents modern Japan's first flirtations with empire in the modern period, decades ahead of the acquisitions of Taiwan and Korea. There is no shortage of scholarship on imperial Japan, though the tendency in the field is still to ignore Hokkaido in this discourse, a problem in that many of the features of later Japanese imperialism, like forced assimilation directed against Koreans and Taiwanese Aborigines, were initially shaped by Japan's experiences with the Ainu. Hokkaido was a testing ground for an even more aggressive imperialism that came later, if you will. Furthermore, it is still rare to see names like Foucault in studies of Japanese imperialism. In this work, I touch on Foucauldian biopolitics to explain Japanese mid-nineteenth-century efforts to provide smallpox vaccinations to Ainu communities to engender loyalty to the Japanese state.

I was similarly inspired by Mary Louise Pratt to look at Japanese ethnography, travel literature, artistic depictions, and academic discourse concerning the Ainu. Also, I found Londa Schiebinger's concept of "bioprospecting" useful for studying JapaneseAinu relationships. In the context of premodern Japan, doctors and nature enthusiasts journeyed all the way north to Ainu territories and made use of the indigenous knowledge of the environment to procure rare materia medica. This led to more books being written about the Ainu and greater familiarity with them among the Japanese public. As evidenced here, analyses of this type can reveal changes not only in intellectual trends but also in conceptions of peoples and the places they inhabit. Marcia Yonemoto's treatment of Tokugawa-period maps was also instrumental to my understanding of the role 
cartography projects in the eighteenth and nineteenth centuries played in altering the Japanese view of political and territorial space. Brett Walker's studies of premodern vaccines and geographical surveys also helped guide my research in this area. I also looked to the work of Patrick Wolf and Lorenzo Veracini to help ground my research in the study of settler colonialism. Hokkaido was very much a Japanese settler colony by the early Meiji period, and failing to acknowledge this creates vast problems of teleology, essentially confirming Hokkaido as a natural extension of Japanese national territory, a perspective that virtually erases the Ainu's history there.

The role of scientific racism and Social Darwinism in shaping the attitudes of Meiji-era politicians and academics is fundamental to my analysis. Richard Siddle has exhaustively researched the racialization of the Ainu during this period and how it related to the Japanese government's subjugation of them. My approach diverges from his in that I examine how the Western concept of race influenced dual-identity formations in the case of the Ainu, ${ }^{15}$ as well as how it was instrumental in constructing the national identity of the Japanese. Western racial theories were adopted and culturally mediated by Japanese elites in such a way that the nation's imperial conquests and mastery over subject peoples was predicated on their racial self-images. We can see this in Japanese artistic depictions of the Sino-Japanese War (1894-1895) for example, wherein Japanese soldiers don modern military uniforms and display 'Caucasian-like' features contrasting them with Chinese soldiers who were rendered darker and in traditional robes. It was during this time that research into Japanese and Ainu origins was entering a more serious

\footnotetext{
${ }^{15}$ This refers to the reality that Ainu from the Meiji period onward have had to process their identities as Ainu while also living as Japanese in mainstream society.
} 
phase. Therefore, the role of the Ainu was pivotal, as Japanese elites began to juxtapose 'Caucasian' Ainu 'primitiveness' with their own self-ascribed racial identity as a means of challenging the existing white-dominated racial hierarchy, and to raise their nation's status and prestige on the global stage.

One final contribution of this work is that it adds potential new layers to global indigenous studies. While the number of contemporary researchers of the Ainu has indeed grown slowly over the last two decades, it continues to lag behind the attention paid to many other indigenous groups. This is indeed troubling as the majority of English-language scholarship and media attention paid to the Ainu just a few decades ago was still very much of the 'dying' race variety, with titles as problematic as “Japan's Sky People: The Vanishing Ainu" (1967), Together with the Ainu: A Vanishing People (1971), and The Ainu: The Past in the Present (1977). ${ }^{16}$ Perhaps Japan's recent acceptance of Ainu indigeneity will increase the pool of scholars of Ainu history and generate new and important content. Danika Medak-Saltzman is a great example of such a figure, one who has bridged the Native American and Ainu colonial experiences, and her work on the transnational encounters of indigenous peoples staged in the "living peoples exhibits" at World Fairs helped me to conceptualize my own project. This thesis will trek into very different territory than that found in her material, but first we shall take a brief but important detour to the American Midwest near the turn of the twentieth century.

\footnotetext{
${ }^{16}$ M. Inez Hilger, “Japan's Sky People: The Vanishing Ainu” National Geographic 131:2 (February 1967), M. Inez Hilger, Together with the Ainu: A Vanishing People (Norman: University of Oklahoma Press, 1971) and Fred C.C. Peng and Peter Geiser, The Ainu: The Past in the Present (Hiroshima: Bunka Hyoron, 1977).
} 


\section{Chapter 1}

"A White Race that has Struggled and Lost!" 17 ":

Early Modern Travel Writing, Borders, and Biopolitics in the Unmaking of Ainu Mosir

On April 30, 1904, spectators who had journeyed far and wide across the United States poured into St. Louis for the opening of the Louisiana Purchase Exposition. The "Gateway to the West," as St. Louis had become known, was designated as a prime location for the event, a celebration of American industrial might and scientific progress at the turn of the twentieth century. The St. Louis Exposition was in many ways a reiteration of the World's Columbian Exposition held in Chicago eleven years prior. Yet, whereas the Chicago exhibition celebrated the voyages of Columbus and the European discovery of the Americas with a focus on the Atlantic world, the St. Louis Exposition differed in its joining of visions of a grand positivistic future with the historic allure of the American Western frontier. Of course, by this point in time the United States' expansionist "destiny" had already manifested well beyond its western continental shores in military and commercial ventures in far off Hawaii and the Philippines, and further still in the "gunboat diplomacy" employed against Japan.

Historians today may still disagree on how to define nineteenth and twentiethcentury American interests in the deep Pacific, namely to what extent they can accurately be described as truly imperialistic and colonial, as opposed to merely violently commercial. What cannot be ignored, however, is the myriad ways in which American

\footnotetext{
${ }^{17}$ The title is taken from a quote in Frederick Starr, The Ainu Group at the Saint Louis Exposition (Chicago: The Open Court Publishing Company, 1904), 110. Starr, an anthropologist at the University of Chicago, was hired by the director of the Anthropology exhibit at the St. Louis Exposition to travel to Japan and collect Ainu participants and artifacts for the 'living exhibits' section. His account here is more of an ethnographic travelogue than an academic study, a fact he readily admits in the preface. Such accounts by anthropologists were common during this period as a way to profit personally and gain prestige for both themselves and the budding discipline as a whole.
} 
involvement in the Pacific captured the minds of the public. Even smaller cities, such as Portland, Oregon, staged expositions with live exhibits of indigenous Igarot peoples from the Philippines alongside indigenous tribes from the Columbia Plateau. ${ }^{18}$ This particular case - the 1905 Lewis and Clark Centennial Exposition — fused the concept of manifest destiny from the preceding century with the nation's contemporaneous Pacific exploits, and it elucidates how American expansion into already occupied indigenous lands had been steeped in the centuries-old dialectics of "civilization/savagery," "modern/primitive," and "superior/inferior races." Such notions helped erect the very foundations of Euro-American imperialism, and later, largely by way of Western influence, Japan's own imperial expansion.

Living peoples exhibits were carefully staged to present the participants as "primitives" and they became a mainstay at World Fairs. Such exhibits, more colloquially known as 'human zoos,' used the bodies of indigenous peoples to represent the lowest rungs on the evolutionary ladder. According to William J. McGee, the head of the anthropological section at the St. Louis Exposition, this was done not to satisfy a base curiosity for the strange and exotic among the general public, but to instill in the "intelligent observer that there is a course of progress running from lower to higher humanity." ${ }^{\prime 19}$ This was indeed a clear expression of Western racialist thought at the turn of the twentieth century, and the thick "color line" that imperialist nations had drawn

\footnotetext{
${ }^{18}$ Emily Trafford, "Hitting the Trail: Live Displays of Native American, Filipino, and Japanese People at the Portland World's Fair," Oregon Historical Quarterly 116:2 (2015). Also, see Carl Abbott, The Great Extravaganza: Portland and the Lewis and Clark Exposition, $3^{\text {rd }}$ ed. (Portland: Oregon Historical Society Press, 2004). Robert W. Rydell, All the World's a Fair: Visions of Empire at American International Expositions, 1876-1916 (Chicago: University of Chicago Press, 1984).

${ }^{19}$ W.J. McGee, “Anthropology at the Louisiana Purchase Exposition,” Science 22 (December 1905), 826.
} 
across the globe. ${ }^{20}$ In Peoples on Parade, Sadiah Qureshi argues that "exhibitions were far from peripheral to these debates [race, progress, civilization, etc.]; rather, ethnologists and anthropologists both recognized and exploited the research opportunities that the shows made possible, ${ }^{21}$ as indigenous bodies were presented as objects for both spectator amusement and academic scrutiny. The fact that nine Ainu men, women and children from the Japanese-annexed island of Hokkaido were, with the blessing of the Japanese government, brought across the Pacific to participate in the St. Louis Exposition shows the extent to which Japanese policymakers and intellectuals had succumbed to the racialization of humankind, and the classification of global indigenous peoples as "vanishing races." In fact, just the previous year the Japanese government had staged a similar event in Osaka, fitted with the very same model of indigenous exhibits demonstrating its own imperial designs in East Asia. The event featured indigenous peoples from Taiwan, the Ryukyus, and of course Ainu participants from Hokkaido living in mock villages created to entertain, but also to instruct an eager Japanese public in how to view the logic of colonialism through the display of "primitive" peoples brought under the yoke of the modern Japanese nation.

Events like the Osaka and St. Louis Expositions were articulations of longstanding structures of colonialism begun in the preceding centuries. In the Japanese case, much of the general historiography of that nation's imperialism places its origins in the aftermath of the Sino-Japanese War (1894-1895) with Japan's acquisition of Taiwan.

\footnotetext{
${ }^{20}$ See Marilyn Lake and Henry Reynolds, Drawing the Global Colour Line: White Men's Countries and the International Challenge of Racial Equality (Cambridge: Cambridge University Press, 2008).

${ }^{21}$ Sadiah Qureshi, Peoples on Parade: Exhibitions, Empire, and Anthropology in Nineteenth-Century Britain (Chicago: The University of Chicago Press, 2011), 6.
} 
Yet, more recently scholars have recognized that this approach ignores Japanese expansion into the Ryukyu Islands and Hokkaido that began in the early part of the Edo period (1603-1868). ${ }^{22}$ This fact has long been overlooked in most traditional scholarship that tended to emphasize the xenophobic and inward-looking elements of sakoku (closedcountry) policy at the expense of understanding the nature of experiences occurring on the geographical margins of Tokugawa society. Therefore, if we are to understand the historical roots of Japanese imperialism and its intersections within dialogues of racism and modernity, then we need examine both the lived and imagined dynamics of Japanese relations with peoples in these borderland areas, peoples like the Ainu of present-day Hokkaido.

In Imperial Eyes Mary Louise Pratt argued that European travel narratives gave "reading publics a sense of ownership, entitlement and familiarity with respect to the distant parts of the world that were being explored, invaded, invested in, and colonized. ${ }^{, 23}$ I would extend this argument in two ways: first, the process described by Pratt can also be applied to studies of Japanese colonialism; second, travel narratives were not only fundamental to the way colonial societies conceived of foreign lands, but also in how they fashioned identities for both colonizers and the colonized alike. This chapter will examine how Japanese ethnographic travel narratives, cartographic projects, and biopolitical enterprises contributed to the colonization of Ainu lands. I also aim to

\footnotetext{
${ }^{22}$ This reinterpretation of premodern Japanese-Ainu borderlands continues to grow in popularity due to the scholarship of Kikuchi Isao, David Howell, and Brett Walker among others. See Kikuchi Isao, Ainu minzoku to Nihonjin: Higashi Ajia no naka no Ezochi (Tokyo: Asahi Sensho, 1994), David L. Howell, Geographies of Identity in Nineteenth-Century Japan (Berkeley: University of California Press, 2005), and Brett L. Walker, The Conquest of Ainu Lands: Ecology and Culture in Japanese Expansion, 1590-1800 (Berkeley: University of California Press, 2001).

${ }^{23}$ Mary Louise Pratt, Imperial Eyes: Travel Writing and Transculturation (New York: Routledge, 1992), 3.
} 
historicize the configuration and reconfiguration of Japanese/Ainu colonial identities that occurred throughout the premodern period and up to the beginning of the Meiji period, the dawn of Japanese modernity.

The Japanese colonization of Ainu territory was a long process begun in the early seventeenth century and culminating in the full incorporation of the island of Hokkaido in 1869 into the fledgling Meiji state. These activities were influenced by the scientific discourse of the time, whether it be Edo-period honzōgaku studies or Western scientific racism and social Darwinism in the late nineteenth and early twentieth centuries. By the end of the premodern period Japanese imperial agents viewed Hokkaido as a natural extension of their political territory in a process that required the erasure of Ainu people from the conceptual human future as well as from their lands. This is what I describe as the unmaking of Ainu Mosir, ${ }^{24}$ a process that by the late nineteenth century came to be articulated in terms of a dialectical racialist model that placed the "modern/civilized" Japanese in opposition to the anachronistically "primitive" Ainu.

\section{Ethnographic Accounts of Ezo in Japanese Antiquity}

The systematic colonization of Ainu Mosir began in 1604 with the Tokugawa shogunate's grant of exclusive trading rights to the Matsumae clan over a small area on the Southern Hokkaido coastline. The Matsumae grant was not a kokudaka (a fief or allotment of agricultural land) typical of Tokugawa territorial administration, but a recognition of the Matsumae's exclusive commercial rights with the residents of Ezochi,

\footnotetext{
${ }^{24}$ In the Ainu language the words 'Ainu' (human) and 'mosir' (land) are combined into 'Ainu Mosir' (calm land of the humans) which refers to their traditional homeland territories in the regions of northern Tohoku, Hokkaido, the Kuriles, and southern Sakhalin.
} 
the land inhabited by peoples referred to as Ezo. ${ }^{25}$ Initially, the term Ezo referred not only to Ainu but other groups in the North Pacific region near Japan, including the less numerous Uilta and Nivkh peoples, but gradually as Japanese-Ainu contact increased during the Warring States period 'Ezo' came to refer almost exclusively to the Ainu. The Ainu culture developed around the thirteenth century out of the preceding Okhotsk and Satsumon cultures of Northern Japan, the Kurile Islands, and Sahkhalin, although by the early modern period most Ainu communities were situated in present-day Hokkaido. It should be noted that the term 'Ainu' refers to a self-identified ethnic group with shared cultural associations that bound together what were, historically, politically disparate communities. These communities varied linguistically though they shared much in the way of religion, lifeways, and economic activities centered on hunting, gathering, fishing, small-scale agriculture, and marine trade.

In fact, Ainu trading networks were vast connecting Ainu Mosir with continental Northeast Asia and Japan, and the desire to gain access to these trade networks was what initially motivated 'Wajin' (premodern Japanese peoples) to travel to and settle in Ezochi prior to the Edo period. These small Wajin settlements in Ezochi were formed during the Japanese medieval period through a combination of exiled prisoners, small-scale fishermen, merchants, and wayward warriors from northern Tohoku, but by the twilight of the Sengoku period (c. 1467-1600) the Kakizaki clan (renamed Matsumae) gained military control over the Japanese settlements. During the wars of reunification in the sixteenth century, the Kakizaki family were recognized as daimyo (official domain lords)

\footnotetext{
25 'Ezo' is a reading of the characters 蝦夷 which before the Kamakura period (1185-1333) was read as 'emishi' and referred to the peoples of Northeastern Japan who lived outside the political boundaries of the Japanese state. 'Ezo' was also used to refer to the island of Hokkaido itself. Walker, Conquest, 37-39.
} 
and as the Warring States period drew to a close their territories were brought under the political umbrella of the Tokugawa shogunate. Because of the distance between Edo and Ezochi, however, the Tokugawa government had very little direct presence there. ${ }^{26}$

The earliest Japanese ethnographic portrayals of the Ainu date to the Medieval period, although references to the Emishi (an older term referring to peoples on Japan's northern periphery) can be found in the Kojiki and Nihon Shoki, two of the earliest written works in Japanese history. The first known Ainu visuals are found in the Shotoku taishi denryaku (Illustrated Biography of Prince Shotoku), a series of hanging scrolls compiled in the fourteenth century. The most well-known among these is the oldest one painted by Hata no Chitei in 1069 in which an Emishi leader named Ayakasu is seen submitting to the emperor after a failed revolt. ${ }^{27}$ According to legend, in the sixth century a young Prince Shotoku — at the ripe age of ten — ventured all the way to what some scholars believe was Hokkaido in order to put down a rebellion there. Of course, we are dealing with mytho-history here and it is problematic to conflate the Emishi with the Ainu, although some scholars believe the Emishi to be the ancestors of the Ainu, and most believe that there is surely some cultural connection between the two. Regardless, there are several additional scrolls in the collection that also feature Emishi figures from mythical tales of Japanese antiquity, though these were painted in the fourteenth century well after the rise of Ainu culture. Many scholars of Ainu-e (paintings of the Ainu)

\footnotetext{
${ }^{26}$ From this point on my use of 'Ezochi' will refer specifically to the present-day island of Hokkaido, unless otherwise specified. The term 'Wajin' is a compound reading of the characters 倭 (ancient Japan) and ( (person/people). The term can also be written as 和人 in more contemporary form. Similar to 'Ezochi' the term 'Wajinchi' (Japanese land or territory) was used in historical sources to refer to those areas of present-day Hokkaido inhabited by Japanese peoples.

${ }^{27}$ This painting is part of the regular collection at the Tokyo Kokuritsu Hakubutsukan (Tokyo National Museum) located in Ueno Park.
} 
believe that these artists used contemporaneous Ainu physical characteristics as inspiration for their creative interpretation of the Emishi, believing the two groups to be one and the same. The subjects in the paintings can be said to share some familiar Ainu traits but certainly some imaginary ones as well.

For example, many of the men in the paintings have the trademark long hair, beards, and clothing of the Ainu, but others are shown in fashions unknown to Ainu society. One man in particular can be seen in a skirt made of bird feathers, a fashion that would have been as curious to Ainu onlookers as it would have been to Japanese. One of the purposes for including oddities like this in a depiction of foreign peoples - the Ainu were during this period considered very much a foreign people by the Japanese-is that they expressed the civilized (kyōka) and barbarian (iteki) axioms of the Confucian moral and political order, concepts that were imported from China between the sixth and seventh centuries and adapted to fit Japanese society in the centuries that followed. ${ }^{28}$ David Howell explains that for premodern Japanese, in both art and life, "outward symbols of civilization, including clothing, hairstyles, and languages, distinguished the subjects of the Japanese state from the people of the peripheries. ${ }^{29}$ In the popular Edoperiod illustrated encyclopedia, Wakan sansai zue, for example, the Ainu, Okinawans, Chinese, and Koreans were considered peoples from outside countries $(i k o k u)$ connected to the official Edo diplomatic sphere, while more distant peoples, such as those from Holland, the Philippines, and England were categorized as outside barbarians (gai' $i$

\footnotetext{
${ }^{28}$ This concept is also referred to as ' $k a-i$ shisō' (Thoughts on civilization and barbarianism or 'Middle Kingdom Ideology') in various sources.

${ }^{29}$ Howell, Geographies, 5 and Tessa Morris-Suzuki, Re-Inventing Japan: Time, Space, Nation (New York: Routledge, 1998), 14-20.
} 
jinbutsu); and beyond Europe, according to the text, lay the lands of mythological cyclopean, bird, and fish peoples. ${ }^{30}$ The point being, in premodern Japan the farther groups of people were from the geographic and cultural center (generally Kyoto), the less civilized they were thought to be due to differences in custom (füzoku), with the most distant peoples taking on grotesque and inhuman characteristics.

Other examples of this relating directly to the Ainu can be found in both the text of the Suwa Daimyojin ekotoba picture scroll of 1356 —only the text portion of the scroll survives today in various manuscript forms - and the Seisuiji en'gai painted in $1517 .{ }^{31} \mathrm{In}$ both, the Ainu are depicted as ogres, demons, and ghoulish enemies of Buddhism because of their distance from the virtues of the Japanese political center. Sasaki Toshikazu explains that in the case of the Seisuiji en'gai "painters from the Tosa school lacking any knowledge about the Ezo used these fiendish figures to represent them., ${ }^{32}$ Both works commemorate military victories over the Ezo in the medieval period and represent premodern Japanese views of the peoples on their northern periphery in strictly cultural terms prior to the advent of Japanese expansion into Ezochi.

\section{Contextualizing Ezo Colonialism and Exoticism in the Early Edo Period}

\footnotetext{
${ }^{30}$ Terashima Ryōan, Wakan sansei zue [1713], vol. 1, (Tokyo: Nihon zuihitsu taisei kankōkai, 1929), 202246, Central Library, Waseda University. Manuscript copies of various volumes are also available online through The Ohio State University Library.

${ }^{31}$ Isao Kikuchi, "Early Ainu Contacts with the Japanese," in Ainu: Spirit of a Northern People, ed. William W. Fitzhugh and Chisato O. Dubreuil (Arctic Studies Center, National Museum of Natural History, Smithsonian Institution: Washington D.C., 1999), 74-77.

${ }^{32}$ Sasaki Toshikazu, “Ainu-e: A Historical Review," in Ainu: Spirit, 81.
} 
As discussed earlier, many scholars date the Japanese colonization of Hokkaido to 1869 , the point at which formal annexation of the island was established by the nascent Meiji government in Tokyo. However, the Ainu's plight began not under direct colonial rule in the Meiji period, but in 1604 with the Tokugawa Shogunate's grant of exclusive trading rights with the Ezo to the Matsumae clan. Economic conditions made the Matsumae clan dependent on the growth of Japanese-Ainu commerce as opposed to rice agricultural common in most areas of early modern Japan, and so they set strict protocols regulating these trade relationships. ${ }^{33}$ The post-unification economy of the Tokugawa period gradually strained Hokkaido's environment through overfishing and the dumping of mining waste, while the proliferation of Japanese trading posts on the island brought epidemic diseases, such as smallpox, measles, and tuberculosis to the local Ainu populations in greater frequency resulting in high death rates in many communities. ${ }^{34}$ Walker argues that these forces were instrumental to the Ainu's economic subjugation, as many communities adapted to the changing conditions by abandoning traditional subsistence methods as they came to depend more on food and other imports accessible only within the Japanese-dominated market economy. This had a crippling effect on Ainu social and political structures, weakening their means of defense against Japanese aggression and encroachment on their territory.

The event known as Shakushain's War (1669-1672) was a seminal moment in the history of the Japanese colonization of Ezochi, one that weakened Ainu economic autonomy almost entirely. According to most historiographical accounts the conflict is

\footnotetext{
${ }^{33}$ David L. Howell, "Ainu Ethnicity and the Boundaries of the Early Modern Japanese State," Past and Present 142 (February 1994), 85-87.

${ }^{34}$ Walker, Conquest, 74-87, 178-182.
} 
often explained as an ethnic struggle between the Ainu and Japanese settlers, and to some extent this is true. Shakushain's forces did attack and destroy all but two of the Japanese settlements on the island before his assassination by Japanese forces posing as negotiators. However, the conflict was rooted in localized disputes over access to Japanese trade, and it should be noted that Matsumae forces were supported militarily by numerous Ainu chieftains, notably those located closest to Wajinchi, while a number of Japanese gold prospectors and hawk hunters who had ventured and settled deep in Ainu territory, some forming deep ties to Ainu communities through marriage, fought alongside Shakushain's forces. ${ }^{35}$ Although there is evidence that Ainu society at the time was undergoing a process of political and cultural consolidation in response to the encroachment of Japanese settlements, we must remember that, ultimately, Ainu communities were independent politically, alliances were fluid, and their cultural practices were neither uniform nor static. Thus, inter-Ainu warfare remained common during the early colonial period. Furthermore, some Ainu communities had been allies of the Matsumae family for nearly a century having fought with them "in Tohoku to put down the rebellion of Kunohe Masazane against Hideyoshi in 1591." "36 The nature of political relations on Ezochi were indeed complex.

\footnotetext{
${ }^{35}$ Takakura Shinichirō, The Ainu of Northern Japan: A Study of Conquest and Acculturation (Philadelphia: American Philosophical Society, 1960), 50-51. In the early seventeenth century the discovery of gold in Ezochi brought thousands of Wajin miners there. The hunting of hawks was a specialized occupation and Matsumae authorities required live hawks, as they were used as tribute for the Tokugawa regime and were sought after by many high-ranking samurai. Hunting with hawks had been a popular form of recreation in elite samurai circles for centuries.

${ }^{36}$ Matsumae-chō shi, ed. Matsumae-chō shi henshū shitsu, vol. 1 (1975), 346 at Northern Studies Collection, Hokkaido University Library and Richard Siddle, Race, Resistance and the Ainu of Japan (New York: Routledge, 1996), 35.
} 
One of the primary causes of the Shakushain's War lay in the activities of large trading houses from the Japanese mainland, such as the Ryōhamagumi and Yawatagumi that set up branch offices in Wajinchi and invested significantly in fishery operations near these settlements. During the Edo period, many samurai families borrowed from trading companies and fell deeply into debt, and this may have been the case with the Matsumae clan and its retainers. In any event, these merchant houses gained a direct foothold in the financing and operation of Wajinchi commercial fisheries. ${ }^{37}$ Because of the Matsumae's stranglehold on Ainu trade-Ainu became dependent on foodstuffs, clothing, and iron tools from the Japanese mainland by this time and could only acquire them through approved Matsumae trading stations - as well as the effects of environmental destruction, disease, and the growing influence of merchant houses, Ainu communities became enmeshed in the commercial fishing economy as the prices of essential commodities rose. Previously, the Ainu of southern Ezochi were able to trade directly with merchants in Tohoku, and scholars like Kaiho Mineo believe Shakushain intended to reopen banned Ainu trading networks through armed struggle. In the aftermath, the problems that had led to the conflict intensified. Ainu communities sank deeper into poverty and faced epidemics on an unprecedented scale. Commercial fishery operations expanded as agricultural production on the Japanese mainland experienced exponential growth with the Ainu who labored in "slave-like conditions" providing as much as $50 \%$ of the herring fertilizer used in the wet-rice growing regions of Western Japan.

Many of the Japanese accounts of Ezo during this time comment on the exotic features and perceived obsequiousness of the Ainu. However, these accounts must be

${ }^{37}$ Kaiho Mineo, Kinsei no Hokkaido (Tokyo: Kyōikusha, 1979), 101-102. 
viewed critically not only in terms of bias but also with proper contextualization, meaning we need to view them while bearing in mind the nature of settler colonialism in that it "is not simply a military quest, legal process, or government-led project" but instead "a complex cultural system" with an "underpinning ideology and the execution of policies backed by those ideological beliefs. ${ }^{, 38}$ Or, to put it more simply, in the words of Patrick Wolfe, the Japanese colonization of Ainu Mosir was "a structure not an event."39 Although the Ainu were not without agency and did in fact actively and sometimes violently resist colonial subjugation, over time they became further enmeshed in the web of political, social, economic, epidemiological, and environmental destruction wrought on their communities.

While the Ainu were facing unprecedented communal destruction, on the Japanese mainland the Pax Tokugawa had taken effect, and the endemic warfare that marked previous eras ceased. The new government focused its energies on agricultural and infrastructure development, which promoted the growth of sizable urban populations, bustling commerce, and extensive knowledge and cultural production rooted in the discourse of travel. Just as in Europe and the Americas, the advent of print culture and curiosity about the wider world gave rise to a growing body of travel literature, a popular and enduring medium that provided entertainment and information-albeit often conflicted and dubious—about far off places beyond most peoples' imagining. Even writers who did not travel to distant locations themselves were motivated to compose

\footnotetext{
${ }^{38}$ Michele M. Mason and Helen J.S. Lee, "Introduction," in Reading Colonial Japan: Text, Context, and Critique, ed. Michele M. Mason and Helen J.S. Lee (Stanford: Stanford University Press, 2012), 16.

${ }^{39}$ Patrick Wolfe, "Settler Colonialism and the Elimination of the Native," Journal of Genocide Research 8:4 (2006), 388.
} 
works about them through a combination of personal interest and the possibility of profit and prestige. Just as the fantastical tales of Marco Polo, Hernán Cortés, and John Smith galvanized audiences in Europe so, too, did the popular travel-themed works of Matsuo Bashō, Kaibara Ekken, and Kumazawa Banzan captivate the Japanese literate public. ${ }^{40}$ One of the first works about Ezochi that gained popularity in Japan was Arai Hakuseki's Ezo-shi (Ezo Gazetteer) ${ }^{41}$ written in 1720. Arai, a shogunal advisor-cumscholar, had himself never traveled to Ezo though he was able to compose his manuscript based on materials collected in the shogunal library in Edo. Sasaki Toshikazu mentions that although some of the book's content is problematic in that it contains various ethnographic distortions (subjects with excessive hairiness and unfounded claims of Ainu cultural habits, for example), the images "are a convincing portrayal of Ainu formal dress, which utilized many imported goods as luxury and prestige items. ${ }^{.42}$ Another wellknown example of paintings composed in a similar style are those by Kakizaki Hakyō created decades later. These paintings depict twelve southern Ainu chieftains loyal to the Matsumae. ${ }^{43}$ The subjects are seen dressed in fine silk robes acquired from the Santan trade with northeast continental Asia and thick animal furs. Some sit still in a regal position, others brandish weapons, such as hunting bows and spears, while still others are shown walking pet dogs and bear cubs. Like the Ezo-shi, the Kakizaki portraits depict the

\footnotetext{
${ }^{40}$ See Marcia Yonemoto, Mapping Early Modern Japan: State, Place, and Culture in the Tokugawa Period1603-1868 (Berkeley: University of California Press, 2003), Constantine Nomikos Vaporis, Breaking Barriers: Travel and the State in Early Modern Japan (Cambridge: Harvard University Press, 1995), Laura Nenzi, Excursions in Identity: Travel and the Intersection of Place, Gender, and Status in Edo Japan (Honolulu: University of Hawai'i Press, 2008).

${ }^{41}$ Arai Hakuseki, Ezo-shi [1720], Northern Studies Collection, Hokkaido University Library.

${ }^{42}$ Sasaki, "Ainu-e," 82.

${ }^{43}$ Several of these are today scattered at museums around the world, but their images are easily accessed online.
} 
formal fashion of the Ainu elite accurately though the subjects are clearly painted in a way that exaggerates their physical and cultural differences from the Wajin. ${ }^{44}$ This was, of course, intentional and although the wealthy chieftains are not representative of the average Ainu, the paintings clearly demonstrate some of the power dynamics of Japanese colonialism, and by extension how power and position in the Tokugawa system were marked by ritual and outward appearance.

Much has been written on the role of physical appearance as a strict marker of status in the Edo period, as sumptuary laws dictating hair and clothing styles were used to regulate relations between the various classes of commoners, officials, warriors, merchants, and outsiders (hinin, eta, etc.). One well-known example is the edict preventing wealthy merchants from purchasing and wearing fine silk garments meant for those of the elite samurai class, many of whom could not even afford these fashions on their meager stipends. Similar principles were put into practice to govern relations between the bakufu ${ }^{45}$ and the Ainu and Ryūkyūan peoples on the northern and southern peripheries of the Japanese state. Ainu were made to partake in annual ceremonies that they called 'uimam' at the Matsumae lord's quarters where they were expected to don the exquisite robes, giant furs, and traditional Ainu weapons depicted in the Kakizaki portraits. The dogs and bear cubs added an additional exotic flair to the ceremonies, as well as to the paintings of them. It should be noted that to the Wajin 'uimam' was seen as a tributary ritual representing the subordination of a foreign people, while the word in

\footnotetext{
${ }^{44}$ Ezo-shima kikan (Curious Sights of Ezo Island), written several decades later, is considered by comparison a far more accurate source in is visual and literary depictions of Ainu life. Murakami Shimanojo, Ezo-shima kikan [1799], Waseda University Library. Due to its popularity, this work has been reproduced many times and can be found online in various digital archives.

${ }^{45}$ An alternative word for Shogunate; it means military "tent" government.
} 
Ainu simply means 'trade.' The Ryūkyū elite were also made to perform elaborate annual ceremonies in the form of pilgrimages to Edo similar to those of Japanese daimyo with one notable distinction: by law Ryūkyūan visitors had to wear Chinese robes, headgear, and carry Chinese weaponry. Morris-Suzuki writes: "The whole symbolic significance of these tribute payments rested on the fact that they could be seen as representing the submission of foreign peoples to Japanese power. So every opportunity was taken to ensure that the ritual of the tribute mission emphasized the exotic appearance of the Ryūkyūan and Ainu emissaries. ${ }^{, 46}$

This system extended far beyond the experiences of the Ezochi elite so that even common Ainu were forbidden from wearing Japanese clothing and hairstyles, trimming their hair and beards in the case of men, abstaining from and/or covering tattoos in the case of women, learning Japanese, and practicing agriculture. ${ }^{47}$ The belief was that crossing these stark and often exaggerated cultural boundaries would bring about social disorder. One reason for these practices is that they were emblematic of the $k a-i$ shis $\bar{o}$ ideology regarding civilized $(k y \bar{o} k a)$ and barbarian $(i t e k i)$ peoples in Confucian diplomacy, principles that came to play an even larger role in Tokugawa statecraft than in previous regimes. Ronald Toby points out an interesting secondary reason for this. He explains that after the Japanese came into contact with Europeans in the sixteenth century they were inundated by a wave of knowledge concerning new places and peoples of the

\footnotetext{
${ }^{46}$ Tessa Morris-Suzuki, "A Descent into the Past: The Frontier in the Construction of Japanese Identity," in Multicultural Japan: Palaeolithic to Postmodern, ed. Donald Denoon et al (Cambridge: Cambridge University Press, 1996), 83-84. See also Oguma Eiji, The Boundaries of 'the Japanese': Korea, Taiwan and the Ainu 1868-1945, vol. 2, trans. Leonie R. Strickland (Melbourne: Trans Pacific Press, 2017), 16-21.

${ }^{47}$ There are accounts of Ainu individuals who did not follow these rules. For example, one elite Ainu named Iwanosuke lived in a Wajin village and dressed in fashionable Japanese clothes, spoke fluent Japanese, and wore a Japanese-style top-knot. His example is discussed further in chapter 3.
} 
world. The spread of bankoku (lit. 10,000 lands; myriad realms) in art and literature completely altered the Japanese cosmology and worldview; previously, there had been three known areas of the world (Japan, China and its continental environs, and India). Toby contends that this resulted in "a compulsion to distinguish oneself - collectivelyfrom those [who] felt most uncomfortably proximate and similar," a process that allowed "proximate Others," such as Ainu, Koreans, and Ryūkyūans, to be "rendered consistently

distinct and visible in Japanese visible imaginings for the first time., ${ }^{, 48}$ Toby's assertion is interesting and perhaps correct; however, it would seem that the evolution of the Japanese-Ainu colonial relationship, growing economic ties between Ezo and the Japanese mainland, and new conceptions of geography and space within Japan proper also played a prominent role in this paradigmatic shift.

\section{Borders and Biopolitics in the Late Edo Period}

In the last quarter of the eighteenth century the Tokugawa government was faced with its first perceived international threat. This began in 1771, when the Hungarian military adventurer Maurice Benyovsky sailed into several Japanese ports in a stolen ship after escaping from a Russian prison camp in Kamchatka. During his peregrinations along the Japanese coast, he posed as an Austrian naval commander and sent letters in German addressed to the Dutch in Nagasaki warning of a pending Russian invasion of the Japanese islands. The letters were intercepted and brought to the capital where they were translated, and although we now know that Benyovsky's claims were outright

\footnotetext{
${ }^{48}$ Ronald P. Toby, “Imagining and Imaging ‘Anthropos' in Early-Modern Japan,” Visual Anthropology Review 14:1 (1998), 21-22.
} 
fabrications, at the time they caused quite a stir. Several shogunal officials were sent to Nagasaki and Ezochi to gather information on the pending threat.

By chance, Kudō Heisuke, a doctor studying rangaku in Nagasaki, heard about the incident and conducted his own investigation whereby, probably through Dutch informants, he discovered that Russia had sent crews to the Kurile Islands to build relationships with the Ainu living there. In fact, since the 1740s, Russia had been establishing trading posts and churches in the northern Kuriles and some of the small Ainu communities living there had adopted Russian names and Western dress, and had converted to Orthodox Christianity, but there was no Russian military presence in the region. ${ }^{49}$ However, the perception of a northern threat came to a head once again in 1792 , when an official from the court of Catherine II entered the port of Nemuro in eastern Ezochi and appealed to the bakufu to enter into trade relations. The Shogun's officials refused and the Russian vessel left without incident; however, the event caused great concern over the future security of Japan's northern border. ${ }^{50}$ Honda Toshiaki, a respected scholar, recommended that the bakufu bring the whole of Ezochi under its direct control and create assimilation programs for the Ainu inhabitants. ${ }^{51}$ The Shogunate eventually enacted new policies in this mold to counter what they saw as a definitive threat to their interest in Wajinchi.

Wajinchi was brought under the direct administrative control of the shogunate in 1799 , in a process that set off several major cartographic expeditions to map Ezo and the

\footnotetext{
${ }^{49}$ Donald Keene, The Japanese Discovery of Europe: Honda Toshiaki and Other Discovers 1720-1798 (Stanford: Standford University Press, 1969), 41-47.

${ }^{50}$ Conrad Totman, Early Modern Japan (Berkeley: University of California Press, 1993), 484-485.

${ }^{51}$ Keene, Discovery, 142-152 and Morris-Suzuki, Re-Inventing, 21-22.
} 
entire Japanese coastline, not just for the purpose of military defense, but also as a means to communicate the extent of Japanese territorial borders to Western powers who used the same methods of conceptualizing national space. Brett Walker explains how this process had enormous ramifications for the Ainu, as "the 'land' mapped cartographically became disassociated from the 'people' documented ethnographically; through separate categories of scientific knowledge the land was emptied, placed on a grid for all cartographically literate people to read, and then made available to policymakers in Edo. ${ }^{, 52}$ In short, these explorers departed from the previous tradition of combining maps and illustrations alongside ethnographic details of the people they encountered. They instead drew separate cartographic projections with no mention of the peoples there, and wrote independent and highly detailed ethnographic travelogues, such as Mamiya Rinzō's Kitaezo zuesetsu (Illustrated Explanation of Northern Ezo). Through the act of mapmaking the explorers Mamiya Rinzō, Matsuda Denjirō, Inō Tadataka, and Mogami Tokunai ${ }^{53}$ extended the Japanese frontier both geographically and conceptually to the Kurile Islands and Sakhalin, while Ezo (Hokkaido) was reconfigured as a natural extension of Japanese territory. These state-sponsored mapmaking projects changed the social position of the Ainu within the Japanese state from a foreign "barbarian" people to an ambiguous one, not quite foreign but not yet Japanese.

\footnotetext{
${ }^{52}$ Brett L. Walker, "Mamiya Rinzō and the Japanese Exploration of Sakhalin Island: Cartography and Empire," Journal of Historical Geography 33 (2007), 286.

${ }^{53}$ In a twist of irony, Mamiya Rinzō was something of an exploration apprentice to Murakami Shinanojō, the author of Ezo-shi kikan who had spent several years living and traveling among the Ainu, and Mogami Tokunai was a student of Honda Toshiaki, the scholar who first argued to the shogun in favor of the total annexation of Ezo.
} 
The process of bringing the Ainu into the Japanese fold required detailed information on their present conditions, and Mogami Tokunai wrote extensively on this issue in his 1791 account Ezokoku füzoku ninjō no sata (Report on the Customs and Character of Ezo). Mogami reported on the worsening conditions of Ainu labor and the rampant sexual abuse of Ainu women by Japanese fishery supervisors, as well as the lack of medicine and medical care. ${ }^{54}$ By this point the Japanese government could not offer significant medical assistance, but the prevailing notion was that if Ainu changed their customs and conformed to Japanese cultural practices then their situation would improve. In several areas, Japanese officials offered material rewards to Ainu individuals who agreed to shave their beards and dress in Japanese clothing, behavior that had been strictly prohibited by the Matsumae regime just a few years earlier. However, the Tokugawa government simply lacked the will and the resources to promote assimilation on a large scale, and it was opposed by most Ainu who had no interest in shedding their own culture, as well as the Matsumae and fishery supervisors for whom "the idea of assimilation was incompatible with [their] deeply prejudicial attitudes. ${ }^{, 55}$ Ultimately, the assimilation project was abandoned and the Tokugawa regime transferred the administrative control of Wajinchi back to the Matsumae clan in 1821, after which the previous cultural prohibitions against the Ainu behaving and dressing as Japanese were reinstated.

Ironically, although the bakufu authorities were unable to provide high levels of medical care to Ainu communities during this period, the state-sponsored maps that were

\footnotetext{
${ }^{54}$ Ezokoku füzoku ninjō no sata [1791] in Takakura Shinichiro, ed. Nihon shomin seikatsu shiryō shūsei, vol. 4 (Tokyo: Sanichi Shobō, 1969), 460.

${ }^{55}$ Siddle, Race, 41.
} 
created were eventually made public, and the information they contained allowed many doctors and medical scholars to travel to Ezo in search of rare materia medica. Federico Marcon has detailed the rise of honzoggaku, "a field of study of Chinese origins ancillary to medicine, devoted to the pharmacological properties of minerals, plants, and animals. ${ }^{, 56}$ Honzōgaku was a product of the proliferation of Chinese and later Western texts on biology and medicine that occurred during the mid-to-late Edo period. ${ }^{57}$ Luminaries of the time, like Kaibara Ekken, traveled far and wide in Japan cataloging the various plants and animals they encountered. By the mid eighteenth century, honzōgaku scholars also were employed by the state to assist with cadastral surveys and agricultural reform, aiding in the cultivation of new crops, such as sugarcane and sweet potatoes, as well as medicinal gardens ${ }^{58}$ These new agricultural policies were a response to famines in the countryside in the preceding decades. After taking direct control of Ezo in 1799, the Shogunate made the surveying of the island's plants, animals, and medicines used by the Ainu a part of official colonial policy ${ }^{59}$ These actions fit within Londa Schiebinger's concept of "bioprospecting," the search for useful plants and animal products by colonial powers in colonial territories. ${ }^{60}$ Not only do these activities facilitate a deeper penetration of colonial territory, they also appropriate indigenous knowledge while simultaneously denying the existence of the knowledge systems from which these discoveries derived. Indigenous peoples were rarely credited with the discovery and use of medicinal plants

\footnotetext{
${ }^{56}$ Federico Marcon, The Knowledge of Nature and the Nature of Knowledge in Early Modern Japan (Chicago: The University of Chicago Press, 2015), x.

${ }^{57}$ Shogun Tokugawa Yoshimune himself was a student of honzōgaku, as were many daimyo and highranking samurai. Yoshimune was responsible for relaxing the ban on Western books in 1720 .

${ }^{58}$ Marcon, Knowledge, 115-121.

${ }^{59}$ Walker, Conquest, 194-197.

${ }^{60}$ Londa Schiebinger, Plants and Empire: Colonial Bioprospecting in the Atlantic World (Cambridge: Harvard University Press, 2004).
} 
because indigenous knowledge did not fit within the schematic models of knowledge production and taxonomy employed by their colonizers.

The voyages of Japan's Edo-period cartographers and naturalists are a distinct example of bioprospecting, as Ainu guides and crews were indispensable to the success of these ventures. In the case of pharmaceuticals, the Ainu had long used items like kuma no $i$ (bear gallbladder), eburiko, (Fomitopsis officinalis, a species of fungus), ikema (Cynanchum caudatum), and okurikankiri (Cambariodes joponicus, a shellfish product) among others that Japanese doctors prized for their healing properties. Bear gallbladders and eburiko became particularly valuable in elite circles and were exchanged as gifts between domanial lords and the shogun. ${ }^{61}$ Studies of honzōgaku have recently come into vogue as it is believed to represent a distinctly 'Japanese' systematic understanding and classification of nature occurring centuries before the adoption of Western science in the Meiji Period. This view is problematic on numerous fronts, however. Firstly, honzōgaku from its earliest days was rooted in knowledge of Chinese medicine and, as discussed earlier, began to take root in Japan only after the proliferation of Chinese texts in the middle part of Edo Period. ${ }^{62}$ The Pax Tokugawa ushered in a prolonged duration of peace wherein many elite samurai found new callings in the pursuit of knowledge and scholarship, and familiarity with the Chinese classics and kanpō (Chinese medicine) was held in high esteem. Secondly, especially after the prohibitions against Western scientific texts were relaxed in 1720, rangaku (Dutch Learning) also flourished, and a considerable number of honzōgaku scholars were also doctors who studied the European medical

\footnotetext{
${ }^{61}$ Walker, Conquest, 194-197.

${ }^{62}$ See Benjamin A. Elman, "Sinophiles and Sinophobes in Tokugawa Japan: Politics, Classicism, and Medicine During the Eighteenth Century," East Asian Science, Technology and Society 2:1 (2008).
} 
knowledge brought to Dejima by Dutch traders there. There is little doubt that most scholars and members of the Japanese elite during this period were at least somewhat familiar with Western models of biological classification. Finally, just as with scientific discoveries in the West, Japanese honzōgaku scholars who traveled to Ezo were merely reinterpreting extant indigenous knowledge and transmuting it into taxonomical modes with which they were more familiar. In short, the development of honzōgaku was a dynamic and syncretic process that constituted a new means of cataloging and communicating knowledge of the natural world discovered through alternate epistemiological systems of thought.

Another factor that increased the Japanese penetration of Ainu lands during the Edo period was the state-sponsored administration of Jennerian vaccinations. As we have seen, from the period of initial Japanese settlement on Ezochi numerous waves of epidemic disease (smallpox, measles, tuberculosis, etc.) ravaged Ainu communities. Ann Jannetta Bownman, a pioneer of early modern Japanese epidemiology studies, observed that throughout the Edo Period smallpox was the leading cause of death among Japanese people, perhaps killing as much as $10 \%$ of the population. Ainu communities fared far worse due to the late introduction of these pathogens into their disease ecology. ${ }^{63}$ This condition was aggravated by the growing influx of Japanese immigrants into Wajinchi, as well as the crowded conditions of commercial fisheries where Ainu came to be employed in greater numbers.

\footnotetext{
${ }^{63}$ Ann Bowman Jannetta, "Disease of the Early Modern Period in Japan," in The Cambridge World History of Human Disease, ed. Kenneth F. Kiple (Cambridge: Cambridge University Press, 1993), 385-387. See also Ann Bowman Jannetta, Epidemics and Mortality in Early Modern Japan (Princeton: Princeton University Press, 1987).
} 
By the 1830s, the expansion of the fishery industry attracted tens of thousands of Japanese immigrants, and by the final years of the shogunate there were about 60,000 Japanese residents in Wajinchi. While the Wajin population increased, the Ainu faced a pronounced demographic collapse, a fate they understood as the wrath of payoka kamuy (lit. "the punishing god) who took the form of the terrifying smallpox outbreaks. A government census in 1807 estimated the population of Ainu at 26,256, while a later census conducted in 1854 showed a population reduction to 15,810 , a decline of $32 \%{ }^{64}$ One prominent medical observer sent to monitor events in Ezochi on behalf of the bakufu observed that the Ainu populations of Akkeshi and Nemuro in eastern Ezochi (historically a center of Ainu resistance) had experienced declines of $75 \%$ and $57 \%$ respectively during the first half of the nineteenth century. ${ }^{65}$ This same author also remarked on the rise of prostitution by both Ainu and Japanese women in Hakodate and the rampant sexual violence perpetrated against Ainu women by Japanese men. The author attributes these activities to the substantial rates of syphilis that afflicted Ainu communities in the areas surrounding Hakodate. Syphilis has been recognized by historians as having had a detrimental effect on indigenous populations, due to its potential to attenuate indigenous peoples' ability to reproduce and counter their demographic decline. ${ }^{66}$

\footnotetext{
${ }^{64}$ Shirayama Tomomasa, Matsumae Ezo-chi basho ukeoi seido no kenkyū (Tokyo: Genandō shoten, 1971), $35-36$.

${ }^{65}$ Matsuura Takeshirō, "Nosappu nisshi" and "Shiretokko nisshi" [1858] in Matsuura Takeshirō kikōshū, vol. 3, ed. Yoshida Takezō (Tokyo: Fūzanbō, 1977), 424, 457.

${ }^{66}$ See Alfred Crosby, Ecological Imperialism: The Biological Expansion of Europe, 900-1900 (Cambridge: Cambridge University Press, 1986).
} 
The plight of the Ainu became a rallying cry in the mid nineteenth century among those in the Tokugawa administration who once again feared European, and now American, encroachment on their northern border. Yet, as this chapter has demonstrated, it was not solely the fear of Western powers that drove the bakufu's Ezo policies, but a paradigmatic shift in their thinking about the geographical peripheries of the nation, as well as a reconceptualization of the relations with the peoples living there. The Shogunate had once again wrenched control of Wajinchi from the Matsumae clan in 1854, placing its northern periphery directly within its administrative control. In response to the Ainu's demographic crisis, the Shogunate commenced the 1857 Jennerian vaccination project in Ezochi. Edward Jenner, the celebrated English physician, had successfully tested his smallpox vaccine in 1796, which required transferring the fluid from a live cowpox pustule and injecting it into surface levels of the skin. Word of its success spread quickly around the globe, and although many students of rangaku and honzōgaku in Japan had been aware of the vaccine for decades and had even tried several times to acquire it, an unspoiled live vaccine did not enter Japan until $1849 .{ }^{67}$ Initially, the administration of the vaccine was arranged and conducted by private physicians in Nagasaki who treated children arriving at their clinics from domains in Kyushu and Southern Honshu. After the treatment, the children returned to their homes with the pocks on their arms that served as a source for the vaccine for local doctors who then treated patients in their own domains.

\footnotetext{
${ }^{67}$ Ann Jannetta, "Jennerian Vaccination and the Creation of a National Public Health Agenda in Japan, 1850 - 1900," Bulletin of the History of Medicine 83:1 (2009),125-129. Jannetta explains that China's discovery of the smallpox vaccine preceded Europe's though they used a different technique for storing it: instead of storing in a cow lymph they stored it as a scab. The live cow lymph could not survive the long sea voyage to Japanese territory, so honzōgaku scholars who were familiar with the Chinese method in Chinese medical texts requested Dutch doctors to ship it as a scab from Batavia. Their efforts were successful.
} 
Jannetta remarks that "within six months vaccination was being performed in clinics throughout the entire length of the Japanese Islands. ${ }^{, 68}$ The vaccination continued to be sponsored privately until 1857, when a substantial epidemic broke out in Ezochi after which point the shogunate instituted a state-sponsored medical regime with vaccination clinics constructed throughout the entire country.

As we can see, the 1857 vaccination project designed to treat the people of Ezochi was an extension of the first modern national public health agenda in Japanese history. In the fourth month of 1857, the Shogunate dispatched six Edo physicians, led by Kuwata Ryūsai and Fukase Yōshun, to Ezochi. Fukase was himself a native of Hakodate though he had traveled to the mainland for medical study and formed a practice there. The physicians were dispatched to eastern Ezo where Wajin were few in number and were warned that the Ainu in this region might refuse treatment, and indeed, in his personal notes Kuwata records that upon their arrival Ainu from various communities had escaped to the nearby mountains to avoid encountering the itinerant medical team. When they went to the local fisheries they were treated with hostility by merchants and supervisors for disturbing their operations by scaring off their laborers who refused to leave their mountain hideouts. ${ }^{69}$ After their initial failure, the doctors were advised by a local observer to use 'polite persuasion' (konyu sōrō) when interacting with the Ainu.

A year later Kuwata returned to Edo and was replaced by Inoue Genchō, one of the lower-ranking physicians of the group. Inoue discovered in talks with Ainu elders in Nemuro that the Ainu might agree to vaccination if they were, again, "politely

\footnotetext{
${ }^{68}$ Ibid. 129.

${ }^{69}$ Kuwata Ryūsai, "Ezo shutō kiji" [1857] as cited in Brett L. Walker, "The Early Modern Japanese State and Ainu Vaccinations: Redefining the Body Politic 1799-1868," Past \& Present 163 (1999), 141-148.
} 
persuaded." In fact, he discovered that many of the local Ainu had been told to refuse vaccination by their supervisors ahead of the physicians' arrival because they were concerned about delays and disruptions that might occur if some of the Ainu agreed. Shortly after discussions with the elders, several Ainu women from Honioi arrived and requested to be vaccinated; after the first round of vaccines were administered more women from the village appeared, then nearly the entire village, followed later by people from the surrounding villages. Matsuura Takeshirō, an important Japanese observer, wrote of an experience with one Ainu man named Tomiante who arrived at the makeshift clinic with his sick son lamenting that "of [his] five children four have died" and declaring boldy "this thing called a 'vaccination' of which the Ainu and fishery managers are so afraid, I would like to try it.,"70

As the accounts above indicate, the Ainu elders' plea for "polite persuasion" meant that the physicians would be better served if they recognized their social position and respected local Ainu customs when trying to administer the vaccines. Walker notes: "From this point forward, physicians used Ainu ceremonial greetings such as the omusha to tap into local Ainu social hierarchies and gain consent for the procedure." ${ }^{, 71}$ The doctors also used Ainu gift-giving practices at the clinics offering ikor (treasures; imports from the Japanese mainland) like silk, cotton, clothing, lacquerware, rice, and sake to those who consented to vaccination. Of course, the physicians also ordered Japanese troops to venture into the mountains and round up Ainu hiding there so that they, too, could receive treatment. Furthermore, as the vaccination project was being carried out

\footnotetext{
${ }^{70}$ Matsuura Takeshirō, "Kinsei Ezo jinbutsu shi” [1858], in Matsuura Takeshirō kikōshū, ed. Yoshida Takezō (Tokyo: Fuzanbō, 1975), 169-170.

${ }^{71}$ Walker, "Early Modern," 151.
} 
shogunal officials in Ezo reestablished the assimilation programs that had been abandoned decades prior, as they once again offered material rewards to Ainu men who agreed to shave their beards, wear Japanese clothes, and take Japanese names. Japanese officials justified such actions by invoking buika, a Confucian precept that emphasized the responsibility of rulers for the social welfare of their subjects. ${ }^{72}$ Tokugawa officials recognized the Ainu's demographic decline as being rooted in disease and poverty, though they believed these factors stemmed from Ainu "barbarism," or the Ainu's cultural differences from the Japanese.

By the end of the year, the physicians had vaccinated over 5,000 people in the area, and by the time the project had concluded an average of $60 \%$ of the Ainu in local communities had received the Jennerian vaccine. ${ }^{73}$ Although ultimately a humanitarian endeavor, the vaccination project also served as a way to project the power and influence of the Tokugawa state farther northward and directly onto Ainu bodies. We can view this as a biopolitical exercise by the Tokugawa state to engender a new relationship with their Ainu subjects, one marked by greater state control in Ainu affairs. Foucault, the originator of the concept of "biopolitics," argued that European states since the early modern period had made issues of health and sanitation into an essential area of government policy, a way to form deeper and more enduring ties with the entirety of their domestic populations. ${ }^{74}$ These strategies were employed in the colonies as well, as the improvement in the health and welfare of colonized peoples played a prominent role in

\footnotetext{
${ }^{72}$ Howell, Geographies, 140-142.

73 Ibid. 159.

${ }^{74}$ See Michel Foucault, The Birth of Biopolitics: Lectures at the Collège De France 1978-1979, ed. Michel Senellart, trans. Graham Burchell (New York: Palgrave MacMillan, 2008).
} 
the legitimization of the colonial project, perhaps even greater than proselytizing efforts of missionaries, though these often worked in tandem. Though much of the scholarship on biopolitics has tended to privilege analyses of European imperialism, we need bear in mind that Europe was not unique in the world in its colonial ambitions; Japan, even in the premodern period, shared these desires and acted on them. Clearly, the Tokugawa government's 1857 vaccination project fits the Foucauldian criteria as an exercise in biopolitics, shaped as it was by complex colonial power dynamics, concerns over public health, and its own distinct "civilizing mission."

\section{Conclusion: Japanese Restoration and the Deconstruction of Ainu Mosir}

The Vaccination project of 1857 was taking place during a time of intense political turmoil and transition in Japan. Just four years prior, the Tokugawa government was shaken by the arrival of American warships in Edo bay demanding that Japan enter into trade relations with the United States. The Shogunate recognized the technological superiority of the Europeans and Americans and acquiesced to trade demands with various Western nations. In 1868, the Tokugawa government was disbanded and the Satchō alliance formed a new government with the Meiji emperor at its head. These vast changes had repercussions for the country at every level of society and impacted all of its people, including the Ainu.

In 1869, the Japanese government officially annexed Ezochi renaming it Hokkaido (Northern Sea Circuit) and later made it into a prefecture of Japan. The economic activities, violence, and epidemiological crises that wrought havoc on Ainu Mosir in the early modern period had severely weakened Ainu resistance. Moreover, the 
art and travel accounts, ethnographic and naturalist studies, cartographic surveys, and public health efforts conducted in the preceding centuries had continually reconfigured the colonial relationship between Ainu and Japanese. Marcia Yonemoto argues that Japanese in the early modern period experienced "a revolution in the understanding and representation of space."75 The illustrated travel narratives, ethnographic and medical treatises, state-directed mapmaking and biopolitical endeavors accumulated over the preceding centuries had dramatically altered the vernacular understanding of national space in the minds of the Japanese public and helped spur the emergence of a nascent national identity.

Western economic advisors, scientists, and researchers were invited to Japan in order to instruct the population on the ways of modernity. Slogans such as Fukoku kyōhei (Rich nation, strong military) and Bunmei kaika (Civilization and Enlightenment) became the ethos of a new era. Other ideas proliferated, too. The work of Herbert Spencer and its assertions of epic racial struggle and the "survival of the fittest" found in Meiji Japan one of its most receptive audiences. Malthusian notions of lebensraum (living space) informed Meiji oligarchs that the Japanese mainland was overpopulated, so emigration was encouraged on a mass scale, to Hawaii, the United States, and South America, but most of all to Ainu Mosir-Hokkaido.

The promotion of Hokkaido as a living space was based on the idea that it was vast, empty, nearly uninhabited. The anxieties of 'pioneers' who settled Japan's northern 'frontier' found expression in the media and popular literature of the time. One such

\footnotetext{
${ }^{75}$ Marcia Yonemoto, “The 'Spatial Vernacular' in Tokugawa Maps," The Journal of Asian Studies 59:3 (2000), 647-648.
} 
example can be seen in Kunikida Doppo's 1902 novel Sorachigawa no kishibe (The Shores of the Sorachi River) in which the protagonist journeys to purchase a large plot of land along the Sorachi River. Disenchanted upon leaving the burgeoning urban environs of Sapporo for the deep Hokkaido interior he remarks: "Where is society? Where is the 'history' that humans are so proud to pass on? Here people are only creatures of 'survival' and feel only that they are at the mercy of one breath of nature."76 The character leaves Hokkaido never to return. There is, of course, no mention of the fact that during this time entire Ainu communities were being forcibly relocated from their villages along Hokkaido's rivers to make way for incoming farmers from the mainland, like the protagonist himself.

The academic community also played a significant role in redefining space and identity in Hokkaido. According to the racialist logic of nineteenth-century social science discourse, the Ainu were labeled a "dying race," one "that [had] struggled and lost" ${ }^{\text {"77 }}$ in their competition with the Japanese. Nitobe Inazō, a famed scholar and statesman of the period, wrote of Hokkaido and the Ainu in a promotional booklet for the 1893 World's Columbian Exposition in Chicago: "the northern islands of Japan, vaguely called Yezo [sic], were for centuries a terra incognita among people; all that was told about it...was that it was the abode of a barbarian folk known as the Ainu, and that it was a dreary waste of snow and ice. ${ }^{.78}$ As can be seen from these examples, the Ainu now had to contend

\footnotetext{
${ }^{76}$ Kunikida Doppo, "The Shores of the Sorachi River" [1902], trans. Michelle M. Mason, in Reading Colonial Japan: Text, Context, and Critique, ed. Michele M. Mason and Helen J.S. Lee (Stanford: Stanford University Press, 2012), 60.

${ }^{77}$ Again, taken from Frederick Starr, The Ainu Group at the Saint Louis Exposition (Chicago: The Open Court Publishing Company, 1904), 110.

${ }^{78}$ Nitobe Inazō, The Imperial Agricultural College of Sapporo, Japan (Sapporo: Imperial College of Agriculture, 1893), 1.
} 
with a new colonial ideology in the Meiji period, one that denied their status as full members of the human family and was attempting to write them out of existence. Alongside other indigenous groups, the Ainu were transformed through the logic of colonialism into a "vanishing people" and paraded around the world as objects of curiosity and academic scrutiny. The land of Ainu Mosir became, in the eyes of researchers, nothing more than a graveyard, a repository of anthropological data and human remains used to test their theories of humanity's past. And Hokkaido, represented the promise of a grand Japanese future, an island of unbound natural resources and industrial potential upon which the artifices and architecture of the modern Japanese nation were constructed. 


\section{Chapter 2}

Pseudoscience and Sacrilege:

Grave-Digging, Anthropometry, and the Complex Racialization of Japan

On July 5th, 1888, Koganei Yoshikiyo (1859-1944), a twenty-nine-year-old

medical professor at Tokyo Imperial University, departed Tokyo harbor for the northern island of Hokkaido. After three days at sea he arrived at the port of Hakodate - a voyage that just a decade or so prior, before the introduction of steam ships and railways, would have taken far longer. Several days later he had traveled roughly 150 miles to the small city of Otaru where he established his base of operations at a local hospital. According to his 1935 memoir, the purpose of his visit was twofold: "to conduct biometrical investigations on living members of the Aino [sic] race and to collect as many skulls and human remains as possible." 79 It was at this point that Koganei, a German-educated Japanese physician steeped in the scientific racist discourse prevalent in nineteenthcentury Western thought, became one of the founding fathers of the Japanese social sciences.

Craniometry and other forms of anthropometrical analysis had originated in Europe at the dawn of the scientific revolution in the late eighteenth century, and despite the fact that several visiting researchers from Europe and the United States had already

\footnotetext{
${ }^{79}$ Koganei Yoshikiyo, “Aino no jinshugakuteki chōsa no omohide [sic]: Yonjūhachi-nen mae no omohide," [Remembering Ainu Ethnological Surveys: Memories from the Past Forty-Eight Years] Dolmen 4:7 (1935), 54. During and prior to the Meiji period the Ainu were referred to in writing as both "Aino" and "Ainu" in Western and Japanese sources. Koganei explains that the root of this discrepancy lay in the Ainu's own pronunciation with the final syllable falling somewhere between an anglicized "o and u," 64. The "Ainu" spelling became predominant following the advocacy of John Batchelor, an English missionary and amateur researcher who lived among the Ainu for several decades and complained that the term "Aino" was often used pejoratively due to its association with the Japanese term "ainoko," meaning "half-breed." This he claimed was the result of a belief among many Hokkaido Japanese that the Ainu were descended from the coupling of humans and dogs, no doubt a reference to their supposed "excessive hairiness." This notion of the "hairy Ainu" became a popular racist trope within the imaginations of non-Japanese as well.
} 
applied these methods on Ainu and Japanese subjects alike—on both the living and the dead-it appears Koganei was the first leading Japanese academic to do so. As such, his work served as inspiration for later Japanese researchers to follow the path he had laid out in search of the racial origins of the Ainu, and by extension the racial roots and biological inheritance of the nascent Japanese nation.

Tsuboi Shōgorō, a prodigious young graduate student who two years earlier had founded the Tōkyō jinruigakkai (Tokyo Anthropology Society), ${ }^{80}$ also went to Hokkaido in 1888 to conduct his own research on Ainu bodies. Tsuboi had developed his own theories of Ainu and Japanese origins and would go on to garner even more acclaim than Koganei. Within Japanese academic circles of the past, Koganei, Tsuboi, and other such researchers were somewhat lionized, highly regarded for their brilliance and intrepidness, though to the Ainu and many modern-day researchers they appear nothing short of villains, opportunistic and mendacious scholars who eschewed all notions of research ethics in the pursuit of knowledge, save one: To accumulate as much physical data and specimens from the Ainu before they "vanished" from the earth entirely. Until the rise of the global indigenous rights movement in the 1970s their methods had long been standard practice for anthropological researchers across the globe.

Recent studies on nineteenth- and twentieth-century anthropological researchers have revealed the troubling strategies they often employed to gain access to their subjects, the effects of which reverberate today and continue to shock the conscience. In his memoirs, Koganei openly admitted to the regular use of deception in the pursuit of knowledge, such as coaxing many Ainu into participating in his studies by lying to them

\footnotetext{
${ }^{80}$ The name was changed to Nippon jinruigakkai (Anthropology Society of Japan) in 1941.
} 
about how their corporeal data would be used to develop treatments for smallpox, a disease that had decimated Ainu societies for centuries and continued to ravage their communities as recently as the late nineteenth century. ${ }^{81} \mathrm{He}$ also recounts one incident where during a grave excavation his team was confronted by 5 to 6 Ainu whom his team placated by telling them they were simply moving the exhumed remains to another gravesite, not confiscating them for research. They sold the lie by setting up a makeshift altar out of a wooden board upon which they placed sake, sweets, and flowers while pretending to pray for the deceased. ${ }^{82}$ Following this incident, Koganei took special care to avoid such encounters with Ainu mourners by employing lookouts, conducting his digs at night, and by moving discovered remains away from grave sites to nearby rivers to be cleaned and processed away from prying eyes.

Accounts like Koganei's also show the extent to which these research activities were enmeshed in the new social institutions established after the official annexation of Hokkaido in 1869. The Japanese Imperial University (teikoku daigaku) system, especially Hokkaido Imperial University (currently, Hokkaido University), provided safe spaces for scholars to carry out their activities and discuss their ideas and findings, while providing them access to generous research funding. Koganei would return the following year and conduct an even broader survey of Ainu gravesites excavating 166 skulls and 92 skeletons for his research collection. ${ }^{83}$ Government officials and local business leaders played a large role in funding these endeavors and providing logistical support. In

\footnotetext{
${ }^{81}$ Ibid., 57.

${ }^{82}$ Ibid., 56.

${ }^{83}$ Morris Low, "Physical Anthropology in Japan: The Ainu and the Search for the Origins of the Japanese," Current Anthropology 53:5 (2012), 59.
} 
Koganei's case, a network of shop owners, hospital directors, local politicians, and rich landowners not only helped him locate promising sites for excavation, but sometimes actively took part in the digs themselves. Moreover, hospitals and prisons provided researchers with easy access to Ainu subjects, living and dead alike.

In one infamous case in 1934, Kodama Sakuzaemon, the late Hokkaido University scholar who himself acquired the majority of the 1004 Ainu skulls and skeletons that comprised that university's collection-the largest collection of Ainu remains in the world - was once apprehended by police following protests by local Ainu activists during one of his cemetery excavations. In a move that speaks to the immense influence that Japanese academics wielded, after being taken into custody Kodama demanded to speak to the local police chief who immediately freed him, chastised his arresting officers, and promised to notify the researcher of any deceased Ainu bodies he happened to come across in local prisons and hospitals. ${ }^{84}$ As is now evident, ethnological researchers often served as powerful agents of imperialism whose activities were deeply embedded within the colonial institutions that facilitated the oppression of colonized peoples, especially indigenous ones.

In the previous chapter, I examined the role of travel narratives, ethnographic depictions, cartographic projects, and biopolitical endeavors in the formation of Japanese and Ainu colonial identities, ending with a brief discussion of how nineteenth-century academic investigations into the racial origins of the Japanese were closely aligned with the growing tides of nationalism and imperialism. Through this dialogue the Ainu came

\footnotetext{
${ }^{84}$ Kodama Sakuzaemon, “Kinkyū o yōshita ainu kenkyū," [Ainu Studies Required Urgency] Hokkaido no bunka 21 (1971), 7.
} 
to serve as a dialectical counterpoint to modern Japanese in that the Ainu's status-like those of indigenous peoples elsewhere - was reduced to a static relic of humanity's past, an anachronist representation of pre-civilized human societies inundated by the wave of modern progress. This image of the Ainu was juxtaposed with what was referred to as a "restoration" of Japanese civilization and enlightenment, one that fused technology and ideas from the West with gripping, albeit largely invented, notions of Japanese tradition and spirit.

In this chapter, I continue this line of inquiry to show how Meiji-era discourse in the physical and social sciences further contributed to the refashioning of Ainu and Japanese identities in the context of deepening colonialism. The logic of race, nationalism, and empire reified popular perceptions of the Ainu as a 'vanishing' race. Researchers scoured Ainu lands in search of human remains and artifacts, as well as living subjects, upon which to construct their racialist theories. Informed by this research, policymakers carried out assimilation and eugenics programs to hasten Ainu ethnic negation. "Kill the Indian, save the man" was the motto that sought to justify programs of this sort in the United States, and Japanese policymakers applied a similar rationale to their relations with the Ainu, as well as to other colonized peoples within their empire. According to this theoretical framework, the Ainu people were 'dying race' destined to disappear and make room for an advancing Japanese nation, though in actuality their bodies, identities, culture, and history were being slowly subsumed into a new order of Japanese imperialism.

\section{The Emergence of Anthropometry and Scientific Racism in Western Thought}


To properly contextualize the study of Ainu skeletal remains and understand how they were used to racialize Ainu and Japanese bodies we first need to examine the development of anthropometry and its connections to scientific racism and Darwinian evolutionary theory, two ideas that entered Japan alongside anthropometrical methodology in the late nineteenth century. The modern scientific study of human remains dates back to the eighteenth century and was foundational to the pursuit of Western medical knowledge. These activities were also integral to the development of racial theories in Europe that sought to categorize the new peoples encountered through increased global commerce and the spread of colonialism. During this period, Western medical researchers often ran afoul of political and religious leaders and resorted to illicit means to acquire their biological specimens, including gravedigging, working with organized criminal entities, and bribing officials in prisons and hospitals. The spread of Western imperialism brought these activities out of their dubious origins in the shadowy underbelly of Western societies and enabled researchers to carry them out openly in foreign lands.

As previously mentioned, Koganei was not the first individual in Japan to dig up Ainu bodies for anthropometric study. A substantial number of Western researchers, adventurers, and black marketeers had in the preceding decades arrived in Japanese ports in Yokohama, Kobe, and Hakodate and employed similar methods to those of Koganeitaking physical measurements of live Ainu subjects and exhuming Ainu gravesites in search of rare artifacts and biological remains. In one infamous case in 1866, the British Consul in Hakodate, Captain Howard Vyse, was implicated in the robbery of Ainu graves 
and the smuggling of the pilfered remains to the British Museum in London. ${ }^{85}$ Local Ainu protested the plundering of their gravesites and appealed to the Tokugawa government who considered the acts a violation of Japanese territorial sovereignty. After a two-year diplomatic dispute Britain finally acceded to Japanese demands: Vyse resigned and the British Museum was ordered to return the confiscated remains of 17 individuals to the Ainu. Although a shipment of Ainu bones was returned to Hakodate, scholars now argue that at least some of the bones the museum sent were fakes, as recent DNA testing has identified the Ainu remains of at least 3 individuals among those in the museum's current collection likely having come from the Hakodate excavation. In a cruel twist of fate, even the remains that were returned by the British Museum were reexcavated decades later by Japanese researchers with the help of the police, even as local Ainu residents prostrated themselves on the graves in protest. ${ }^{86}$

The involvement of a foreign consular official in a plot to steal Ainu remains is much less strange than it may appear; the trade in cultural artifacts and human remains, especially rarities like those belonging to the Ainu, could be quite lucrative, and officials in diplomatic and colonial institutions were often recruited by researchers and museum curators to make such acquisitions for their collections in Europe and the United States. Samuel George Morton - a respected physician, anatomy professor, and president of the Academy of Natural Sciences of Philadelphia — was particularly adept in leveraging these

\footnotetext{
${ }^{85}$ John Denney, Respect and Consideration: Britain in Japan 1853-1868 and Beyond (Leicester: Radiance Press, 2011), 482-485; Hugh Cortazzi, Victorians in Japan: In and Around the Treaty Ports (London: Bloomsbury Academic, 2012), 44-45; Details on the incident can be found at the UK National Archives, Foreign Office, FO 46/88.

${ }^{86}$ ann-elise lewallen, "Bones of Contention: Negotiating Anthropological Ethics within Fields of Ainu Refusal," Critical Asian Studies 39:4 (2007), 516 and Koida Takeru, Ainu funbo tōkutsu jiken [Ainu Illegal Grave-Digging Scandals] (Sapporo: Miyama Shobō, 1987).
} 
types of social connections to amass his "American Golgotha," the first truly large and diverse collection of human skeletal remains ever assembled. According to Ann Fabian, Morton's 138 donors included "missionaries in Africa, doctors in Florida and Cuba, diplomats in Mexico and Cairo, white settlers sulking through hot summers in Indiana, soldiers in Georgia, explorers in the Arctic, scientists in Oregon, and a president of Venezuela. ${ }^{" 87}$ If the logic of Western imperialism and white supremacy served as the intellectual foundation for the racialist study of the deceased, then the nexus of global commerce and colonial institutions functioned as its arbiter allowing researchers to negotiate and employ strategies to gain unprecedented access to skeletal remains from various peoples throughout the globe.

While the origins of Western racialist thought remain a contentious topic, there is a general consensus among scholars that modern racist discourse developed in conjunction with the rise of European imperialism, the Enlightenment, and the Scientific Revolution. Prior to this, in Medieval and Renaissance-era Europe, ethnic prejudices and proto-racialist ideas of foreign others certainly existed having especially been shaped by European experiences during pivotal events such as the Crusades, the Iberian Reconquista, and the "discovery" of the Americas. Though some pre-Enlightenment thinkers began to question the identarian nature of European peoples, both in relation to one another and vis-à-vis the multitude peoples that populated the wider world beyond the European peninsula, ecclesiastical influences remained predominant. The position of the Church was clear: the unity of humankind had been affirmed in scripture. One need

\footnotetext{
${ }^{87}$ Ann Fabian, The Skull Collectors: Race, Science, and America's Unburied Dead (Chicago: The University of Chicago Press, 2010), 36.
} 
only look to the Spanish Inquisition, however, to see how even the church leadership succumbed to popular conceptions of ethnic difference, and how this could quickly turn tragic.

By the late eighteenth century, as the ties that bound colonial realities to the study of natural history became more intimately connected, Western racialist thought underwent a profound transformation. Francisco Bethencourt notes that "racial classification, formulated in the eighteenth and nineteenth centuries in Europe and the United States for scientific purposes, was intended to include all people of the world in a relational, systemic, and hierarchical arrangement," a taxonomic approach that "went well beyond simple variety in skin color." ${ }^{98}$ Many pre-modern notions of ethnic and racial difference no doubt exerted some influence upon the development of modern racial theories, notably the Greco-Roman belief in the impact of climate and geography upon human appearance, the Aristotelian notion of "natural slavery," and mythological associations of foreign 'others' with animals and other non-human entities. Yet, rather than being articulated as a mere abstract division of humankind based on various categories of perceived exotica, such as diet, skin color, and cultural practices, Western researchers instead came to view "race" as a tangible and concrete feature of human existence, with many believing it the primary determinant of human potentialities. To this effect, crania and other skeletal remains from both animals and humans were dug up, ordered, compared, and a hierarchy of human difference was erected that divided the worlds' peoples according to their assumed proximity to and distance from primates ${ }^{89}$ In

\footnotetext{
${ }^{88}$ Francisco Bethencourt, Racisms: From the Crusades to the Twentieth Century (Princeton: Princeton University Press, 2013), 2.

${ }^{89}$ Stephen Jay Gould, The Mismeasure of Man (New York: W.W. Norton, 1996), 11.
} 
other words, through the language and practices of science the various inchoate ideas of "race" that wormed their way into the Western imagination for centuries were catalogued, rationalized, and imbued with a scientific allure by researchers who reimagined the essentialization of racial difference, and with it pretenses to white racial supremacy, on the basis of new forms of empirical observation.

Craniometry was the most widely-employed and viewed as the most promising of the methodologies used to calculate "racial" difference; it was first conducted in such a manner in the 1750s by Dutch physician Petrus Camper (1722-1789). Camper was critical of polygenesis, continental determinism, and the role of skin color in distinguishing race, instead arguing that manners, customs, and diet shaped the very structure of human bodies. Camper concluded that skeletal structure was generally similar according to most measurements except for the 'facial angle,' a triangulated space from the line at the top of the nasal bone to the front of the head and to the ear. ${ }^{90}$ Camper compared the skulls of apes and humans to the heads of Greco-Roman statuesconsidered by many in elite European circles as the epitome of human beauty, and symbolic of unparalleled intellect—and argued that European facial angles were closer to this ideal than those of blacks and Asians, which he claimed were closer to primates. ${ }^{91}$ Johann Friedrich Blumenbach (1752-1840) and Georges Cuvier (1769-1832) expanded

\footnotetext{
${ }^{90}$ Bethencourt, Racisms, 258-261, and Miriam Claude Meijer, Race and Aesthetics in the Anthropology of Petrus Camper (1722 - 1789) (Amsterdam: Lodopi, 1999).

${ }^{91}$ Camper's sample size was far too low to make such a generalization - he claimed to have experimented on around 50 bodies - a point noted by later critics of his findings who themselves labored to collect much larger sample sizes of human remains from which to base their own conclusions. The contemporary consensus is that traits like the facial angle are not, in fact, different according to ethnicity but rather are highly individualized. See Petrus Campus, Demonstrationum anatomico-pathologicarum [1760] and Miriam Claude Meijer and Petrus Camper, "Petrus Camper on the Origin and Color of Blacks," History of Anthropology Newsletter 24:2 (1997).
} 
Camper's methods though they reached quite different conclusions. Blumenbach accumulated Europe's first large scientific collection of crania consisting of approximately 250 specimens, and he coined the term "Caucasian" to describe the ancient Central Asian ancestors of modern Europeans, which he believed to be the highest among races. ${ }^{92}$ Interestingly, Blumenbach's views were complicated by his belief in the capacity of other races for improvement, his fervent abolitionism, and his critique of prejudice against mixed-race and "savage" peoples. On the contrary, Cuvier-a leading scientific voice of his day and a critic of Lamarckian notions of species transformation ${ }^{93}$-argued that biological entities existed in static typology, thus the hereditary configurations that constituted racial difference made Caucasians the most civilized and beautiful of the world's peoples and other races innately and immutably inferior. ${ }^{94}$ Cuvier also originated the myth of the "apish pelvis" in African peoples, a false assertion rehashed by numerous historical actors over the centuries to argue for black “inferiority" and "proximity to apes." Arthur Gobineau (1816-1882) reiterated Cuvier's apish pelvis commentary but became critical of the extant methods of skull measurement. He agreed with Blumenbach's ideas on the Aryans to whom he attributed responsibility for quite literally "all" of the worlds civilizational achievements before their "pure blood" was diluted through miscegenation with other human groups. ${ }^{95}$ Northern European racial

\footnotetext{
${ }^{92}$ Blumenbach noted that many of those he saw his collection commented that a Georgian woman's skull was the most aesthetic and symmetrical. He used her skull as representative of the "Caucasian" race, which he named, and argued that contemporary Europeans were their most direct descendants.

${ }^{93}$ The idea of the inheritance of acquired characteristics passed from one generation of species to another is incorrectly attributed to the work of Jean-Baptiste Lamark, but these ideas had been argued since Hippocrates and Aristotle.

${ }_{94}$ Johann Friedrich Blumenbach, The Anthropological Treatises, trans. and ed. Thomas Bendishe (London: Anthropological Society, 1865); Bethencourt, Racisms, 263-265.

${ }^{95}$ See M. A. De Gobineau, Essai Sur L'inégalité des Races Humaines [An Essay on the Inequality of Human Races] (Paris: Librairie de Firmin Didot Fréres, 1853). He argued that only Caucasians were
} 
stock and civilization were, in his view, superior to those of other peoples because, he argued, they had retained the highest measure of ancient Aryan blood.

Gobineau's own work was rooted in the earlier ideas of Georges Louis Comte de Buffon, who in Histoire Naturelle, Générale et Particulière (1749) was the first to use "race" in the modern sense of the word, arguing that "mankind are not composed of species essentially different from each other," but rather "one species, who, after multiplying and spreading over the whole surface of the earth, have undergone various changes by the influence of climate, food, mode of living, epidemic diseases, and the mixture of dissimilar individuals." ${ }^{96}$ Buffon believed that the "white races" were closest to this original human prototype while other "primitive races" had experienced a history of degeneration. Gobineau, inspired by the literary Romanticism of his day, perhaps, and his fervent defense of the Ancien Régime in post-revolutionary France, affixed to Buffon's ideas the notion of an ancient and elite Aryan bloodline.

Interestingly, it is here that we can see the origination of Western racialist dialogue concerning the Japanese and the Ainu. The earliest reference to Japan here comes from Marco Polo's travel diaries in the early fourteenth century; he described the Japanese as "white, civilized, and well-favored" though he himself had never set foot in the country. ${ }^{97}$ The first Europeans to reach Japan were the Portuguese, or rather Jesuits under the auspices of the Portuguese crown, in the mid-sixteenth century. The Jesuits

capable of developing civilization whereas other races could at most only resort to mimicry of civilized culture.

${ }^{96}$ Georges Louis Comte de Buffon, A Natural History, General and Particular, vol. 1, trans. William Smellie (London: Richard Evans, Paternoster-Row, and John Bourne, 1817), 286, 280-281.

${ }^{97}$ Marco Polo, The Book of Ser Marco Polo the Venetian concerning the Kingdoms of the East, vol.2, ed. Henry Yule (London: John Murray, 1875), 237. 
described the complexions of both Japanese and Ainu they encountered as "white," though they noted that Japanese and Ainu communities differed according to European notions of civilization. The Ainu were depicted as excessively hairy "wild men" similar to the Germanic peoples of classical antiquity, while Japanese civilization was described as on par with, if not superior to, those of Europe ${ }^{98}$ This rosy view of the Japanese was no doubt influenced by the Jesuits successful proselytizing efforts. At the height of missionary activity in the 1580 s there were roughly 150,000 Japanese converts, the largest Christian community in Asia. ${ }^{99}$ The violent persecution of Christians and the expulsion of the Jesuits in the mid-seventeenth century changed European attitudes toward the Japanese, however.

From the mid-sixteenth century to 1853 the Dutch were the only Europeans allowed to establish official relations with the Japanese though they were confined to an isolated trading post in Dejima. Through this position they became the sole conduit for the exchange of knowledge between Japan and Europe during the Enlightenment. It was also during this period that Enlightenment figures conceptualized modern civil and human rights dialogue, which, they contended, made clear the primacy of European "civilization" over an "Oriental despotism" that slowed progress and inventiveness in Asian countries. Rotem Kowner points out that it was at this point that Europeans began to identify the Japanese as members of a new "yellow" race, occupying a space in the Western racial hierarchy between the "superior" whites and "savage" Africans and

\footnotetext{
${ }^{98}$ Josef Kreiner, “ The European Image of the Ainu as Reflected in Museum Collections," Ainu: Sprit of a Norther People, ed. William W. Fitzhugh and Chisato O. Dubreuil (Washington D.C., Smithsonian Institution, 1999), 125.

${ }^{99}$ Rotem Kowner, From White to Yellow: The Japanese in European Racial Thought, 1300-1735 (Montreal and Kingston: McGill-Queen's University Press, 2014), 71.
} 
Amerindians. ${ }^{100}$ Meanwhile, European curiosity of the Ainu grew and they were brought into greater focus under the Western gaze as objects of romantic primitivism, a prime example of le bon sauvage. ${ }^{101}$ The case of Philipp Franz von Siebold is particularly instructive here. Siebold is commonly known among Japanologists as a leading figure in introducing Western medical knowledge and surgical techniques to Japan in the 1820s. Siebold, like other medical practitioners at this time, was an avid study of natural history and biology, and a lesser known fact is that after meeting Tokunai Mogami and other members of Japan's Ezo expeditions - their importance to the colonization of Ainu lands was detailed in chapter one - he developed a strong curiosity about the Ainu. ${ }^{102} \mathrm{He}$ conducted his studies from afar - travel within Japan was highly restricted for foreigners and venturing to Ezo utterly unthinkable — and his multivolume work, Nippon, spread the idea of a possible shared racial connection between Europeans and the Ainu. ${ }^{103}$ Thus, in the European imagination the Ainu became a small group of "white" noble savages adrift in a vast "yellow" sea of Asian despotism.

It was also during this period that scientists in the United States came to play a prominent role in the study of natural history and ethnology. One reason for this development is that these fields addressed crucial questions about the role of race relations between whites, blacks, and Native Americans that lay at the heart of two of the most visible fault lines in American society: the institution of slavery and Westward

\footnotetext{
${ }^{100}$ Ibid., 278-282.

${ }^{101}$ Kreiner, "The European Image," 125.

${ }^{102}$ In 1829, Siebold's possession of maps and manuscripts from Mamiya Rinzō and Inō Tadataka's expeditions in the Japanese north led to his arrest. Japanese authorities subsequently charged him with espionage, and he was expelled from the country.

${ }^{103}$ Siebold did not use the word "Caucasian" explicitly, but he argued that the Ainu had a history on the Eurasian continent going back thousands of years. The implication would have been clear enough to informed readers.
} 
expansion. Conversely, by taking advantage of black enslavement and the colonization of Native lands researchers gained access to vast quantities of Native American and black remains. Samuel George Morton (mentioned above) was perhaps the most influential of these figures within the American scientific community. He pioneered the study of cranial cubic capacity for the calculation of brain size and applied this method to the study of racial difference. The sum of his research was published in two works: Crania Americana (1839) and Crania Agyptiaca (1844). In the former, he argued that the data gathered from his extensive collection of Native American and black skulls supported Gobineau's thesis that Indians and blacks were biologically inferior and incapable of feats of civilization; in the latter work, he took this idea even further claiming that the ancient Egyptians who built the pyramids were, in fact, Caucasians who had ruled over an inferior class of black servants. ${ }^{104}$

In Morton's work we can trace the influences of Blumenbach, Cuvier, and Gobineau not only in terms of methodology but also in their transposition of long-held European biases toward foreign others into the emerging language of scientific inquiry. Morton, himself, was not widely known outside of academic circles, but more popular and charismatic figures like the best-selling author and phrenologist George Combe, the famed Egyptologist George Robbins Gliddon, and the Harvard polymath Louis Agassiz found his work inspirational, and they and their protégés continued to spread his methods

\footnotetext{
${ }^{104}$ Samuel George Morton, Crania Americana; or, A Comparative View of the Skulls of Various Aboriginal Nations of North and South America (Philadelphia: J. Dobson, 1839), and Crania Agyptiaca; or, Observations on Egyptian Ethnography, Derived from Anatomy, History, and the Monuments (Philadelphia: J. Pennington, 1844). His conclusions were based on measurements of hundreds of white, Native American, and African skulls, including those of Egyptian mummies. He claimed that Caucasian brains were biggest at an average of 87 cubic inches; Indian brains had only 82 and blacks 78 . His findings were disputed as early as the end of the nineteenth century.
} 
and ideas across Europe, the United States, and later to Japan. Even critics of Morton and his ilk, like Franz Boas and Charles Darwin, continued to employ anthropometric methodology while locating their own works within the racialist scientific dialogue they inherited. The works of Darwin and Herbert Spencer ${ }^{105}$ added yet another layer to the global dialogue on "race" and "civilization" in the late nineteenth and early twentieth centuries, and to this we must now turn.

\section{Scientific Racism and Social Darwinism Enter Japan}

In 1877 Edward Sylvester Morse, a Harvard zoology lecturer and protégé of Louis Agassiz, arrived in Japan for what was meant to be a brief study of the country's brachiopods but left two years later after serving as a professor at the newly established Tokyo Imperial University. He is widely regarded as the person who introduced evolutionary theory to Japan, though the veracity of this statement is quite complicated if not altogether false. Firstly, long before the publication of Darwin's The Origin of the Species (1859) there existed a number of antecedents to naturalist and evolutionary thought in Tokugawa Japan, including the work of Kaibara Ekken (1630-1714), sometimes called the "Aristotle of Japan," and Yamagata Bantō (1748-1821) whose ideas located the origins of human life in ever-changing natural processes. ${ }^{106}$ Another scholar, Kamada Ryūō (1754-1821) drew on Neo-Confucian metaphysical analysis and

\footnotetext{
${ }^{105}$ Spencer had actually developed an independent theory of evolution before Darwin, but Darwin was the first to publish his work on the topic. Today, "Spencerian" thought is often referred to as "Social Darwinism," but Darwin was in fact the first to connect his ideas about the plant and animal kingdoms to human society (including on the subjects of race and civilization) making him the first Social "Darwinist." ${ }^{106}$ G. Clinton Godart, Darwin, Dharma, and the Divine: Evolutionary Theory and Religion in Modern Japan (Honolulu: University of Hawai'i, 2017), 18-19.
} 
came close to formulating a theory of evolution before the work of Darwin, himself, writing: "One species of plant changes and becomes the manifold of plants. One species of animal, insect, and fish changes and becomes the manifold of animals, insects, and fish." ${ }^{107}$ Secondly, scientific works detailing the Linnaean classification of flora and fauna and other important pre-Darwinian scientific ideas were included in European books that entered Japan through the Dutch trading port at Dejima. Especially following Shōgun Yoshimune's (1684-751) relaxing of restrictions on foreign books in 1720, rangaku (Dutch studies) and honzōgaku (natural studies) scholars throughout Japan became familiar with these trends in European biological thought. ${ }^{108}$ The first known written work discussing Darwinism is found in 北郷談 (1874) by the Shinto priest Aoiyama Nobuchiku (1836?-1909) who used Darwin's theories-insofar as he understood them — to attack both Buddhist doctrine and the growing influence of Christianity. ${ }^{109}$ Furthermore, Katō Hiroyuki and Toyama Masakazu—the two academics at Tokyo Imperial University who invited Morse to Japan — were already quite familiar with the ideas of both Darwin and Hebert Spencer. ${ }^{110}$ Nonetheless, Meiji-period scholars

\footnotetext{
${ }^{107}$ Kamada Ryūō, "Shingaku oku no kakehashi" [The Bridge to the Interior of Shingaku] [1822], in Nihon shisō taikei, vol. 42, Sekimon shingaku (Tokyo: Iwanami Shoten, 1970), 411. For more contextual analysis see Godart, Darwin, 19.

${ }^{108}$ See Timon Screech, The Lens Within the Heart: The Western Scientific Gaze and Popular Imagery in later Edo Japan (New York: Routledge, 2002).

${ }^{109}$ Eikoh Shimao, "Darwinism in Japan, 1877-1927," Annals of Science 38:1 (1981), 94; G. Clinton Godart, "Darwin in Japan: Evolutionary Theory and Japan's Modernity 1820-1970," (Phd diss., University of Chicago, 2009), 44-46; Godart, Darwin, 23. I used the original kanji here, as I was unable to find a consistent reading and/or translation of the title of this very rare manuscript. I found copies at three universities listed under two different kanji readings: Kitagōdan and Hokkyōdan. Shimao uses Hokkyōdan and translates the kanji as "A Talk Facing the Pole Star," though after seeing the manuscript I can say this is likely a misreading of the first two kanji as 北極 (North Star). Godart uses Kita ni mukau no hanashi (A Tale of Going to the North); it appears he first rendered the meaning of the kanji, though probably incorrectly, into English and then translated this back into modern Japanese.

${ }^{110}$ Sherrie Cross, "Prestige and Comfort: The Development of Social Darwinism in Early Meiji Japan, and the Role of Edward Sylvester Morse," Annals of Science 53:4 (1996), 335. Cross notes that Popular
} 
tended to view evolutionary theory as an entirely foreign idea, and it was through them that Morse was credited as having introduced Darwinian ideas to Japan through his research and lectures. ${ }^{111}$

Contrary to popular contemporary understandings of Western biological trends in the nineteenth century, Darwinism did not find universal acceptance among the scientific community of the time, and Social Darwinism - the application of natural selection and other Darwinian notions to human social issues of class, warfare, imperialism, and racefound fewer adherents in academia still. In fact, Louis Agassiz, Morse's mentor and a towering figure in American science, was a staunch creationist and Darwin opponent, and though many of Morse's classmates at Harvard had come to accept the merits of Darwin's theory, most still disavowed the Spencerian view that held human societies to be biological organisms whose dynamics were best explained through natural selection and the "survival of the fittest."112 Most within the Western academy were initially hesitant to apply these new biological theories to the study of human affairs, as they were still attempting to reconcile the endless string of biological mutations presented by Darwin with the view of immutable differences in both racial and special phenotypes that held sway over previous generations of scientists.

Finally, while Darwinism struck at the heart of biblical creationism the arguments of Social Darwinists went further still challenging even the humanistic values of the Christian faith. Morse had no such discrepancy here, however, writing that the

Science Monthly, the American journal and a popular vehicle for Spencerian ideas, was read by Meiji intellectuals prior to Morse's arrival. Morse had published several articles in the journal.

${ }^{111}$ Godart, Darwin, 20.

${ }^{112}$ Herbert Spencer, The Principles of Biology, vol. 1 (London: Williams and Norgate, 1864), 444. 
"inequality of man is based on natural laws" that governed the "moral and intellectual conduct of the world," 113 and that the "humane impulses of man often interfere with selective action." ${ }^{, 14}$ Gerard Clinton Godard notes that the most significant aspect of Morse's lectures in Japan was not his treatment of evolutionary theory, but his overall assertion that "accepting evolutionary theory meant rejecting Christianity," a position that attracted many young nationalists, progressive-minded scientists, and conservative elites who themselves harbored deep suspicions of Christianity and its missionaries whom they viewed as agents of Western imperialism. ${ }^{115}$ We must not underestimate the power of anti-Christian enmity during the early Meiji years. For one, it was strong enough to unite leading Buddhist figures with their Shinto counterparts who just years earlier led a nationwide campaign of destruction waged against Buddhist temples and iconography during their drive to enshrine Shinto as the new state religion. ${ }^{116}$ In Morse, Meiji Japan gained a mentor well-suited to its political and intellectual climate, who was at once severely antagonistic to the church and Spencerian to his core.

Morse was by training a zoologist, and he created a department of zoology and a museum of natural history at Tokyo Imperial University before his departure, but he gained notoriety for two other aspects of his tenure: his impassioned, widely-attended public lectures on Darwinism and Spencerism — these were attended by many in elite Tokyo society, including the Prime Minister and hundreds of members of the imperial family—and his discovery of the Ōmori shell mounds. Morse's lectures were warmly

\footnotetext{
${ }^{113}$ E.S. Morse Papers, Peabody and Essex Musuem, box 46, folder 1; box 55, folder 25, as cited in Cross, "Prestige," 332.

${ }^{114}$ Edward S. Morse, "Natural Selection and Crime," Popular Science Monthly 41 (August 1892), 442.

${ }^{115}$ Godard, Darwin, 30.

${ }^{116}$ Eikoh, "Darwinism," 94.
} 
received by Japanese academics and members of the elite who especially took to Spencerian views. ${ }^{117}$ Theirs was a world marked by a dizzying pace of innovation followed by rising social dislocation within which Japanese at all social levels endured pronounced anxiety over the intense pace of change and their nation's place in a new and strange world order. Many among the elite, including Morse's colleague, Katō Hiroyuki, had begun to turn against the popular movement for full democratization viewing more comprehensive democratic and civil reforms as an invitation to social chaos. ${ }^{118}$ For many in Meiji Japan, especially those among the elite and academia, the dog-eat-dog ethos of nineteenth-century capitalism and Western imperialist dominance in global affairs-what Katō described as "the strong eat the weak" (jyakuniku kyōshoku) ${ }^{119}$ —was widely interpreted as a natural manifestation of Social Darwinist and scientific racist ideas, which many regarded as one and the same. ${ }^{120}$ As Osamu Sakura has noted, within a decade of Morse's arrival and departure "21 works by Spencer were translated into Japanese...while only four books on biological evolution were translated." ${ }^{\prime 21}$ Thus, the theory of evolution was accepted more as a social theory than a biological one.

\footnotetext{
${ }^{117}$ Morse also invited guest lecturers from the West, such as Ernest Fenollosa, who also expounded on Social Darwinian theory for Japanese audiences. See Cross, "Prestige," 337-338.

${ }^{118}$ Eikoh Shimao, "Darwinism," 95; Watanabe Masao, The Japanese and Western Science, trans. Otto Theodor Benfey (Philadelphia: University of Pennsylvania Press, 1990), 73. Katō had been one of the most prominent leaders of Jiyu Minken Undō (Free Civil Rights Movement) before his sudden ideological reversal at the end of the 1870 s, after which he reasoned that democracy and human rights went against the Darwinian laws of nature. See Katō Hiroyuki, New Treatise on the Rights of Man [1881].

119 弱肉強食 (lit. “weak meat, strong eat”).

${ }^{120}$ Unoura Hiroshi, "Samurai Darwinism: Hiroyuki Katō and the Reception of Darwin's Theory in Modern Japan from the 1880s to the 1900s," History and Anthropology 11:2-3 (1999), 236-242.

${ }^{121}$ Osamu Sakura, "Similarities and Varieties: A Brief Sketch on the Reception of Darwinism and Sociobiology in Japan," Biology and Philosophy 13 (1998), 343. The author cites Yamashita Shigekazu, Supensā to Nihon kindai [Spencer and Modern Japan] (Tokyo: Ochanomizu shobō, 1983).
} 
Morse's discovery of the Ōmori shell mounds in 1877 was especially significant in that the human remains found there were the first established evidence of the Jōmon people - the prehistoric inhabitants of the Japanese archipelago. Morse's analysis led him to conclude that the Jōmon peoples were a race of cannibals who had settled throughout the Japanese islands and were possibly the ancient ancestors of the modern Japanese. ${ }^{122}$ The possibility of the ancestors of modern Japanese having been cannibals offended the sensibilities of young Japanese academics, many of whom were returning from their studies in Europe and the United States and endeavored to engage in their own study to correct what they saw as a cultural slander. ${ }^{123}$ Morse's discovery, therefore, intensified the search for Japanese racial origins, a question for which the racial origins of the Ainu became inextricably connected. Morse, himself, continued his research on Japanese racial origins the following year by venturing to Hokkaido and conducting fieldwork on the Ainu. Many Western and Japanese academics followed, for in the nineteenth-century scholarly imagination the answers to the mystery of human racial origins lay in wait, hidden deep inside the bodies of the living, and buried deep within the bones of the deceased.

\section{"Discovering" Ancient Aryans}

The racialization of Ainu bodies and the appropriation of Ainu remains grew steadily alongside the rise of anthropological research as both Western and Japanese

\footnotetext{
${ }^{122}$ Edward Morse, "Traces of Early Man in Japan," Nature 17 (1877) and "A Pre-Aino Race in Japan," Science 10 (1892).

${ }^{123}$ This was the position of Tsuboi Shōgōro. See Yamashita Shinji, "Somewhere in Between: Towards an Interactive Anthropology in a World Anthropologies Project," in Dismantling the East-West Dichotomy, ed. Joy Hendry and Heung Wah Wong (New York: Routledge, 2006), 177-182.
} 
academics descended upon Hokkaido in the late 1870s. They arrived to find Ainu communities that were being systematically looted, impoverished, and ravaged by disease. After the official annexation of the territory in 1869 the nascent Meiji government enacted a series of social, economic, and legal reforms that disenfranchised the Ainu and had the effect of increasing research access to their cultural and biological materials. The Land Regulation Ordinances of 1872 (Jisho kisoku) declared Ainu lands terra nullius allowing for their appropriation by militia-farmers (tondenhei) from the mainland. ${ }^{124}$ Meanwhile, Ainu communities in Hokkaido, the Kuriles, and Sakhalin were forcibly removed and relocated to agricultural reservations (hogochi), often comprised of the poorest quality soil. For hunter-gatherer peoples with scant knowledge nor experience of farming this was akin to a death sentence. The largest single relocation occurred after the 1875 Treaty of St. Petersburg when 841 Ainu from Sakhalin were relocated to Hokkaido where nearly half their number died within five years. ${ }^{125}$ The practice of Ainu removal occurred alongside laws that made hunting and fishing more difficult and banned Ainu customs and cultural practices, such as burning the homes of the deceased, and donning beards, tattoos, and earrings. Overfishing by Japanese commercial fisheries and other environmental damage severely depleted fish and deer populations that made up the bulk of the Ainu diet, as a greater influx of settlers increased incidences of epidemics.

\footnotetext{
${ }^{124}$ David L. Howell, Geographies of Identity in Nineteenth-Century Japan (Berkeley: University of California Press, 2005), 184-185.

${ }^{125}$ Richard Siddle, Race, Resistance and the Ainu of Japan (New York: Routledge, 1996) 62-68. Richard Siddle, "From Assimilation to Indigenous Rights: Ainu Resistance Since 1869," in Ainu: Sprit, 108. Per the treaty, the Ainu were made into Japanese nationals while their land was officially recognized as Russian territory. Other large relocations, such as those of Kurile Ainu, resulted in similar mortality rates.
} 
Despite these harsh conditions, Ainu communities continued to resist the plunder of their ancestral gravesites. In some cases, such as the 1866 Vyse Incident discussed earlier, the Tokugawa government had risked diplomatic incidents with Western powers while siding with Ainu protestors. The ethos of the Meiji period was quite different,

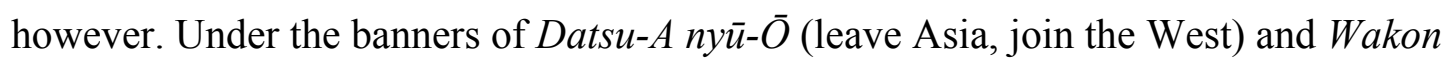
yōsai (Japanese spirit, Western learning), Western academic disciplines were utilized in the anthropological search for Japanese racial origins. Officials in the nascent Meiji state saw this research as integral to Japanese national identity; thus, researchers came to represent elite interests, the result being that instruments of state power were used to stifle Ainu resistance. Nonetheless, Ainu researchers were entirely cognizant that intruding upon Ainu gravesites could be dangerous business. Edward Morse, for example, wrote that during a Hokkaido research trip he encountered "a number of hairy Ainus, in a row, shouting at me and gesticulating...it suddenly occurred to me that they thought I was hunting for their graves, which they defend even to the extent of murder, and recalling the deadly poison of the arrow tips I reluctantly got up and walked away." ${ }^{126}$ Certainly, many Japanese found the idea of disturbing burial plots objectionable, but Ainu funerary practices contrasted markedly from those of the Japanese. Ainu graves were not separated by family unit, visits were conducted infrequently, and natural growth around gravesites was left undisturbed out of respect for the deceased. ${ }^{127}$ This created the perception among Japanese settlers that many Ainu

\footnotetext{
${ }^{126}$ Edward S. Morse, Japan Day By Day, 1877, 1878-79, 1882-83, vol. 2 (Boston: Houghton Mifflin, 1917), 12.

${ }^{127}$ Naohiro Nakamura, "Redressing Injustice of the Past: The Repatriation of Ainu Human Remains," Japan Forum (2018), 9.
} 
gravesites had been 'abandoned,' although Ainu researchers were evidently aware that this was not the case. Japanese laws protecting the integrity of gravesites continued to be defined by Japanese funerary practices, and it was not until the latter part of the twentieth century that the Ainu could count on legal protections to safeguard their ancestral burial grounds. ${ }^{128}$

As with Morse, most nineteenth-century research into human origins was conducted by laymen and/or scholars of other disciplines, such as medicine, philology, and, in Morse's case, zoology. Anthropology had yet to gain widespread recognition as an independent field of academic study, and so most researchers were simply carrying on a centuries-old tradition of amateur ethnological study. One of the earliest anthropometric surveys of the Ainu was conducted by the Kaitakushi advisor and American geologist Benjamin Lyman who during an 1874 geological survey of Hokkaidō took detailed measurements of the Ainu laborers under his employ. ${ }^{129}$ Lyman's study followed that of Bernhard Davis in 1870, who claimed that the four Ainu skeletons he examined bore a strong resemblance to those of Europeans; he also estimated that Ainu brain size was greater than any other group in Asia and closer in size to Caucasian brains. ${ }^{130}$ Heinrich von Siebold, an Austro-Hungarian diplomat and son of Philipp Franz von Siebold, endeavored to continue his father's research on possible Ainu-Caucasian racial linkages. He also conducted research on the remains found at the Ōmori shell mounds and determined that they belonged to a prehistoric Ainu community, ultimately concluding

\footnotetext{
${ }^{128}$ Ibid., 5-6.

${ }^{129}$ Siddle, Race, 78; Bain Attwood, The Making of the Aborigines (Sydney: Allen and Unwin, 1989), 1.

${ }^{130}$ Bernhard J. Davis, "Description of a Skeleton of an Ainu Woman and of Three Skulls of Men of the Same Race," Memoirs of the Anthropological Society of London 3 (1870), 21-40.
} 
that the Ainu had been the original inhabitants of Japan having in the past settled the entire archipelago. ${ }^{131}$ Albert L. Bickmore, naturalist and founder of the American Museum of Natural History, argued that the Ainu "call to mind the bearded peasants in Russia...they must be regarded as a branch of our Aryan family." ${ }^{, 132}$ German ethnographer and museum collector Wilhelm Joest wrote that the Ainu were of "such a low mental order that their faculties are hardly as developed as those of a Japanese child, a people full of dirt and vermin, who at festivals drink blood and eat raw meat" and lamented that they were "most like Europeans." ${ }^{, 133}$ These were among the early attempts to link the Ainu to Caucasians through anthropology and anthropometry.

The two Western figures who contributed most to the popularization of the Ainuas-ancient-Aryans hypothesis were the German physician Erwin Bälz (1849-1913) and the Anglican missionary John Batchelor (1855-1944). The outsized influence of both figures can be attributed to their long stays in Japan—roughly thirty years for Bälz and sixty-four for Batchelor-and the deep political and academic connections they made within and outside of Japan. Bälz entered the medical faculty at Tokyo Imperial University in 1876 and rose to become the personal physician for Emperor Meiji, as well as Prime Ministers Itō Hirobumi and Yamagata Aritomo. Bälz major contributions to the racialist dialogue of nineteenth-century Japan were twofold: (1) He argued that the modern Japanese population was a mix of Caucasians who arrived first to the archipelago

\footnotetext{
${ }^{131}$ Josef Kreiner, "The European," 126; Heinrich von Siebold, "Ethnologische Studien über die Ainos auf Yesso," Zeitschrift für Ethnologie 13 (1881), 1-38. He disagreed with Morse who believed the Ōmori remains to be those of ancient Japan and unrelated to the Ainu.

${ }^{132}$ Albert L. Bickmore, “The Ainos, or Hairy Men of Yesso," American Journal of Sciences 45 (1868), 360 .

${ }^{133}$ Wilhelm Joest, "Die Ainos," Zeitschrift für Ethnologie 14 (1882), 181. As cited in Kirsten Refsing, "Lost Aryans?: John Batchelor and the Colonization of the Ainu Language," Interventions 2:1 (2000), 2223.
} 
and a later wave of Mongolian peoples from Korea; (2) He argued on the basis of physical study that Ainu and Ryūkyūan peoples were racially similar and thus descended from the ancient first wave peoples. ${ }^{134}$ Later, Bälz added a third Malayan-Mongol type to the racial division of Japan. The "true Mongolian fine type" was represented by the upper classes of Japan, especially those in Kyūshū and Kansai, and was marked by a dolichocephalic skull, long face, high forehead, large eyes, aquiline nose, and a long, slender torso. The "Malayan-Mongol coarse type" was found among the lower classes and peoples in eastern and northern Japan, and was identified as having a brachycephalic round skull, broad nose, and thick body with strong, short legs. The third type, the Caucasian "Aino [sic] type," had the longest heads, roundest eyes, widest jawbones, and most prominent hair growth of the three types. ${ }^{135}$ Bälz argued this group had made the smallest contribution to the racial demography of Japan and could primarily be found in Hokkaido and Japan's northern territories.

As an English missionary based in Hokkaido, John Batchelor had a very different experience from Erwin Bälz. Batchelor was a strong advocate for Ainu social and political causes, especially in the areas of Ainu education, welfare programs, and the temperance movement, though these positions caused him to fall afoul of Japanese colonial authorities on a number of occasions. Batchelor's advocacy and deep connections to both Ainu and Japanese elites gave him a high social standing, and other

\footnotetext{
${ }^{134}$ Erwin Bälz, "åber die Rassenelemente in Ostasien, Speciell in Japan," Mittheilungen der Deutsche Gesellschaft für Natur- und Völkerkunde Ostasiens 8 (1900), 227-235. As cited in S.A. Arutiunov, "Ainu Origin Theories," in Ainu: Spirit, 29.

${ }^{135}$ Erwin Bälz, Die Ostasiaten (Stuttgart, 1901), 171. Cited in Rotem Kowner, "Lighter than Yellow, but not Enough': Western Discourse on the Japanese 'Race," The Historical Journal 43:1 (2000), 121-123. Also see Erwin Bälz (written Baelz), Awakening Japan: The Diary of a German Doctor (Indiana University Press, 1974).
} 
scholars and museum collectors often relied on his influence to complete their own work. Although very much an amateur, Batchelor was recognized as a leading authority on Ainu culture, folkways, and especially language. He devised a transcription method for rendering Ainu words and syllables into English through which he composed the first Ainu-language dictionary and translated biblical writings into Ainu, in addition to recording Ainu lore in English. Through various influential, though highly-problematic, philological works on Ainu grammar he determined that there was "an Aryan origin of the Ainu language,"136 however, later linguists have noted how Batchelor twisted Ainu grammar, going so far as to invent non-existent categories, such as gendered nouns, in order to make Ainu fit within the grammar and morphology of other languages within the Indo-European language family. ${ }^{137}$ Chiri Mashio, the first academic and professional linguist of Ainu ethnicity, remarked that despite the enduring popularity of Batchelor's Ainu dictionary, "I have never in my life seen a dictionary with so many flaws... it would be closer to the truth to say that it consists solely of flaws." ${ }^{138}$ Basil Hall Chamberlain, a contemporary of Batchelor and professor of linguistics at Tokyo Imperial University, was also a critic of his analysis, arguing that Ainu was an isolated language with no connection to the Indo-European language family. ${ }^{139}$ Still, Batchelor did more than perhaps any other person to spread the idea of the Ainu as a group of "lost Aryans" existing on Japan's northern frontier, an idea that remained predominant among Western

\footnotetext{
${ }^{136}$ John Batchelor, An Ainu-English-Japanese Dictionary, Including a Grammar of the Ainu Language (Tokyo: Methodist Publishing House, 1905) 76; John Batchelor, A Grammar of the Ainu Language (Yokohama: Kelly \& Walsh, 1903).

137 Refsing, "Lost Aryans," 25-29.

${ }^{138}$ Chiri Mashio, Ainugo nyūmon [An Ainu Primer] (Sapporo: Nire shobō, 1956), 237.

${ }^{139}$ Tamura Suzuko, “Ainu Language: Features and Relationships," in Ainu: Spirit, 62.
} 
and Japanese academics well into the twentieth century. It should be noted briefly that the Ainu Caucasian hypothesis never gained traction in Russia and Eastern Europe where the views of Lev Shternberg gained wide acceptance. Like Batchelor, Shternberg used linguistic analysis in addition to biometrical data to propose an Austronesian racial connection between the Ainu, Okinawans, and peoples of the South Seas. ${ }^{140}$

Here we should again turn our attention to the political context of Ainu and Japanese racialization. During the early decades of the Meiji period European, and especially American scholars, politicians, travel writers, and media personalities went to great lengths to influence public perceptions of Japanese racial characteristics, in effect distancing the Japanese from the "yellow" Chinese. Many o-yatoi gaikokujin (hired foreigners) who worked as university faculty and advisors to the Meiji government developed strong personal ties to Japanese friends, students, and colleagues, and many had a professional stake in portraying their Japanese hosts in a positive light. Bälz, is an instructive example; he worked closely with the most elite circles in Japanese society and married a Japanese wife with whom he fathered several children, giving him a deeply personal motivation to use his racial theories to elevate the Japanese in Western eyes. He was far from alone, however, and these efforts to raise the Western view of the Japanese race occurred at the expense of the Ainu who were viewed, curiously, as racially Caucasian and, therefore, "superior," but woefully behind the Japanese in terms of their civilizational development.

The American reception of Japanese diplomatic missions in the 1860s and 1870s demonstrates how geopolitical and economic considerations factored into Western racial

${ }^{140}$ Ibid., 63. 
depictions of the Japanese during this period. Popular media emphasized the strategic importance of political and economic ties with Japan with Harper's Weekly going so far as to call the Japanese "the British of Asia." ${ }^{141}$ These media representations also contrasted the racial, cultural, and gender identities of the Japanese with those of Chinese and other "Oriental" races. During this period, "Oriental" civilizations were highly sexualized in the Western imagination. This was represented most clearly, perhaps, in the Western image of the harem: exoticized spaces of unrestrained male perversion and deviancy filled by obsequious, servile women. Ikuko Asaka's study of Japan's first diplomatic mission to the United States in 1860 illustrates how newspapers covering the mission's visits to various American cities made sure to instill in readers a sense of familiarity with their Japanese visitors based on associations with normative Western marital practices. The New York Herald, whose owner, James Gordon Bennett, was vying for the position of ambassador to Japan, remarked that Japanese women were "recognized as companions...not merely treated as slaves...which goes far to show the superiority of the people to all other Oriental nations." ${ }^{142}$ Another newspaper added that Japanese wives were "as the equal and companion of a man," not regarded as "mere chattel, or as an instrument of pleasure." ${ }^{\text {143 }}$ Newspapers also described the phenotypal features of the Japanese embassy members as bearing resemblance to those of Caucasians, with thin noses, large foreheads, and light skin. ${ }^{144}$

\footnotetext{
141 “Our Japanese Visitors," Harper's Weekly, May 26, 1860, 322.

142 “Our Washington Correspondence,” New York Herald, May 24, 1860.

143 "Women of Japan," Frank Leslie's Illustrated Newspaper, May 26, 1860.

${ }^{144}$ Ikuko Asaka, "Colored Men of the East': African Americans and the Instability of Race in US-Japan Relations," American Quarterly 66:4 (2014), 981-982.
} 
Of course, not all people accepted this seemingly Caucasian racialization of the Japanese. As the mission traveled from city to city mobs of white working-class men assailed them with racist heckling, and during one procession a Japanese delegate was physically assaulted and almost dragged from his carriage. ${ }^{145}$ Nor were these negative racialist views of the Japanese confined to American white male rage. Remarking upon her travels in Hokkaido, the intrepid Victorian travel author Isabella Bird contrasted the Japanese she saw with the familiar "European" features of the Ainu, noting with particular distaste "the yellow skins, the stiff horse hair, the feeble eyelids, the elongated eyes, the sloping eyebrows, the flat noses, the sunken chests, the Mongolian features, the puny physique, the shaky walk of the men, the restricted totter of the women, and the general impression of degeneracy conveyed by the appearance of the Japanese." ${ }^{146}$ After Japan's success in the Russo-Japanese War (1904-1905) this chorus of racist antiJapanese voices was amplified. German Kaiser Wilhelm II hyperbolically decried Japanese success to other Western leaders: "This is the yellow peril, the greatest danger threatening the white race, Christianity, and our entire culture." ${ }^{147}$ Anti-Japanese discrimination reached a fever pitch in the United States, especially in areas along the west coast with large Japanese immigrant populations. Labor unions stepped-up their protests against Japanese immigration, and the following year the city of San Francisco passed a law enforcing the strict segregation of Japanese students. ${ }^{148}$ Across the Atlantic,

\footnotetext{
${ }^{145}$ Ibid.

${ }^{146}$ Isabella Lucy Bird, Unbeaten Tracks in Japan: An Account of Travels on Horseback in the Interior, vol. 2 (New York: G. P. Putnam's Sons, 1881), 75-76.

${ }^{147}$ Fürst Bernhard von Bülow, Memoirs of Prince von Bülow, vol. 2, trans. Geoffrey Dunlop and F. A. Voight (Boston: Little, Brown and Company, 1932), 72.

${ }^{148}$ For a comprehensive treatment of the global impact of the Russo-Japanese War see The Russo-Japanese War in Global Perspective: World War Zero, vol. 1, ed. John W. Steinberg, Bruce W. Menning, David Schimmelpenninck Van Der Oye, David Wolff, and Shinji Yokote (Boston: Brill, 2005) and The Russo-
} 
British journalist Thomas Crosland's The Truth about Japan (1904) exhorted Westerners to reconsider their attitudes to "the dearly-beloved Little Jap" whom he caricatured as a "stunted, lymphatic, yellow-faced heathen, with a mouthful of teeth three sizes too big for him, bulging slits where his eyes ought to be, blacking-brush hair, a foolish giggle, a cruel heart, and the conceit of the devil." ${ }^{\prime 49}$ In spite of Japanese military and political leaders' attempts to alleviate Western fears and dispel their racist assumptions through their surprisingly well-organized and humane treatment of Russian prisoners of war, ${ }^{150}$ these negative and racist perceptions of the Japanese continued to grow.

Within the deeply racialized white-nonwhite binary that undelay world affairs at the turn of the twentieth century, the defeat of a major "white" imperial power, Russia, by an upstart "yellow" nation, Japan, became an anti-imperialist rallying cry for nonwhite and colonized peoples throughout the world. The eminent African-American academic and civil rights activist, W.E.B. Du Bois, celebrated Japan's victory arguing that "the magic of the word 'white' is already broken" and that "the awakening of the yellow races is certain...the awakening of the brown and black races will follow in time." ${ }^{, 151}$ On the other side of the global racial divide, Russia's defeat filled many influential figures in the West with a strange blend of curiosity and dread. Scholars throughout the world had been trained to see race as a determining factor in the success of nations, and the change in the

Japanese War in Global Perspective: World War Zero, vol. 2, ed. David Wolff, Steven G. Marks, Bruce W. Menning, David Schimmelpenninck Van Der Oye, John W. Steinberg, Yokote Shinji (Boston: Brill, 2007).

${ }^{149}$ Thomas William Hodgson Crosland, The Truth about Japan (London: G. Richards, 1904), 1.

${ }^{150}$ Naoko Shimazu, Japanese Society at War: Death, Memory and the Russo-Japanese War (Cambridge: Cambridge University Press, 2009). International observers noted that Russian POWs had regular access to treatment by International Red Cross nurses, sufficient food, and luxury items; they were also permitted to visit local hot springs and ride bicycles in the countryside.

${ }^{151}$ W. E. B. Du Bois, “The Color Line Belts the World,” Collier's 28 (October 20, 1906), 20. 
global order ushered in by Japan's victories only made the study of Japanese and Ainu racial identities evermore prominent. Within the elite Meiji milieu of politicians, industrialists, military officers, and academics this issue had long been paramount in importance to emergent questions of national identity and empire.

\section{The Ainu Enigma and the Construction of the Yamato Race}

We have reviewed the Western racialist dialogue concerning the Japanese and the Ainu, and the relationships therein, and now to continue further we must come full circle, back to Koganei Yoshikiyo, Tsuboi Shōgōro, and others who made up the first generation of Japanese researchers in the modern biological and social sciences. In some ways, this generation of scholars was continuing the work of Edo-period scholars, like Arai Hakuseki (1657-1725), Tō Teikan (1732-1797), and Motoori Norinaga (1730-1801), who had conducted their own investigations on the origins of the Japanese people. Arai and Tō both incorporated archaeological and historical data and theorized common ancestral links between the Japanese and Korean peoples. Mootori, an early figure in the nativist kokugaku (national learning) movement used premodern philological studies of the Kiki myths to criticize Asian continental influence on Japanese culture and societyhis was essentially a seditious political movement that challenged the Neo-Confucian mores of the Tokugawa court—which he felt had corrupted the ancient spiritual and political values of a romanticized and essentialized Japanese people. A growing scholarly consensus has emerged in recent years demonstrating the many links between this premodern nativism and Meiji-era nationalism. ${ }^{152}$ One of the most interesting is what

\footnotetext{
${ }^{152}$ See the work of David Howell, Susan Burns, Herman Ooms, Harry Harootunian, Gavin McCormack, Daniel Botsman, and Jeffrey Paul Bayliss, among others.
} 
appears to be the racialization, or at least the ethnic othering, of Japan's premodern outcaste communities, especially the Eta, or Burakumin in modern parlance. ${ }^{153}$ Kokugaku scholars looked for evidence in historical and religious texts that placed the origins of the Burakumin among both ancient Indian Dalit communities and Korean immigrants from the Imjin War (1592-1598). ${ }^{154}$ These ideas were rehashed many times in the nineteenth and twentieth centuries, often in discussions of anti-Korean racism and the Japanese colonization of the Korean peninsula between 1910-1945, along with numerous other theories regarding Japanese and Ainu origins. Stefan Tanaka argues that in the social, political, and cultural tumult that accompanied the transition from the Edo to Meiji periods "old things became a symbol of stability that ground[ed] a changing society.",155 This quest for "old things" underlay an entire array of nationalistic myths, such as the dubious 2,600 year-old origins of Japan's “unbroken” imperial line, just as it fueled academic inquiry into Japan's racial past. In short, studies of Japan's ancient culture, its civilization development, and its racial origins were at the heart of the Meiji government's construction of a modern national identity.

The first studies of Ainu bodies conducted by Koganei and Tsuboi were intimately connected to this nationalist project. Recall that the Ainu were already objects

\footnotetext{
${ }^{153}$ In the Edo period there existed two primary groups of outcastes, both called by highly disparaging names: Eta (lit. much filth; later called burakumin) — this included tanners, butchers, and professional executioners, all occupations believed to be spiritually unclean - and hinin (non-people) - street performers, beggars, and other undesirables. Both groups were "liberated" in the early years of the Meiji period and given the status of "new commoners" (shinheimin), though systemic discrimination against families of buraku descent continued well into the twentieth century.

${ }^{154}$ See Jeffrey Paul Bayliss, On the Margins of Empire: Buraku and Korean Identity in Prewar and Wartime Japan (Cambridge: Harvard University Asia Center, 2013). The links between Buraku and Ainu activism in the twentieth century will be explored in the following chapter.

${ }^{155}$ Stefan Tanaka, Japan's Orient: Rendering Pasts into History (Berkeley: University of California Press, 1995), 36.
} 
of significant interest among Western academics, and the theories of Heinrich von Siebold and Erwin Bälz had already connected the Ainu to the Jōmon remains discovered at the Ōmori shell mounds. Recall, also, that Edward Morse had proposed that the Ōmori remains were those of ancient Japanese cannibals unrelated racially to the Ainu. His conclusion was based on the fact that the Jommon had created pottery-among the earliest in the world, in fact—and the Ainu did not. Both theoretical strains had enormous implications for the study of Japanese race and civilization, thus the primary objective for both Koganei and Tsuboi was to determine which version, if any, was correct. Koganei, a student of Erwin Bälz, after comparing Ainu skeletons with those of ancient Jōmon settlements, found that he agreed with his mentor that the Ōmori remains, indeed, belonged to the Ainu who were the indigenous people of Japan, a point he made emphatically, declaring that "the Japanese empire once was the empire of the Ainu.".156 He disagreed, however, with the popular Western notion that the Ainu were Caucasian arguing instead that they are a Rasseninsel (isolated race). Tsuboi, who conducted his own concurrent studies on Ainu bodies and the skeletal remains at Ōmori put forth his Koropokkuru thesis, ${ }^{157}$ the idea that the Jōmon were related not to the Ainu but to an ancient ancestral race of the Japanese family that inhabited the archipelago prior to the arrival of later waves of immigrants from continental Asia. Their debate continued to play out in the pages of the Tōkyō jinruigakkai zasshi (Tokyo Anthropology Society

\footnotetext{
${ }^{156}$ Koganei Yoshikiyo, “Aino jinshu ni tsuite," [On the Ainu Race] Tōkyō jinruigakkai zasshi 94 (1894), $128-135$.

${ }^{157}$ Tsuboi Shōgōro, "Koropokkuru Hokkaidō ni sumishi narubeshi," [The Koropokkuru Must Have Inhabited Hokkaido] Tōkyō jinruigakkai hōkoku 2:12 (1887), 93-97. Tsuboi clearly was inspired by Ainu mythological tales, as the Ainu had legends of a race of small, forest-dwelling people (Ainu: Kor-pok-kur) whose own existence in Ainu-inhabited lands preceded their own.
} 
Journal) until Tsuboi's death in 1913 after which Koganei's theories on Ainu origins became predominant.

The existence of Tsuboi's Koropokkuru peoples is no doubt unfounded, but his theory had a lasting impact in that it challenged extant Western theories in two profound ways: first, it centered questions of indigeneity in the Japanese islands on the ancient ancestors of the Japanese themselves, while decentering the Ainu; second, it complicated the racial narratives of the Japanese people, in effect, solidifying the argument that the Japanese were in fact a mixed-race people. Richard Siddle argues that this initial debate helped popularize the question of Ainu and Japanese racial origins among the educated public who were "keen to absorb scientific knowledge and understanding" and "were familiar with [its] main propositions." ${ }^{, 158}$ Writings on the topic proliferated quickly in nascent academic journals spanning a range of subjects, including history, archaeology, geology, and medicine, with over two hundred articles having been published in the Tōkyō jinrui gakkai zasshi on Ainu-related topics in the last twenty-five years of the Meiji period alone.

The theories of Tsuboi and Koganei dovetailed with another pressing debate about the Japanese race occurring at the same time. Throughout the late 1870s to the late 1890s, when the Meiji government was considering the idea of "mixed residence" with foreigners, ${ }^{159}$ the Japanese historian and economist, Taguchi Ukichi (1855-1905) —"the

\footnotetext{
158 Siddle, Race, 82.

${ }^{159}$ Until the passage Imperial Ordinance No. 352 (1899) foreigner settlement in Japan was relegated to special extraterritorial zones. Changing this arrangement was highly debated, not simply as a matter of xenophobic fear, but also due to the diplomatic and legal complications that could accompany reform.
} 
Japanese Adam Smith," ${ }^{, 160}$ as some scholars have referred to him—urged officials to go further, to institute policies of mass immigration with the United States as a model. Taguchi argued that "people are united... when and only when they share common interests, and never because the belong to the same race. ${ }^{\prime 161}$ He continued by noting that although some argued that the Japanese were racially homogenous, in the past Japan had immigrants and foreign residents from Korea, China, and even Europe living within its borders. Taguchi's confidence seems to have been supported by his belief that the Japanese were members of the Caucasian race, and therefore in no way racially inferior to the Western peoples who resided in the extraterritoriality territories. Japan's victory in the Sino-Japanese War (1894-1895) reinforced his opinions that the Japanese could not be placed into the same category as the "inferior," "yellow" Chinese; instead, he argued, Japanese were descended from the Hungarians and Turks. ${ }^{162}$ Taguchi later contended that, according to his linguistic analysis, the Japanese race was, in fact, "the true descendent of the Aryan race" and European peoples who claimed Aryan heritage had

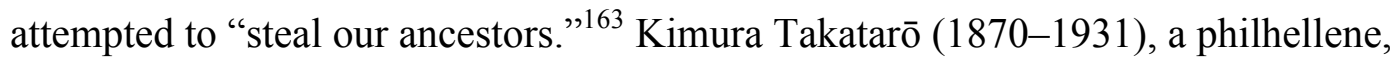
translator of Greek philosophical works, and contributor to the far-right nationalist magazine, Nihon shugi (Japanism), also argued that the Japanese were of Caucasian extraction, but based on similarities between Japanese Kiki myths and those of the Hebrews and the Greeks. He also criticized professional academics, such as Tsuboi, who

\footnotetext{
${ }^{160}$ Sources of Japanese Tradition, vol. 21600 - 2000, ed. William Theodore De Bary, Carol Gluck, and Arthur E. Tiedemann (New York: Columbia University Press, 2005), 1227.

${ }^{161}$ Taguchi Ukichi, "Naichi zakkyoron" [1879], As cited in Oguma Eiji, A Genealogy of Japanese SelfImages, trans. David Askew (Melbourne: Trans Pacific Press, 2002), 19.

162 Taguchi, "Nippon jinshuron" [1895], as cited in Ibid., 145.

${ }^{163}$ Taguchi, "Kokugo jō yori kansatsu shitaru jinshu no shodai," Shigaku zasshi 12:6 (1901), 18, 26.
} 
argued that the Japanese were of mixed racial origin — Tsuboi's "mixed race nation" position was, in fact, the predominant one among Japanese academics and government officials from the Meiji to the postwar period —stating that "the imperial universities are a cesspool of imbecile scholars...theorists who argue that the Japanese race is of inferior origin." ${ }^{\prime 64}$ This was a clear contrast from the eugenics arguments of Takahashi Yoshio who exhorted Japanese to intermarry and mix their blood with Western Caucasians in order to improve their own racial status, physiology, and intellect. ${ }^{165}$

By tracing these early ideas on Japanese racialization, we can see the development of what Oguma Eiji describes as the schism between "mixed-race nation" and "national polity" (kokutai) theories in Japanese academic and political dialogues. "National polity theory" refers to the ruling ideology of the Meiji state, related to "State Shintoism" and/or "Shinto nationalism," which saw the population of Japan as a large family of imperial subjects linked by ancient bloodline to the emperor who presided as the father of the nation. ${ }^{166}$ The idea itself was deeply rooted in Confucian tradition though, in practice, Meiji oligarchs combined it with modern statecraft chiefly inspired by German unification under the ascendant Prussian state. Central to both German unification and Meiji political reform was the notion of "volk," translated as "minzoku" in Japanese, a term that described the popular, romanticized nineteenth-century ethno-

\footnotetext{
${ }^{164}$ Kimura Takatarō, Sekaiteki kenkyū ni motozukeru Nippon taikoshi (Tokyo: Hakubunkan, 1911), xiv. National Diet Library Digital Collections: http://dl.ndl.go.jp/info:ndljp/pid/772307.

${ }^{165}$ Takahashi Yoshio, Nippon jinshu kairyōron (Tokyo: Ishikawa Hanjirō,1884). National Diet Library Digital Collections: http://dl.ndl.go.jp/info:ndljp/pid/832935.

${ }^{166}$ See Tessa Morris-Suzuki, Re-Inventing Japan: Time, Space, Nation (New York: Routledge, 1998) and Gregory Sullivan, "The Instinctual Nation-State: Non-Darwinian Theories, State Science and UltraNationalism in Oka Asajirō's 'Evolution and Human Life," Journal of the History of Biology 44:3 (2011).
} 
nationalistic spirit believed to unite a national group. ${ }^{167}$ From about the 1880 s to the start of the postwar period, debates on Japanese national character took on highly racialized forms through which scholars and elites of all stripes reflected on the state of the Yamato minzoku (the Japanese race), ${ }^{168}$ and, according to Oguma Eiji, national polity theorists tended to espouse views celebrating the cultural "homogeneity" and racially "pure blood" of Japan. ${ }^{169}$ Inoue Tetsujirō was one early proponent who disagreed with the idea of racial mixing and opposed mixed residence with foreigners on the curious basis that "most Japanese people are inferior to Western people in intelligence, wealth, physical constitution and in all other things, so it is inevitable that they will lose any competition." ${ }^{170}$ Inoue also argued that racial homogeneity was essential to national strength, and imagined Japanese would face a similar fate to "the Ezo [Ainu] of Japan" in that "when an inferior race resides together with a superior race...they are eventually overcome by the superior race."171 As we can see here, Darwinism, Spencerism, and scientific racism had by this point infiltrated Japanese discussions of national identity, governance, and diplomacy.

\footnotetext{
${ }^{167}$ Today, jinshu is typically translated as "race" and minzoku as "ethnic group," although throughout modern Japanese history the two terms have been used interchangeably. This characterization is not without some merit, however, as the former term entered the Japanese lexicon in the late Edo period and was used to describe the ideas of Western scientific racism, while the latter term entered the language in the early decades of the Meiji period and was applied to political and nationalist writing. By the end of the nineteenth century, minzoku had become the more common term to describe both "race" and "ethnicity," though jinsh $u$ continued to be used in specialized academic writing.

168 “Yamato" (classical: 大倭; modern: 大和) being one of several names used to describe Japan in antiquity. In the Meiji period its use harkened back to the ancient period of direct rule by the emperors.

${ }^{169}$ Oguma, Genealogy, 33-52.

${ }^{170}$ Inoue Tetsujirō, Naichi zakkyoron (Tokyo: Tetsugaku shoin, 1889), 10. National Diet Library Digital Collections: http://dl.ndl.go.jp/info:ndljp/pid/785729.

${ }^{171}$ Ibid., 49-51. National Diet Library Digital Collections: http://dl.ndl.go.jp/info:ndljp/pid/785729.
} 
Oka Asajirō (1866-1944), then Japan's leading authority on evolutionary biology, perhaps best articulated the martial spirit of the age through his fusion of kokutai ideology and its claims of Japanese racial purity with the ideas of Darwin and Spencer in his popular Shinkaron to jinsei (Evolution and Human Life) (1906) in which he described the minzoku as a sort of super organism that drove the process of human evolution as races and nations engaged in violent competition on the world stage. Oka saw Japan's wars with China and Russia, and the imperialistic endeavors that followed, as manifestations of the principles of evolution, arguing that Japan would have to continue on a path of "endless wars without end" to ensure its "racial survival."172 Katō Hiroyuki was yet another major advocate of the national polity theory who argued that Japan's victory in the Sino-Japanese War was at heart the triumph of "fraternal brethren" belonging to "one homogenous nation" over a multi-national China that that lacked racial and cultural unity. ${ }^{173}$ Inoue followed this logic during the Russo-Japanese War a decade later arguing that Russia's ethnic diversity was a liability, as "no other country has managed to maintain a racial purity like Japan.. ${ }^{174}$ Interestingly, Tsuboi predicted Japan's victory from the opposite perspective, declaring: "Japan will win because of its heterogeneity." 175 Japan, he argued, was more ethnically diverse, being composed of four types (Mongolian, Malay, European, and Ainu) while Russia only had two (Slavic peoples to the west and Mongolian peoples to the east). He compared Japan to Britain,

\footnotetext{
${ }^{172}$ Oka Asajirō, Shinka to jinsei (Tokyo: Yuseido shuppan, 1968), 87, 91. The first edition published in 1906 can be accessed here: http://dl.ndl.go.jp/info:ndljp/pid/832190/5. Also see Sullivan, "Instinctual Nation-State," for a more thorough assessment of the significance of this work.

${ }^{173}$ Katō Hiroyuki, "Junkoku no setsugi" [1900], as cited in Oguma, Genealogy, 56.

${ }^{174}$ Inoue Tetsujirō, "Bunmeishijō yori mitaru Nippon senshō no genin," Tōyō gakugei zasshi 22:283 (1905), 179. (Waseda University Central Library).

${ }^{175}$ Tsuboi Shōgorō, "Jinruigakuteki chishiki no yō masumasu fukashi," Tōkyō jinruigakkai zasshi 20:233 (1905), 462.
} 
then the world's preeminent nation, in its mixture of numerous ethnic peoples (Angles, Saxons, Celts, Normans, and Danes) and argued that ethnic and racial diversity was crucial to national development and strength. It is important that we note the difference between the reflexive sonnō jōi (revere the emperor, expel the barbarians) nativist movement that gripped Japan during the tumultuous transition from the Edo to the Meiji period from the national polity theorists, who no doubt expressed a particular brand of chauvinistic nationalism, but one absent reactionary anti-Western xenophobia. Inoue and Katō had both studied in Europe and were strong supporters of applying Western knowledge, methodology, and technology to nearly all aspects of Japanese society. Nor was it the case that national polity theorists were necessarily pro-imperialism, though most were, as were the majority of mixed-race nation theorists.

In general, the nexus of Meiji oligarchs in government and industry, academic elites, and high-ranking members of the military and colonial administration subscribed to the mixed-race nation view, and their ideas reached the Japanese public through a multitude of venues. The first means by which the dialogue of race and national identity entered the Japanese public sphere was through the introduction of nationwide compulsory public education begun in 1872. Even prior to the Meiji period Japan had estimable rates of general public education and high literacy. This began in the seventeenth century with the introduction of privately funded schools run by samurai, wealthy merchants, and religious leaders used to provide moral instruction to the children of local, well-off families. By the close of the Edo period in the mid-nineteenth century there were over 30,000 such schools that educated even the children of local peasants and 
commoners. ${ }^{176}$ The modern nationalist reformers of the new Meiji era saw education as a means of instilling patriotism and support for the new state among the nation's youth, "to cooperate as if of one mind." ${ }^{\prime 17}$ In order to achieve this, students throughout Japan were instructed to demonstrate filial loyalty to the Japanese emperor, who served as the highest national symbol, and were admonished when they failed to shed their local dialects in favor of kokugo, the new 'national language' based on the particular dialect of well-off Tokyoites, or what Ueda Kazutoshi, a German-educated linguist and its principal architect, called the "spiritual blood" of the new nation. ${ }^{178}$ The biological reference here should not be overlooked, as it was during this time that "blood-based ethnicity came to delineate the symbolic boundaries of the Japanese nation," $" 179$ a condition that continues very much in Japanese debates on issues of discrimination and immigration in the present context.

It was within this highly nationalistic and conformist public education system that Japanese students likely had their first encounters with nineteenth-century concepts of race. In this, geography and history encyclopedias and textbooks played a key role. One of the key features of these texts is their use of scientific racist discourse from the West, especially Blumenbach's division of humankind into five races: Caucasian, Mongolian,

\footnotetext{
${ }^{176}$ Brian Platt, "Japanese Childhood, Modern Childhood: The Nation-State, the School, and $19^{\text {th }}$-Century Globalization," Journal of Social History 38:4 (2005), 967.

${ }^{177}$ Iwakura Tomomi, as cited in Ibid., 971 . Iwakura, a court noble, had led a major diplomatic mission to the United States from 1871-1873 of which one of the primary goals was to survey the various schools there, including standard public schools, private religious schools, schools for former slaves, and Indian schools.

${ }^{178}$ Yuko Kawai, "Deracialised Race, Obscured Racism: Japaneseness, Western and Japanese Concepts of Race, and Modalities of Racism," Japanese Studies 35:1 (2015), 31-32. Ueda is here quoted in his "Kokugo to kokka to," [1894], in Hisamatsu Sen'ichi, ed., Meiji bungaku zenshū 44 kan: Ochiai Naobumi, Ueda Kazutoshi, Haga Yaichi, and Fujioka Sakutarō shū (Tokyo: Chikuma Shobō, 1968), 110.

179 ann-elise lewallen, "Clamoring Blood': The Materiality of Belonging in Modern Ainu Identity," Critical Asian Studies 48:1 (2016), 63.
} 
Malayan, Ethiopian, and American. Blumenbach's racialist schema entered Japan through rangaku (Dutch learning) scholarship, such as Watanabe Kazan's Gaikoku jijōsho (Reports on the Conditions in Foreign Countries, 1839), although it was Fukuzawa Yukichi's Sekai kunizukushi (Account of the Countries of the World, 1869) that had the most influence having sold over a million copies to become a mainstay in the national curriculum. ${ }^{180}$ Much of the material in Sekai kunizukushi was taken from geography and history textbooks Fukuzawa collected during his travels in Europe and the United States, though, Yasuko Takezawa reminds us that Japanese translations of foreign works "did not constitute a mere mimicry of Western knowledge, but [they] involved deletions and distortions, all with a purpose." ${ }^{\prime 181}$ In the case of Fukuzawa, Western racial constructions were paired with his theories on bunmei no tōky $\bar{u}$ (stages of civilization) which divided the races of the world into four categories of civilizational development: (1) konton, or "chaos" represented indigenous peoples, such as Australian Aborigines and the Ainu; (2) banya, denoted "barbarian" nomadic peoples; (3) mikai marked "semicivilized" nations, such as China and Korea; (4) bunmeikaika referred to the "enlightened civilizations" of Europe and the United States. ${ }^{182}$

Whereas scholars in the Edo period had conceived of civilization and foreign peoples in terms of a spatial dimensions - the further from the cultural center the more exotic and uncivilized a group was thought to be-Fukuzawa influenced generations of

\footnotetext{
${ }^{180}$ See Yasuko Takezawa, “Translating and Transforming 'Race:' Early Meiji Period Textbooks," Japanese Studies 35:1 (2015), 9; Watanabe Kazan, "Gaikoku jijōsho,"[1839], in Watanabe Kazan, Takano Chōei, Sakuma Shōzan, Yokoi Shōnan, Hashimoto Sanai, ed. Satō Shōsuke, Uete Michiari, and Yamaguchi Muneyuki (Tokyo: Iwanami Shoten, 1971), 43-55; Fukuzawa Yukichi, Sekai kunizukushi, 6 vols. (Tokyo: Keiō-gijuku, 1869) https://catalog.hathitrust.org/Record/100431709.

181 Takezawa, "Translating," 6.

${ }^{182}$ See Fukuzawa Yukichi, An Outline of a Theory of Civilization [1875], trans. David A. Dilworth and G. Cameron Hurst III (New York: Columbia University Press, 2009).
} 
Japanese to view ethnic difference as a measure of underdevelopment, and non-Western and non-Japanese societies as vestiges of a more primitive stage in human history. Many Japanese textbooks in use during this period exalted Caucasian and Aryan nations, ${ }^{183}$ while trying to portray Japan, with its unity and nationalism rooted in the reverence of the emperor, as closer to the West than China, a nation that Fukuzawa felt had "earned the contempt of other countries because there were truly no people who held patriotic thoughts." ${ }^{184}$ Scholars like Fukuzawa, and later, Tsuboi Shōgōro—-who served as a social science advisor to the Japanese Ministry of Education—wielded enormous influence over the Japanese popular landscape spreading the ideas of racialized nationalism that had been incubated in the ivory tower to Japanese popular discourse.

Another important venue that connected the work of Japanese scholars of race to the public were world fairs and colonial expositions. World fairs became popular attractions in large cities in Europe and the United States in the mid-to-late nineteenth century as they catered to public curiosity on various topics, including advancement in industry and technology, art and history, and cultural exchange. It was under the umbrella of cultural exchange that anthropologists staged living peoples exhibits, or human zoos, in order to educate the viewing public on contemporaneous theories of human societal development, racial science, and the 'exotic' cultural practices of peoples around the world. Often the exhibits functioned as positivistic theaters of empire, deliberately

\footnotetext{
${ }^{183}$ Akiyama Tsunetarō's Hyakka zensho jinshu-hen [An Encyclopdia of Race, 1874] was a translation of a chapter on the racial history of mankind taken from the popular British textbook Chamber's Information for the People, which contained the theories of popular scientific racists like Johann Blumenbach, Georges Cuvier, and James Prichard.

${ }^{184}$ Fukuzawa, Sekai, 97.
} 
displaying colonized indigenous peoples on a continuum of human development somewhere between the family of apes and "civilized" societies.

Japanese academicians entered this arena as western scholarly interest in the Ainu grew in the 1870s and 1880s. The first major Ainu exhibits took place at the Viennese World Exposition in 1873 and at Washington D.C.'s Smithsonian museum in 1890 though these only showcased collections of Ainu arts and crafts not living subjects. The racial implications of the displays were evident, however. Romyn Hitchcock, curator and collector for the Smithsonian exhibit, compared the "two distinct races," Japanese and Ainu, the former "superior and powerful," the latter "degraded and weak," and lamented that after centuries of intimate contact the Ainu "remain distinct and apart, and are therefore doomed to extinction from the face of the earth." ${ }^{, 185}$ Such was the Western view concerning the fate of indigenous peoples the world over, as their struggles in the face of epidemics, environmental destruction, systematic violence and discrimination, and forced cultural assimilation — the true causes of their demographic challenges—-were disregarded in favor of facile explanations for their suffering rooted in the theoretical imperatives of social Darwinism and scientific racism. Even John Batchelor, perhaps the most passionate advocate of Ainu welfare, could not view the Ainu apart from the Western ethnographic gaze, lamenting that "nothing now can avert their doom...they will depart without having left any history or having made any perceptible mark in the world," adding that "[o]ne feels sorry for them, but the laws of nature are inexorable and must take their course." ${ }^{, 186}$ In truth, the Ainu population was experiencing a rebound as the

\footnotetext{
${ }^{185}$ Romyn Hitchcock, The Ainos of Yezo, Japan (Washington D.C., Smithsonian Institution: Government Printing Office, 1891), 433.

${ }^{186}$ John Batchelor, Ainu Life and Lore: Echoes of a Departing Race (Tokyo: Kyōbunkan, 1927), 5.
} 
leading authoritative voices in the field of Ainu research were busy writing their obituaries, but this inconvenient fact was subsumed by academic and political narratives that required an assemblage of identifiable losers in order to exalt the supposed victors among the races and nations of humankind.

\section{Conclusion}

It was through such anthropological discourse that the image of the Ainu as a "dying race" (horobiyuku minzoku) and an "inferior race" (rettō jinshu) proliferated in Japanese society. Of course, if the Ainu were losers in this Darwinian competition for survival, then the Japanese could count themselves among humanity's racial victors, and so they did. Japanese military victories and overseas expansion raised nationalistic fervor to new heights, just as Japanese academics expanded their inquiries into the racial dynamics of their expanding empire. In this way, anthropological study went hand in hand with imperialism. New studies were facilitated by the penetration of Japanese colonial administration deep into new territories, by government- and industry-sponsored research funding, as well as the formation of new imperial universities in Taipei and Seoul. The career of Torii Ryūzō (1870-1953), a protégé of Tsuboi, is indicative of the intimacy between anthropological research and imperial expansion; he conducted studies in the Liatong peninsula and Taiwan after the Sino-Japanese War, and then in Manchuria and Korea following Japan’s victory over Russia. ${ }^{187}$

\footnotetext{
${ }^{187}$ David Askew, "Debating the 'Japanese' Race in Meiji Japan: Toward a History of Early Japanese Anthropology," in The Making of Anthropology in East and Southeast Asia, ed., Shinji Yamashita, Joseph Bosco, and Jeremy Seymour Eades (New York: Berghahn, 2004), 60.
} 
Tsuboi's notorious Hall of Mankind (Jinruikan) at the 1903 Fifth Industrial Exposition at Osaka threw this new reality into sharp relief. Tsuboi's intention was to recreate the living peoples exhibits that had become mainstays at world fairs since the 1889 Paris Exposition as a means of educating the Japanese public about the various peoples being brought under Japanese imperial sovereignty, and he planned fill these exhibits with Chinese, Koreans, Ryūkyūans, Taiwanese aborigines, in addition to Ainu subjects. Intense political opposition, however, from Chinese and Korean activists who objected to the humiliation of being displayed as primitives meant that he had to content himself with five Ainu, four Taiwanese aborigines, and two Ryūkyūans. Even so, the anthropological exhibition was a successful draw for the 4.3 million people who attended the exposition. ${ }^{188}$ The 1910 joint Japanese-British exhibition in London was an even more celebratory affair following Japan's defeat of Russia. ${ }^{189}$ Six million visitors bore witness to the Japanese exhibit that showcased Taiwanese aborigines and Ainu next to cannons used at the Battle of Port Arthur to display their nation's growing imperial reach, as well as the Yamato race's mastery over its indigenous populations, especially the Ainu, a people that, according to the Western racialist discourse of the era, were imagined as biological members of a "superior" Caucasian race, but who, like China and Russia, had been subjugated by an ascendant Japanese empire.

\footnotetext{
${ }^{188}$ Yamaji Katsuhiko, Kindai Nihon no shokuminchi hakurankai (Tokyo: Fūkyōsha, 2008), 49; Michael Weiner, "The Invention of Identity: Race and Nation in Pre-war Japan," in The Construction of Racial Identities in China and Japan, ed., Frank Dikötter, (Hong Kong: Hong Kong University Press, 1997), 112 114.

${ }^{189}$ Kreiner, “The European,” 130.
} 


\section{Chapter 3 \\ The Creative Destruction of Ainu Identities: Assimilation, Resistance, Revitalization}

On February 15, 2019, the Act on Promoting Measures to Realize a Society in Which the Pride of the Ainu People Is Respected, ${ }^{190}$ a landmark bill declaring the indigenous status of the Ainu, was taken up for review by the Japanese Diet. The bill, which passed and became law on April 26, 2019, had been years in the making following the Japanese government's adoption of the United Nations Declaration on the Rights of Indigenous Peoples (2007). ${ }^{191}$ Since becoming a member state of the United Nations in 1956, Japanese state actors have used their formal participation to articulate their nation's postwar identity as a democratic and pacifistic nation and have long incorporated the organization's goals into the central tenets of its foreign policy, a fact that has made successive Japanese administrations especially sensitive to criticism within the UN. After signing the Declaration, the Japanese government came under increased international pressure to come to terms with its history of mistreatment of its own indigenous people. ${ }^{192}$ The Diet's initial attempt to rectify this—-the Act on the Promotion of Ainu Culture, and Dissemination and Enlightenment of Knowledge about Ainu Tradition $(1997)^{193}$ — upended over a century of racist assimilation policies, and although it

\footnotetext{
${ }^{190}$ Japan Diet, Ainu no hitobito no hokori ga sonchō sareru shakai wo jitsugen suru tame no shisaku no suishin ni kan suru hōritsu [Act on Promoting Measures to Realize a Society in Which the Pride of the Ainu is Respected], $198^{\text {th }}$ Diet, No.24, 2019. The details of the law can be viewed here: http://www.shugiin.go.jp/internet/itdb gian.nsf/html/gian/honbun/houan/g19809024.htm. ${ }^{191}$ Hereafter referred to as UNDRIP. See United Nations General Assembly, Resolution 61/295, United Nations Declaration on the Rights of Indigenous Peoples, sixty-first session (September 13, 2007).

${ }^{192}$ In 2008, in response to the signing of the UNDRIP, both houses of the Diet issued the largely symbolic Ainu minzoku wo senjüminzoku to suru koto wo mitomeru kokkai ketsugi [Diet Resolution Calling for the Recognition of the Ainu People as an Indigenous People], 169th Diet, Res. 1, 2008. It is important to note that this was not a binding law, hence the importance of the 2019 legislation.

${ }^{193}$ Japan Diet, Ainu bunka no shinkō narabi ni Ainu no dentō tō ni kan suru chishiki no fukyū oyobi keihatsu ni kan suru hōritsu [Act on the Promotion of Ainu Culture, and Dissemination and Englightenment of Knowledge about Ainu Tradition], $140^{\text {th }}$ Diet, No. 52, 1997. It is commonly referred to
} 
accepted the existence of the Ainu as an "ethnic minority," the measure stopped short of recognizing their indigeneity to northern Japan, a position already widely acknowledged within the international community.

The 2019 law is a recent attempt by Japanese policymakers to address this international scrutiny. While the Diet deliberated on the new bill, many in government and media emphasized its glossy promises: long overdue acceptance of Ainu indigeneity; a new Ainu museum set to open in April, 2020, just ahead of the Tokyo Olympics; one billion yen earmarked for Ainu cultural revitalization projects; and new scholarships for Ainu youth to study their ancestral language and culture. Many observers failed to notice, however, the historical wounds that threatened to rupture and divide Ainu people's responses to the new legislation.

On March 3, roughly a hundred protestors, many from small Ainu communities excluded from the Japanese government's drafting of the law, took to the streets of Sapporo, Hokkaido, to demand the bill's retraction. ${ }^{194}$ They pointed to its inadequacies in addressing fundamental questions of indigenous land and cultural rights. For instance, the new law permits Ainu people to fish in local rivers and gather timber in national forests, but only after requesting permission through an arcane system within Japan's byzantine bureaucracy. They argue that this legal arrangement is firmly at odds with the UNDRIP, and out of step with the domestic policies of other signatory nations where indigenous peoples' autonomy and independent sovereignty are affirmed. At a press conference just

as the Ainu Shinpō (Ainu New Law).

${ }^{194}$ Saito Chie, "Senjūken no hoshō wo Ainu minzoku dantai ga shūkai" [Ainu groups gather to secure indigenous rights], Hokkaido Shimbun, March 4, 2019. https://www.hokkaido-np.co.jp/article/282580 
before the protest, Shimizu Yūji, head of the Kotan no kai (Kotan Association) ${ }^{195}$ an organization that has emerged from the controversy and given voice to the bill's most ardent detractors, made another, perhaps more poignant, observation.

While the Japanese government appeared eager to at least pay lip service to a number of the unique challenges impacting their nation's newly embraced indigenous minority, it came up short in one crucial area: Atonement for its past sins committed against them. As Shimizu artfully articulated: "The Japanese forcibly colonized us and annihilated our culture. Without even admitting to this, they want to turn us into a museum exhibit." 196 And here is where an examination of the historical legacy of Ainu trauma becomes essential for understanding the aspirations and concerns of Ainu people today.

In recent years, Kotan no kai, a diminutive organization representing a few dozen Ainu members mostly located in the Hidaka region, has been involved in several successful lawsuits with Hokkaido University, Sapporo Medical University, and other research institutions over the repatriation of Ainu remains appropriated from local gravesites, a cause that has rapidly become the group's raison d'être. One area of controversy in the new law is its promise to "return" up to 2,300 boxes of Ainu remains scattered in museum and university collections throughout Japan to a recently constructed ossuary at the heart of the new Ainu museum complex. ${ }^{197}$ Kotan no kai argues that the

\footnotetext{
${ }^{195}$ The term kotan means "village" or "settlement" in the Ainu language and was the primary method of Ainu social and communal organization before the Meiji government disbanded them in the late nineteenth century.

${ }^{196}$ Emiko Jozuka, “Japan's 'Vanishing' Ainu Will Finally be Recognized as Indigenous People” CNN, April 23, 2019. https://edition.ads.next.cnn.com/2019/04/20/asia/japan-ainu-indigenous-peoples-billintl/index.html.

${ }^{197}$ Kayoko Kimura, “Japan's Indigenous Ainu Sue to Bring Their Ancestors' Bones Back Home," The Japan Times, July 25, 2018. https://www.japantimes.co.jp/news/2018/07/25/national/japans-indigenousainu-sue-bring-ancestors-bones-back-home/\#.Xa4XiJMzaFU
} 
remains should be returned with proper rites and ceremonies to the earth nearest to where they were excavated. Morris-Suzuki expertly summarizes this viewpoint: "For them, the idea that Ainu remains are to be 'repatriated' to a concrete mausoleum in a major tourism complex...is anathema, and is indeed not repatriation at all, but merely the shifting of the dead from one alien space to another." ${ }^{, 198}$ A further point of contention is the government's plan to make the Ainu remains in question available to future academic researchers.

The Hokkaidō Ainu kyōkai (Ainu Association of Hokkaido; AAH), the largest Ainu organization in Japan, as well as many of the forty-nine district-level Ainu associations have come out in support of the new law, despite its limitations, viewing it as a major step forward. ${ }^{199}$ The leaders of the AAH argue that the transfer of the remains to the new museum is a small price to pay for the various economic incentives and cultural protections promised by the Japanese government. Many within these groups view the increase in Ainu-related tourism positively and believe the transfer of remains to the museum, while far from ideal, to be an acceptable outcome. Critics of the AAH's position, on the other hand, insist that the new law helps the government brush aside serious concerns about the challenges facing contemporary Ainu individuals and communities, concealing them behind the lofty tourism goals the government has set for the year 2020, when it hopes the Tokyo Summer Olympics and attractions like the new Ainu museum will lure in at least forty million international visitors. ${ }^{200}$

\footnotetext{
198 Tessa Morris-Suzuki, "Performing Ethnic Harmony: The Japanese Government's Plans for a New Ainu Law," The Asia-Pacific Journal: Japan Focus 16:21:2, (November, 2018), 9.

199 Kimura, The Japan Times, "Japan's indigenous Ainu."

200 The Japanese government hopes to draw one million tourists to the new Ainu museum complex in its inaugural year. "Bill Finally Recognizes Ainu as Indigenous People of Japan," The Asahi Shimbun,
} 
This current debate over the role of tourism in Ainu affairs can appear mystifying to those without historical knowledge of its complexities. In this chapter, I examine the impact of the Japanese government's attempts to eliminate Ainu cultural identities through comprehensive assimilation programs, and its history of using ahistorical and racist descriptions of the Ainu to promote Hokkaido tourism, but also how many Ainu used political activism and their role as cultural arbiters to preserve and to revitalize a culture long thought to be lurching toward the edge of extinction.

\section{Early Modern Origins of Ainu Subjugation and Assimilation}

The prevailing historical narrative of the island of Hokkaido — at least among the general Japanese public — has long celebrated the 'development' (kaitaku) of present-day Japan's northernmost island by intrepid pioneers from the mainland who settled and tamed a cold, unforgiving 'no-man's land' in the closing decades of the nineteenth century. This is a typical settler colonialist account, of course, that obscures the Ainu's unique role in the island's history and, by extension, that of the Japanese nation.

During the earliest stages of Japanese settlement on Ezochi (present-day Hokkaido), in the fourteenth and fifteenth centuries, the Ainu were well positioned at the crossroads of important trade routes connecting continental northeast Asia with the Japanese island of Honshu. In 1604, however, the Tokugawa Shogunate's grant of trading rights with the Ainu to the Matsumae clan altered this balance of trade. ${ }^{201}$ The Matsumae were able to

February 6, 2019.

${ }^{201}$ Takakura Shinichirō, The Ainu of Northern Japan: A Study in Conquest and Acculturation, trans. John A. Harrison (Philadelphia: American Philosophical Society, 1960), 27-29. 
use their small political base on the southern tip of Ezo along with the expansion of commercial fisheries and mining operations to exert greater control over the terms of trade with disparate Ainu kotan (villages). ${ }^{202}$ In 1669, Shakushain, the powerful chieftain of the Menashunkur Ainu, managed to unite many independent Ainu communities in a campaign to break the growing Matsumae stranglehold on Ainu-Japanese commerce, though they could not overcome the military resources of the Shogunate. Shakushain fell victim to Japanese assassins during feigned peace negotiations, and in the conflict's aftermath Ainu trade autonomy vanished as even the most remote kotan grew increasingly dependent on Matsumae-aligned Japanese merchants to acquire important trade goods, such as iron tools, rice, sake, cotton clothing, and lacquerware. ${ }^{203}$

Ainu labor in highly exploitative commercial fisheries soon became the principal economic activity on Ezochi, and by the early eighteenth century there were seventy Japanese trading posts dotting its coastline, each dominated by market forces and major merchant houses from mainland Japan. By 1740, the basho ukeoi (subcontracted trading post) system was supplying more than half of the wet-rice paddies in distant western Japan with Ezo-produced herring fertilizer. ${ }^{204}$ Merchant contractors who operated the trading posts faced significant financial risks, as well as high taxes, fees, and forced loans to the Matsumae clan, an arrangement that placed them under intense pressure to extract as much labor as possible from Ainu workers in order to turn a profit. The commercial fishery system concentrated Ainu from many different kotan together—often through

\footnotetext{
${ }^{202}$ Ainu were not a politically unified group, but a collection of disparate and independent communities sharing some elements of a shared culture.

${ }^{203}$ Brett L. Walker, The Conquest of Ainu Lands: Ecology and Culture in Japanese Expansion, 1590-1800 (Berkeley: University of California Press, 2001), 48-72.

${ }^{204}$ Richard Siddle, Race, Resistance and the Ainu of Japan (New York: Routledge, 1996), 36. 
various forms of coercion —into seasonal, sometimes permanent, worker camps where they toiled under degrading conditions in which physical and sexual abuse were frequent, and smallpox and measles epidemics occurred at alarming rates. ${ }^{205}$ The dependence on Ainu labor irreparably damaged their subsistence patterns. Overfishing reduced populations of salmon and other fish crucial to the Ainu diet, while the demands of the fisheries forced growing numbers of Ainu laborers away from their communities for longer durations. Those who remained in the kotan were often young, infirm, or elderly people incapable of carrying out the hunter-gathering tasks necessary to feed their communites.

Japanese observers in the eighteenth and early-to-mid nineteenth centuries commented on the negative demographic effects these conditions had wrought upon the Ainu. Matsuura Takeshirō, an explorer who participated in numerous expeditions to Ezochi on behalf of the shogunate, wrote that between 1808 and 1857 the population of Nemuro at the island's northeastern corner had declined by more than half, from 1,219 to 581 persons, while some of the smaller kotan in the area had either vanished or were inhabited solely by those unfit for labor at the fisheries. ${ }^{206} \mathrm{He}$ recorded this during a period in which the bakufu had sent officials and doctors north to Ezochi to gauge Ainu living conditions, provide them with medicine and vaccines, and entice them into assimilation to Japanese culture. The bakufu's 1857 vaccination project and cultural

\footnotetext{
${ }^{205}$ David L. Howell, "The Ainu and the Early Modern Japanese State, 1600-1868," in Ainu: Sprit of a Norther People, ed. William W. Fitzhugh and Chisato O. Dubreuil (Washington D.C., Smithsonian Institution, 1999), 100. Howell notes that some of the more popular contemporary Ainu tourist areas, such as Shiraoi, were originally the sites of worker camps near commercial fisheries.

${ }^{206}$ Kikuchi Isao, Hoppōshi no naka no kinsei Nihon [Early Modern Japan in Northern History] (Tokyo: Azekura shobō, 1991), 124-125.
} 
assimilation schemes were premodern attempts at Foucauldian biopolitics, the efforts of states to reconfigure relations with individuals and communities within their boundaries through public health and hygiene campaigns, and through the policing of bodies. ${ }^{207}$ Walker argues that the vaccination program was a product of the bakufu's reimagining of territorial and cultural space whereby Ezochi and the Ainu living there were no longer viewed as peripheral, but rather a part of Japan itself. ${ }^{208}$

Naturally, geopolitical strategy lay at the core of the bakufu's efforts to foster deeper linkages to Ainu communities; here the bakufu's initial efforts to assimilate the Ainu are particularly instructive. The bakufu first sent officials north on these assimilation missions between 1791 and 1821 after hearing reports of Russian encroachment into Ainu lands in Sakhalin, the Kuriles, and Ezochi. Russian traders, soldiers, and missionaries had established a network of trading posts stretching from the continent at Kamchatka to the Kurile Islands just north of Ezochi, and some Ainu communities began to adopt Russian names, Western-style dress, and converted to the Orthodox faith. ${ }^{209}$ Bakufu officials sought to counter Russian penetration into Ezo by seizing administrative control of Wajinchi territory from the Matsumae clan, ordering cartographic surveys of Ainu lands, ${ }^{210}$ and by extending buika ('benevolent' governance) to the Ainu, in effect

\footnotetext{
${ }^{207}$ See Michel Foucault, The Birth of Biopolitics: Lectures at the Collège De France 1978-1979, ed. Michel Senellart, trans. Graham Burchell (New York: Palgrave MacMillan, 2008). I examine the Jennerian vaccination program as a mode of premodern biopolitics in greater depth in chapter one.

${ }^{208}$ Brett L. Walker, "The Early Modern Japanese State and Ainu Vaccinations: Redefining the Body Politic 1799-1868," Past \& Present 163 (1999), 156-160.

${ }^{209}$ Donald Keene, The Japanese Discovery of Europe: Honda Toshiaki and Other Discovers 1720-1798 (Stanford: Stanford University Press, 1969), 41-47; Tessa Morris-Suzuki, Re-Inventing Japan: Time, Space, Nation (New York: Routledge, 1998), 21.

${ }^{210}$ Brett L. Walker, "Mamiya Rinzō and the Japanese Exploration of Sakhalin Island: Cartography and Empire," Journal of Historical Geography 33 (2007), 282-313.
} 
attempting to bring them into the political and cultural bounds of the Japanese state through moral and cultural persuasion.

In the minds of the officials, conceptualizations of difference between Japanese and cultural Others were shaped not in terms of race or ethnicity per se, rather they were understood according to ka-i shisō (thoughts on civilization and barbarism), ${ }^{211}$ a worldview adopted from the ancient Chinese tribute system that imagined civilization blossoming from the political center; the farther one ventured from this center the more uncivilized things became with poverty, disease, and disorder arising out of this physical and cultural distance. ${ }^{212}$ Howell explains that Tokugawa authorities were more "concerned with exteriority - the visible compliance with norms - than with the internalization of the principles behind those norms."213 In other words, the early efforts to assimilate the Ainu were predicated on the belief that by merely swapping Ainu customs with those of the Japanese not only would the Ainu become, in effect, like the Japanese, but this would bring to an end the penury and pestilence they continued to suffer.

Some Ainu did voluntarily undergo assimilation, shaving their beards, tying up their hair, and putting on Japanese-style clothing and straw sandals in exchange for material rewards in the form of foodstuffs, sake, craft items, and money. In some areas, public ceremonies were held to "celebrate the improvement of customs" (kaizoku no gi)

\footnotetext{
211 "Barbarism" in premodern Japan was not conceived of in ethnic or racial terms, but as a matter of cultural form, such as in the case of those "who write using an alphabet and do not know Chinese characters, and who do not use chopsticks, but eat with their hands." Terajima Ryōan, Wakan sansai zue [Illustrated Sino-Japanese Encyclopedia] (1712). Quoted in David L. Howell, Geographies of Identity in Nineteenth-Century Japan (Berkeley: University of California Press, 2005), 138.

${ }^{212}$ Morris-Suzuki, Re-Inventing, 17-20.

${ }^{213}$ Howell, Geographies, 16.
} 
whereby Ainu participants were "paraded in their new costume, treated to Japanese-style banquets, and sometimes presented with 'assimilation medals' (kaizoku hai)."214

Observers noted that most Ainu deliberately hid in the mountains when bakufu officials arrived rather than offend their ancestors and gods by becoming Wajin. ${ }^{215}$ Many who had consented to being party to this assimilation pageantry would often wait for bakufu officials to leave, then simply change back into their original clothes, grow their beards, and once again live as Ainu.

Still, the conditions of Ainu identity at the time were rather complex, as many Ainu were already of mixed Wajin-Ainu descent, and many kotan had a tradition of adopting abandoned Wajin children whom they raised as Ainu. Some individuals, such as Iwanosuke, an Ainu leader of Kennichi village in the eighteenth century—before the assimilation programs began—openly experimented with the adoption of Japanese cultural norms. Iwanosuke, himself, resided most of the year in a Wajin village, had a Japanese name, was typically clean-shaven, and wore his hair and clothing according to popular Japanese fashion. Japanese observers noted that for a brief period each year he would let his beard grow long for the purpose of attending the uimam with the Matsumae lord after which point he transitioned seamlessly back to his adopted Wajin life. ${ }^{216}$ The Matsumae clan, in fact, strictly enforced prohibitions on such activities to prevent Ainu from speaking Japanese, practicing farming, and wearing Japanese garments. Moreover,

\footnotetext{
${ }^{214}$ Morris-Suzuki, Re-Inventing Japan, 22, and Kikuchi, Hoppōshi, 11-13.

215 Takakura Shinichirō, Ainu seisakushi (Tokyo: Nihon Hyōronsha, 1943), 382-383. http://dl.ndl.go.jp/info:ndljp/pid/1270068 and Howell, Geographies, 147.

${ }^{216}$ Mogami Tokunai, "Ezo no kuni fūzoku ninjō no sata," [Report on the Common Customs of Ezo] in Nihon shomin seikatsu shiryō shūsei: Tanken, kikō, chishi hakuhenhen ed. Takakura Shinichirō, vol.4 (Tokyo: Sanichi Shobō, 1969), 445. See also Howell, Geographies, 119.
} 
through political ceremonies such as the $\operatorname{uimam}^{217}$ Matsumae rulers regulated the dress of Ainu chiefs in such a way as to magnify the visual impact of perceived Ainu exotica and delineate stark cultural boundaries between the two peoples. Ainu chiefs and their entourages were expected to pay tribute to Matsumae lords while clad in furs, Manchurian silks, impressively long beards, and accompanied by dogs and exotic animals.

The bakufu abandoned this governing strategy as vessels from Europe and the United States journeyed ever nearer to their shores. Their fears were soon realized in 1853 with the arrival of Commodore Perry's 'black ships' in Edo bay. Under threat of military force, Perry demanded Japan enter into an unequal trade agreement with the United States, and similar requests soon followed from a host of other Western nations. Although the general public was jarred by the sudden arrival of foreign peoples on their shores, bakufu officials had decades earlier sponsored the creation of modern maps, and they were able to deploy these as well as their existing relations with foreign Others on the periphery - the Ainu to the north and the Ryūkyū kingdom to the south — to increase their national territory. ${ }^{218}$ The bakufu used its attempted assimilation of the Ainu as leverage in negotiations with the Russian Empire, and was able to stake territorial claims over Ainu lands by insisting that they were a protected people under the suzerainty of the Japanese state. By way of example, we can look to Japan's negotiating strategy with Russia for the Treaty of Shimoda (1855). During these talks, the Russian envoy disputed

\footnotetext{
${ }^{217}$ Matsumae lords interpreted the uimam ceremony whereby Ainu chieftains would pay annual visits to Fukuyama castle as a form of official tribute. For Ainu leaders, on the other hand, it was simply an acknowledgement of their mutual trade relationship.

${ }^{218}$ Oguma Eiji, The Boundaries of 'the Japanese': Korea, Taiwan and the Ainu 1868-1945, vol. 2, trans. Leonie R. Stickland (Melbourne: Trans Pacific Press, 2017), 16-17.
} 
Japanese claims over the Kurile Islands insisting that "only Ainu live there," a claim the Japanese envoy rebuffed: "Aino [sic] means Ezo people; and because the Ezo are people

who belong to Japan, places where Aino reside are, in other words, Japanese territory."219 The signing of the treaty established the international recognition of Japan's dominion over the Ainu, an outcome shaped by the early modern Japanese state's attempts to subjugate and assimilate them.

\section{Restoration and Relocation}

The Meiji Restoration of 1868 changed Japanese life beyond recognition for people at all levels of society, as it did tragically for the Ainu as well. This transition away from the Tokugawa feudal state manifested in syncretic forms of social and political organization, along with new ways of conceptualizing the body-politic, the relationship between the state and the people, and national ideology and identity. Meiji policymakers achieved this through the creation of a Prussian-style constitution and bureaucracy, the standardization of national education and language, and the "invented traditions" of Kokka Shintō (State Shinto). While they looked 'West' for instruction in modernity, they also gazed 'East' borrowing from Confucianism the idea of the 'family state' with the emperor as the spiritual 'father' of the nascent nation, merging this with the German concept of 'Volk' (the ethno-cultural nation; minzoku in Japanese). ${ }^{220}$ In this period of rapid change and

\footnotetext{
${ }^{219}$ As cited in Ibid., 17.

${ }^{220}$ See John W. Dower, War Without Mercy: Race and Power in the Pacific War (New York: Pantheon Books, 1986), Carol Gluck, Japan's Modern Myths: Ideology in the Late Meiji Period (Princeton: Princeton University Press, 1987), Marius B. Jansen, The Making of Modern Japan (Cambridge: Harvard University Press, 2002), and Donald Keene, Emperor of Japan: Meiji and His World, 1852-1912 (New York: Columbia University Press, 2005).
} 
destabilization, as Japan sought to strengthen its military and economy and raise its status in the Western-dominated diplomatic order, the Japanese monarchy_rather the "modern myths" 221 invented to legitimize it — acted as nucleus, binding unfamiliar ideas, institutions, and social practices to an essentialized national past, a shared ethno-cultural identity.

Central to this new "imagined community"222 was the recently imported idea of 'Race.' As Dower reminds us: "The half century or more during which the Japanese initially turned to the West for education coincided almost exactly with the period when scientific racism dominated the natural and social sciences in Europe and the United States."223 Japan's widespread adoption of scientific racism in the Meiji period helped lay the foundation of its policies of colonial oppression, a fact we must take into account when examining contemporary Ainu resistance, in their struggle for rights and recognition, and to preserve and pass along their culture to future generations.

The Meiji government formally annexed Ezo in 1869 renaming it Hokkaidō (Northern Sea Circuit). The government then placed the territory under the control of the Kaitakushi (Colonization Commission) ${ }^{224}$ and hired foreign advisors like Horace Capron, the former U.S. Commissioner of Agriculture, to oversee the island's economic

\footnotetext{
${ }^{221}$ These included ideas such as the divinity of the unbroken 1,500-year-old imperial line, and the notion of the imperial descent of the Yamato race (Japanese race), which was believed to engender a unique organic and spiritual bond between the Japanese public and its monarch.

${ }^{222}$ Benedict Anderson, Imagined Communities: Reflections on the Origin and Spread of Nationalism (New York: Verso, 2006).

223 John Dower, War Without Mercy, 204.

224 'Kaitakushi' has most often been translated as 'development commission,' though contemporary scholars have also referred to it as the 'colonization commission' to draw attention to the history of AinuJapanese relations and because its activities were centered on imperialistic goals. The use of "development," although an accurate translation of the term 'kaitaku,' is no doubt euphemistic in an historical sense.
} 
development. Hokkaido became the center of Meiji Japan's experiments in new agricultural and pastoral techniques, home to scientific farms testing new crops and expansive ranches housing horses, pigs, sheep, and especially cattle, all in a nation that had long viewed eating meat as a violation of religious taboos. ${ }^{225}$ Meiji officials understood the role cattle ranching, in particular, had played in expanding settlement across the American West and how this was challenged by Native American resistance. Some of the Kaitakushi advisors hailing from the United States, including Capron himself, were directly involved in crafting aspects of the country's Native American policy, and these experiences influenced the ways in which they conceived of the Ainu: as a 'dying race,' prey to disease and starvation and losing out in a Darwinian competition for survival. ${ }^{226}$

Entirely absent from this view was any notion that Ainu poverty and lack of food security stemmed from ecological damage that worsened as colonial structures on the island became more deeply entrenched. A steady flow of new immigrants from the Japanese mainland and the Kaitakushi's own development policies led to the destruction of food sources necessary for Ainu subsistence. Commercial fishing and mining damaged rivers and caused severe disruption to salmon runs, and the demand for canned venison exports drove rifle-armed Japanese hunting parties deep into Ainu lands within Hokkaido's interior where by 1878 , they hunted Hokkaido's deer to the verge of

\footnotetext{
${ }^{225}$ Bans on eating meat had existed since 675 following the growth of Buddhist influence on the imperial court. The Tokugawa shogunate issued its own ban on the eating of domesticated animals in 1687, though this exempted the hunting and eating of game animals and fish. After it became widely publicized that the Meiji emperor ate beef for the first time in 1872, a group of Buddhist monks stormed the imperial palace in protest. The official ban on eating meat was lifted that same year. See Tatsuya Mitsuda, "Vegetarian' Nationalism: Critiques of Meat Eating for Japanese Bodies, 1880-1938," in Culinary Nationalism in Asia, ed. Michelle T. King (New York: Bloomsbury Academic, 2019).

${ }^{226}$ William W. Fitzhugh, “Ainu Ethnicity: A History,” in Ainu: Spirit, 14-15.
} 
extinction. ${ }^{227}$ Hokkaido's deer fared better than its wolves, however. As deer populations fell wolf attacks on the Kaitakushi's experimental ranches increased, endangering Hokkaido's beef-producing venture altogether. In response, the Kaitakushi waged war on Hokkaido's wolves with an elaborate bounty system and the systematic use of strychnine to poison their dens. The result: Hokkaido's wolves were extinct by the end of the following decade. ${ }^{228}$ In addition, Japanese officials ordered the shooting of Ainu hunting dogs found near government farms and ranches. ${ }^{229}$ This was a blow to Ainu communities on two fronts - a symbolic assault on their religious beliefs due to the importance of dogs in Ainu spirituality and mythology, and an economic one as dogs were integral to Ainu hunting campaigns.

In a cruel twist, an 1871 edict had formally banned the Ainu from hunting by traditional methods (poison arrows, spring-bow traps, etc.) and outlawed Ainu cultural practices, such as tattooing, the wearing of earrings, and performance of customary funeral rites, ${ }^{230}$ although the fact that the Kaitakushi reissued these prohibitions five years later indicates that the initial law was ignored by many, primarily those communities in the interior where the government's authority and knowledge of the terrain was still weak. This changed rapidly with the passing of land reform laws, the first of which, the

${ }^{227}$ At the Tokachi basho (trading post) around 600-700 deer hides were collected annually prior to the Meiji period; In the year 1878 alone, at the same trading post, the yield was over 12,500. See Siddle, Race, 62.

${ }^{228}$ See Brett L. Walker, The Lost Wolves of Japan (Seattle: University of Washington Press, 2005): 3-23, $129-157$.

${ }^{229}$ Brett L. Walker, "Meiji Modernization, Scientific Agriculture, and the Destruction of Japan's Hokkaido Wolf," Environmental History 9:2 (2004), 260-261.

${ }^{230}$ Ainu would burn the cise (thatch hut dwelling) of the deceased to mark their departure from this life to the afterlife. A scene in the film Yurusarezaru Mono (2013), a remake of Clint Eastwood's Unforgiven (1992) set in Hokkaido in the early decades of the Meiji period shows Japanese soldiers violently humiliating an Ainu village over this practice. Meiji officials considered cise unhygienic and symbolic of Ainu 'primitiveness.' 
1873 Jisho kisoku (Land Ordinance Law), declared Hokkaido land terra nullius, in effect making Ainu-held land subject to private purchase by mainland Japanese. The 1877 Hokkaidō jiken hakkō jōrei (Ordinance for the Issuing of Hokkaido Land) compounded Ainu subjugation by putting all of their communally-held lands into the constrictive grasp of the state. ${ }^{231}$ The state's seizure of this land was made possible by the introduction of the Koseki (family registration) system, a process that required all Japanese citizens-the Ainu began to be referred to as kyūdojin (former natives) and were given the status of heimin (common citizens) of the empire - to provide detailed family and residential information to the authorities. For the Ainu, this process also entailed that they officially take Japanese names.

After the Kaitakushi was dissolved in 1882 and Ainu affairs fell first to local prefectural governments ${ }^{232}$ and later to central government control, forced relocations of Ainu communities became commonplace. Ainu kotan had historically been constructed along waterways in the interior, which provided ample access to seasonal salmon runs and extensive hunting grounds but were also home to the island's most fertile soil. Yet, the ecological damage that accompanied Hokkaido's agricultural and industrial development drove many Ainu hunters in the interior to join government survey teams; the Ainu hunters' intimate knowledge of the terrain became a crucial resource for mapping river systems and allowed colonial officials to plot out suitable areas for

\footnotetext{
${ }^{231}$ Kojina Kyōko, "The Making of Ainu Citizenship from the Viewpoint of Gender and Ethnicity," trans. Leonie Stickland, in Gender, Nation and State in Modern Japan, ed. Andrea Germer, Vera Mackie and Ulrike Wöhr (New York: Routledge, 2014), 104; Emori Susumu, Ainu no rekishi: Hokkaidō no hitobito, vol. 2 (Tokyo: Sanseidō, 1987), 111.

${ }^{232}$ The Kaitakushi was dissolved in 1882 due to a corruption scandal. Well-connected officials and businessmen were found to have been purchasing the agency's assets far below market value. After the Kaitakushi, Hokkaido was first divided into three prefectures (Sapporo, Hakodate, and Nemuro) and in 1886 the entire island was united into a single prefecture.
} 
immigrant farmers. Ainu communities were subsequently and forcibly moved off these highly arable lands and placed on hogochi (reservations), where they were forbidden from hunting and fishing and instead made to farm unfamiliar crops on substandard land. ${ }^{233}$ The process of removal was itself entirely destabilizing, as can be expected, and, predictably, many of these initial farming experiments failed leading to exacerbated levels of poverty and food shortages. Moreover, many aspects of agricultural life, such as manuring, violated Ainu religious codes, as did the inability to fish local rivers and hunt game. $^{234}$

Perhaps the most tragic incidents occurred after the signing of the Treaty of St. Petersberg in 1875 , when Russia agreed to cede control of the northern Kurile Islands to Japan in exchange for sole control over southern Sakhalin. After the signing concluded, 841 Sakhalin Ainu were relocated to Tsuishikari, a waterlogged tract of land outside of Sapporo, where approximately 350 fell victim to malnutrition, smallpox and cholera in $1886-1887 .{ }^{235}$ A similar situation occurred in 1884 to a community of 96 Christian Ainu from the Northern Kurile island of Shumushu. Siddle writes: "After being ordered to slaughter all their dogs, they were herded on board the vessel sent to transport them, and from the deck they watched their village go up in flames. ${ }^{, 236}$ Their ordeal only grew

\footnotetext{
${ }^{233}$ Siddle, Race, 66.

${ }^{234}$ Specifically, manuring went against Ainu concepts of purity, and they conceived of hunting and fishing as the release of gods and spirits trapped inside of animals. It was a religious responsibility for Ainu males to free these spirits through hunting. The popular iyomante ceremony that features a bear sacrifice is based on this same spiritual principle.

${ }^{235}$ Tsuishikari no ishibumi [The Monument of Tsuishikari], Karafuto Ainu shi kenkyūkai, ed. (Sapporo: Hokkaidō Shuppan Kikaku Sentā, 1992), 418-440; Discussed in Siddle, Race, 63-64.

${ }^{236}$ Richard Siddle, "From Assimilation to Indigenous Rights: Ainu Resistance Since 1869," in Ainu: Spirit, 108.
} 
worse after they were taken to their new home on a barren island near Hokkaido's

northeastern coast. Within five years, half of the group had perished. ${ }^{237}$

\section{Welfare Colonialism for a 'Dying Race'}

Although Ainu communities throughout Hokkaido continually faced dire conditions in the latter decades of the nineteenth century, population figures from the period indicate that, despite the poverty and epidemics they so often contended with, the overall number of Ainu on the island remained fairly stable. ${ }^{238}$ For example, the first census in 1873 counted 16,272 Ainu among 111,196 total residents, while a census thirty years later found 17,783 Ainu out of a total population of $1,077,280 .{ }^{239}$ The apparent shift in the figures presented here elucidates the extent to which mainland immigration to the island, which increased nearly tenfold during the thirty-year period, contributed to the demographic changes taking place there. In 1873, Ainu made up nearly $15 \%$ of the population and this decreased to $1.65 \%$ by 1903 ; meanwhile, the Ainu population of record actually grew by about 9\%. Evidently, Japanese and Western perceptions of the Ainu as a 'dying race' were shaped not by actual population decline, but by several other factors, including poverty in Ainu communities, the ongoing effects of disease, and

\footnotetext{
${ }^{237}$ The fact that these Ainu were followers of the Russian Orthodox church is significant given the fact that they lived near the boundary separating Japanese and Russian territory. Such people were sometimes looked upon with suspicion by Japanese authorities. Kaiho Yōko, Kindai hoppō shi: Ainu minzoku to josei to, [Modern History of the Northern Regions: The Ainu People and Women] (Tokyo: Sanichi Shobō, 1992), 444; Siddle, Race, 65; Howell, Geographies, 187-190.

${ }^{238}$ I should note that I am not arguing that the Ainu did not experience demographic decline during the early modern period. The population of Ainu in Hokkaido, the Kuriles, and Sakhalin is thought to have been approximately 40,000 at the beginning of Matsumae rule in the early seventeenth century. Between then and the late nineteenth century the combination of epidemic disease and colonial oppression did bring about a drastic demographic decline similar to those experienced by many of the world's indigenous peoples.

${ }^{239}$ Siddle, Race, 59; his table is adapted from figures cited in Emori Susumu, Ainu no rekishi, 126.
} 
preconceptions about the assumed fate of 'uncivilized' and, therefore, 'inferior races,' whose 'extinction' many held to be a biological certainty. Such figures lamented the disappearance of 'pure Ainu, ${ }^{, 240}$ meaning those who exhibited certain phenotypical Caucasoid features and adhered to 'traditional' religious and cultural practices. In truth, Ainu women had long experienced relations with Japanese men, both consensual and coercive, that resulted in the births of 'mixed-blood' children, and the adoption of abandoned Japanese children by Ainu families was commonplace. ${ }^{241}$ Furthermore, as Meiji Japan's assimilationist colonial regime grew more oppressive, Ainu communities had little choice but to comply with the cultural changes imposed on them.

The educated Meiji elite no doubt viewed Ainu poverty as evidence of racial 'inferiority’ and believed it affirmed the prevailing Western discourse in scientific racism and Social Darwinism. Despite the fact that most Japanese came to believe in the inevitability of Ainu racial extinction, a liberal humanitarian movement comprised of government officials, intellectuals, educated professionals, and foreign missionaries coalesced in an attempt to discover a solution, or at least find ways to ameliorate Ainu suffering. Tsuboi Shōgorō, the father of Japanese anthropology, and leading proponent of the "mixed-race nation" theory of Japanese origins, ${ }^{242}$ was one prominent member of the

\footnotetext{
${ }^{240}$ This term is still used today by a limited number of scholars, rightist politicians, and media personalities who continue to argue that the Ainu vanished long ago on account of there being no "pure" Ainu remaining in Japan. For examples, see Mark Winchester, "Everything You Know About Ainu is Wrong: Kobayashi Yoshimori's Excursion into Ainu Historiography," The Asia-Pacific Journal: Japan Focus 9:22:1 (2011), and ann-elise lewallen, "Human Rights and Cyber Hate Speech: The Case of the Ainu," Asia-Pacific Human Rights Information Center: Focus 81 (2015).

${ }^{241}$ This is the consensus view, but I would specifically refer readers to the work of lewallen, especially "Clamoring Blood': The Materiality of Belonging in Modern Ainu Identity," Critical Asian Studies 48:1 (2016).

${ }^{242}$ Tsuboi believed the Yamato (Japanese) race was formed over several millennia through the mixing of Ainu, Polynesian, and continental Asian peoples who had settled in prehistoric Japan. He was instrumental in education and policy circles relating to the assimilation of the Japanese empire's various ethnic and indigenous minorities.
} 
movement, often organizing charity drives and promoting Ainu welfare in the pages of the Tōkyō jinruigakkai zasshi (Tokyo Anthropological Society Magazine) and frequent public lectures. Within the Ainu welfare movement of the late nineteenth century, there was a near universal belief in the necessity of eradicating primitive Ainu lifeways through a central government-led comprehensive assimilation program. The local prefectures simply did not have the resources to, as Tsuboi described, successfully carry out the project of "educating" the Ainu, "to teach the ignorant, and to turn those who are good for nothing into useful members of society. ${ }^{243}$ By contrast, Tsuboi’s one-time colleague, Koganei Yoshikiyo, disagreed arguing that the Ainu were a "decadent race" who, despite the reformers' best efforts, “[would] eventually perish."244

Koganei's reference to decadence here likely refers to the high rates of Ainu alcoholism ${ }^{245}$ and low levels of education within Ainu communities. In these areas, Christian missionaries filled an existing void and came to play a highly significant role in the Ainu welfare movement by promoting the creation of the Hokkaido Temperance Society in 1887 and the construction of schools near Ainu villages. ${ }^{246}$ By far the most prominent among them was John Batchelor, the British reverend-cum-amateur Ainu ethnologist who arrived in Hakodate in 1877, became fluent in both Japanese and Ainu, translated the gospels into the Ainu language using Romanized spelling, and in 1892

\footnotetext{
${ }^{243}$ Tsuboi Shōgorō, "Hokkaidō kyūdojin kyūiki jigyō" [An Education Project for Hokkaido Former Natives], Tōkyō jinruigakkai zasshi, 21:245 (1906), 432-433.

${ }^{244}$ Koganei Yoshikiyo, Jinruigaku kenkyū [Anthropological Research] (Tokyo: Ōokayama shoten, 1928), 511, 513. http://dl.ndl.go.jp/info:ndljp/pid/1018027/99.

${ }^{245}$ Alcohol addiction afflicted Ainu communities much the same as Native American ones that had been wounded by the trauma of pronounced social dislocation resulting from sustained periods of forced relocation, violence, and assaults on their cultural dignity.

${ }^{246}$ See Elizabeth D. Ludley, Reforming Japan: The Woman's Christian Temperance Union in Meiji Japan (Honolulu: University of Hawai'i Press, 2010).
} 
founded an Ainu school in Horobetsu where he preached to his students in their own language. Batchelor's initial efforts to minister to the Ainu were met with fierce resistance by local authorities who prosecuted him for violating foreign residence lawsuntil 1899 foreigners in Hokkaido had to reside in official exclusion zones in cities like Hakodate. The prosecutor commented that it was Batchelor's endeavor to promote the use of the Ainu language in his schools that drew the ire of the government, as he charged: "Mr. Batchelor is trying to make the Ainu language live while we desire it to die out. ${ }^{\not 247}$ Batchelor's involvement in the Temperance Movement also angered Japanese merchants who made a living selling sake to the Ainu. By the turn of the century, Batchelor had founded close to a dozen schools and influenced several generations of Ainu activists. ${ }^{248}$ Decades later, for his work as an Ainu scholar and humanitarian he was awarded the Order of the Sacred Treasure by the Emperor Meiji, and often took to entertaining foreign researchers, visiting dignitaries, and even members of the imperial family, instructing them on Ainu beliefs and customs while they toured Hokkaido's Ainu villages. ${ }^{249}$

Today, Batchelor is known more for his scholarly work on Ainu language, customs, culture, and spirituality than for his schools or activism. His study of the Ainu placed him within a certain fraternity of researchers who believed it their mission to travel the distant corners of the earth to document and preserve the cultural remnants of humanity's 'vanishing races' before they disappeared without a trace. Western anthropologists developed a keen fascination with the Ainu, whom they considered distant Caucasian

${ }^{247}$ John Batchelor, "Steps by the Way" (unpublished manuscript), 120, as cited in Siddle, Race, 69.

${ }^{248}$ Siddle, Race, 90.

${ }^{249}$ Ibid., 124. 
cousins, and Ainu cultural artifacts were appropriated and displayed for public consumption in Japan, Europe, and the United States. Ainu bodies, too, were displayed in what Medak-Saltzman has called the "stages of empire,",250 colonial exhibitions in Tokyo, Osaka, St. Louis, and London that allowed onlookers to simultaneously marvel at and mock their 'primitiveness.' Batchelor, himself, was personally involved in these projects $^{251}$ and was a firm believer in the ideas of scientific racism and Social Darwinism. As such, he viewed the Ainu, though not contemptibly but rather pitiably, as a race “inexorably" bound for extinction. ${ }^{252}$ Like Richard H. Pratt, the founder of the first 'Indian school' in Carlisle, Pennsylvania in 1879, who exhorted liberal reformers in the United States to "kill the Indian, save the man," 253 Batchelor, too, called upon the Ainu to assimilate to Japanese society or perish.

The international attention paid to the Ainu accented the visibility of their plight, and this became especially disconcerting to Japanese policymakers and scholars who were preoccupied with their nation's position in the geopolitical order. Iwaya Eitarō was a leading figure in Hokkaido education circles who published numerous articles and sat on a committee created by the Hokkaidō Kyoikukai (Hokkaido Education Society) to

\footnotetext{
${ }^{250}$ Danika Medak-Saltzman, "Staging Empire: The Display and Erasure of Indigenous Peoples in Japanese and American Nation Building Projects 1860-1904," (PhD diss., University of California, Berkeley, 2008).

${ }^{251}$ Frederick Starr was tasked with finding Ainu subjects to participate in the living anthropological exhibit at the 1904 St. Louis Fair. He attributed his success to Batchelor who was able to persuade nine Ainu from communities he was involved in to participate. See Frederick Starr, The Ainu Group at the Saint Louis Exposition (Chicago: The Open Court Publishing Company, 1904) https://archive.org/details/ainugroupatsaint00staruoft/page/n5.

${ }^{252}$ The following speaks volumes: "But nothing now can avert their doom. They must soon be quite of the past. And they will depart without having left any history or having made any perceptible mark in the world. One feels sorry for them, but the laws of nature are inexorable and must take their course." John Batchelor, Ainu Life and Lore: Echoes of a Departing Race (Tokyo: Kyōbunkan, 1927), 5.

${ }^{253}$ Taken from Richard H. Pratt's infamous address at George Mason University in 1892. See Richard H. Pratt, "The Advantages of Mingling Indians with Whites," in Americanizing the American Indians:

Writings by the 'Friends of the Indian' 1800-1900 (Cambridge: Harvard University Press, 1973), 260-271.
} 
brainstorm policy solutions for the lack of Ainu schooling. Unlike other committee members, Iwaya's support for Ainu education was not rooted in sentimentality for the cause of Ainu welfare. On the contrary, he blamed them for their own poverty and misfortune describing them as a people of such low character that "one can declare that they qualify ultimately as a people who would ruin a country." ${ }^{254}$ For Iwaya, the problem with Ainu education was that the Meiji government had let it fall into the hands of foreign missionaries, and this had left a "stain on the dignity of the Empire of Japan." ${ }^{, 25}$ So, Ainu welfare was not merely a pet project to soothe the guilty consciences of liberal reformers, but also became a potent nationalist cause as well.

The movement for Ainu welfare was based on a belief in the fundamental necessity of Ainu assimilation to modern Japanese society. The assimilation programs that welfare activists promoted sought to bind Ainu individuals to the land as small-scale independent farmers and called for the development of a comprehensive education system for Ainu youth. The Dawes Severalty Act of 1887 and the 'Indian residential schools' of the United States were especially of interest to such advocates. For example, in 1894 the Sapporo Historical Society sponsored a lecture by a visiting American official about how the Dawes Act seized community-held tribal lands transforming them into privatelyowned agricultural plots in an effort to encourage Native Americans on reservations to free themselves from government dependence and become propertied citizens. ${ }^{256}$ The

\footnotetext{
${ }^{254}$ Iwaya Eitarō, "Ainu no genshō” [The Ainu's Decline], Hokkaidō kyōikukai zasshi 6 (1891), 18.

${ }^{255}$ Iwaya Eitarō, "Ainu kyōiku no hitsuyō" [The Necessity of Ainu Education] Hokkaidō kyōikukai zasshi 18 (1894), 9.

${ }^{256}$ The sponsor of the bill, Sen. Henry Dawes, conceived of it as a humanitarian measure that would help Native Americans escape poverty and abuse encountered in the reservation system by assimilating them to mainstream American culture through private property ownership. Today, historians view the Dawes Act as a means of breaking up tribal land and selling it primarily to white farmers to encourage Western settlement. The Act did, indeed, amount to a massive land grab by white farmers. See Claudia B. Haake,
} 
lecture was translated by Nitobe Inazō, a leading Christian scholar, and circulated among members of the Temperance Movement and Ainu welfare reform circles. ${ }^{257}$ Similarly, we can see the influence of Native American residential schools on the question of Ainu educational reform in a lecture given by Tsuboi in which he asked the audience to compare two pictures: the first one showing a group of Native American children before entering a residential school, and the second "after four months of education and a decent life." He implored the audience to consider the difference and "see how much their features changed. ${ }^{, 258}$ We can also look to the curious career of Oyabe Zenichiro, a Japanese citizen who graduated from General Armstrong's Indian School in Virginia before conducting undergraduate work at Howard University and earning a Ph.D. from Yale University. After his time at Yale, Oyabe was invited to examine a school for indigenous Hawaiians in Honolulu. He was so moved by this experience that he requested that Japanese diplomats in Hawai'i submit a petition to members of the Diet on his behalf. ${ }^{259}$ Oyabe returned to Japan, moved to Hokkaido to open a school for Ainu

\footnotetext{
The State, Removal and Indigenous Peoples in the United States and Mexico (New York: Routledge, 2007), Emily Greenwalk, Reconfiguring the Reservation: The Nez Perces, Jicarilla Apaches, and the Dawes Act (Albuquerque: University of New Mexico Press, 2002), Patricia Nelson Limerick, The Legacy of Conquest: The Unbroken Past of the American West (New York: W.W. Norton \& Company, Inc., 1987), Janet A. McDonnell, The Dispossession of the American Indians, 1887-1934 (Bloomington: Indiana University Press, 1991).

${ }^{257}$ Siddle, Race, 69. For more details see Tomita Torao, "Hokkaidō kyūdojin hogo hō to Dōzu hō: Hikakushiteki kenkyū no kokoromi" [The Hokkaido Former Natives Protection Act and the Dawes Act: Attempting a Comparative Historical Study], Jinbungakkai kiyō 45 (1989).

${ }^{258}$ These comments were taken from a lecture entitled "Hokkaidō kyūdojin kyūiki jigyō" [An Education Project for Hokkaido Former Natives] given by Tsuboi in 1906. See Oguma Eiji, A Genealogy of Japanese Self-Images, trans. David Askew (Melbourne: Trans Pacific Press, 2002), 60. Tsuboi published an article the same year in the Tökyō jinruigakkai zasshi with the same title. It covers the same material as the lecture, but there is no commentary about Native Americans. The article: Tsuboi Shōgorō, "Hokkaidō kyūdojin kyūiki jigyō" [An Education Project for Hokkaido Former Natives], Tōkyō jinruigakkai zasshi, 21:245 (1906).

${ }^{259}$ A diplomat's record of Oyabe's petition can be found in Takakura, Ainu seisakushi, 608-609. http://dl.ndl.go.jp/info:ndljp/pid/1270068.
} 
youth in Abuta, ${ }^{260}$ and formed the Hokkaidō Kȳ̄dojin Kyōikukai (Hokkaido Former Natives Education Society). His petition, which highlighted his unique experiences in the assimilationist indigenous education system of the United States, lent considerable weight to the welfare advocates' position while the Diet deliberated on the merits of a comprehensive 'protection' law.

The first draft of an Ainu 'protection' bill was proposed by Katō Masanosuke at the fifth Imperial Diet in 1893. Like Oyabe, Katō was influenced by his time spent in the United States learning about Native Americans. While touring New England he was told the story of how many of the area's past Native American tribes had been killed off through a combination of epidemic disease and genocidal violence. Katō was convinced that the Meiji government had to take drastic action to prevent the same thing from happening to the Ainu. ${ }^{261} \mathrm{He}$ defended the bill by couching it in the language of national honor, arguing that if it were rejected the Diet will have "given voice to the criticism of the people of each European country by saying [we] oppress the weak, and scorn and bully people because of their racial differences. ${ }^{, 262}$ His Diet colleagues, unmoved, gave voice to this hypothetical criticism twice, rejecting Katō's initial draft and a second two years later. During the hearings for the third draft, Diet member and former Hokkaidō government official and educator, Shirani Takeshi, played a pivotal role in getting the legislation passed. Shirani's own position was that while Ainu were destined to die out, "it is against human nature not to extend a helping hand," though he cautioned that

\footnotetext{
${ }^{260}$ Yoshinobu Kotani, "Ainu Collections in North America: Documentation Projects and the Frederick Starr Collections," in Ainu: Spirit, 139.

${ }^{261}$ Siddle, Race, 70.

${ }^{262}$ Cited in Oguma, Boundaries, 37.
} 
despite this "we must definitely not undertake the preservation of the [Ainu] race."263 Arguments such as this carried the day and the third draft was accepted.

The Hokkaidō kyūdojin hogo hō (Hokkaido Former Natives Protection Act), the fruit of many years of Ainu welfare advocacy, was passed in 1899 and stipulated that each Ainu household was to be granted five chō (approximately twelve acres) of tax-exempted land that could not be sold or transferred "except by inheritance." The government also retained the right to seize these plots if they were not successfully cultivated within 15 years, and placed Ainu community assets under government control. ${ }^{264}$ In essence, the land promised to the Ainu was simply a grant, one that did not entail full rights of ownership. With the passing of the Protection Act the Meiji government also pledged to undertake the construction of elementary schools to serve the needs of all Ainu children in Hokkaido. The Kyūdojin jido kyōiku kitei (Regulations for the Education of Former Native Children) that passed two years later inaugurated a basic four-year curriculum for Ainu students. For Japanese students, Meiji leaders had crafted an extensive public school system three decades prior under which students studied a multitude of subjects deemed essential to national success, including history, geography, mathematics, and science. ${ }^{265}$ Under the new education regulations, Ainu children were segregated from their Japanese peers and "prevented from learning history, geography and science due to

\footnotetext{
${ }^{263}$ Cited in Ogawa Masahito, "The Hokkaido Former Aborigines Protection Act and Assimilatory Education," Indigenous Minorities and Education: Australian and Japanese Perspectives on their Indigenous Peoples, the Ainu, Aborigines, and Torres Strait Islanders, ed. Noel Loos and Osanai Takeshi (Tokyo: Sanyūsha, 1993), 239.

264 "Hokkaido Former Natives Protection Law," [March 1, 1899], trans. Richard Siddle, in Reading Colonial Japan: Text, Context, and Critique, ed. Michele M. Mason and Helen J.S. Lee (Stanford: Stanford University Press, 2012), 57-59.

${ }^{265}$ Brian Platt, "Japanese Childhood, Modern Childhood: The Nation-State, the School, and $19^{\text {th }}$-Century Globalization,” Journal of Social History 38:4 (2005), 973-974.
} 
their emotional and intellectual immaturity." ${ }^{, 266}$ Instead their education focused on training in Japanese cultural norms, Japanese language classes, and practical subjects like farming and domestic tasks. Japanese and Ainu schools shared one major point in common: They functioned as social engineering laboratories where students were inculcated with a sense of shared heritage and national identity, often through the symbolism of the 'divine' emperor. ${ }^{267}$

Ainu children were taught that they were kyüdojin (former natives) that had to be molded into common subjects of the Japanese empire. Like their counterparts in North American residential schools, Ainu students could be punished severely for speaking in their own language. During this period, Japanese children could also be treated harshly if they continued to speak in their regional dialects, an act that could trigger the wrath of their teachers who regularly employed beatings and ridicule in response. ${ }^{268}$ However, despite any apparent similarities here, Japanese students were, well, 'Japanese' after all. For Ainu students the stigma of their 'racial' identity made them regular targets for harassment and intimidation regardless of their behavior and aptitude. Japanese students and teachers regularly derided them for being 'hairy' and 'unhygienic,' and made harsh, racist taunts about them 'being descended from dogs. ${ }^{269}$ The trauma induced by these

\footnotetext{
${ }^{266}$ In regions with higher numbers of Ainu children local schools were erected solely for their use, though in less populated areas Ainu students were made to attend the same schools as local Japanese children but were kept segregated from them. Nazumi Takeda and James Williams, "Plurality, Identity, and the State: National Education Policy Towards Indigenous Minorities in Japan and Canada," Comparative Education 44:1 (February, 2008), 79. For a more thorough analysis of Ainu education, including public, private, and religious schools, see Christopher J. Frey, "Ainu Schools and Education Policy in Nineteenth-Century Hokkaido, Japan," (PhD Diss., Indiana University, 2007).

${ }^{267}$ Benjamin Duke, The History of Modern Japanese Education: Constructing the National School System, 1872-1890 (New Brunswick: Rutgers University Press, 2009), 61-76.

${ }^{268}$ Instances of this were common in the Meiji period, as kokugo (the national language, based off of the speech of well-to-do Tokyoites) had only recently been standardized.

${ }^{269}$ See Ogawa Masahito, Kindai Ainu kyoiku seidoshi kenkyu [Study of the Modern Ainu Educational System] (Sapporo: Hokkaido Daigaku Tosho Kankyokai, 1997), and Emori Susumu, Ainu no rekishi. This
} 
schools had compounding negative effects on Ainu communities across generations, driving many former students to deliberately try to dilute the 'black stock' (kurosuji) in their Ainu bloodline by exclusively seeking out Japanese marital partners. ${ }^{270}$

Furthermore, many Ainu often chose to move to cities in Hokkaido and elsewhere in an attempt to escape harassment and discrimination— to 'pass as Japanese. ${ }^{271}$

This strategy was problematic, however, in that the enforcement terms of the Protection Act dictated that only Ainu who had at least one 'pure-Ainu' grandparent, were primarily engaged in agriculture, and maintained residence in their home villages were eligible for benefits. Simply leaving home to escape discrimination and poverty meant, in a legal sense, that one ceased to be Ainu. It also meant that any land allotted by the Protection Act would then be forfeit, and although most Ainu families had received some land, in reality it was far below the amount promised. Because they could not sell the allotments the government had granted them, many Ainu had little choice but to rent their land to Japanese neighbors in long-term agreements far below market value, often to settle debts incurred as a result of their impoverishment. A survey conducted in 1923 showed that in spite of the fact that $50 \%$ of Ainu families were listed as farmers, only $19 \%$ of land allotted by the Protection Act remained in Ainu hands. ${ }^{272}$ As should be made

appears to have been a play on words between 'Ainu' and 'inu' (Japanese for 'dog'). Also, there is a myth in Ainu culture that describes their origins as having stemmed from the mating of a dog and a human, though some scholars believe that this was actually a story created to disparage the Ainu during the period of Matsumae rule.

${ }^{270}$ Belief in Hypodescent by means of the 'one drop rule' remains common in Japan; thus, individuals with Ainu or minority blood are often socially assigned to that minority status due to the presence of "black stock' in their bloodline. Lewallen, "Clamoring Blood," 51.

${ }^{271}$ Mark Watson has taken issue with academic treatment of the Ainu focusing solely on Hokkaido and has called on scholars to examine the lives of Ainu diasporas throughout Japan. See Mark K. Watson, Japan's Ainu Minority in Tokyo: Diasporic Indigeneity and Urban Politics (New York: Routledge, 2014).

${ }^{272}$ Siddle, Race, 71. 
clear, Japanese liberal welfare reformers genuinely believed they were acting in Ainu interests, but rarely did they suspend their paternalistic inclinations long enough to consider the wishes of the Ainu people they claimed to help. In reality, they were agents of imperialism, the assimilation they preached little more than a means of directing the Ainu to "assume their natural and proper place in a racially defined hierarchy of dependent states within the empire. ${ }^{273}$

\section{Ainu Activism and Ethnotourism}

By the turn of the twentieth century, Ainu oppression had become inveterate and unrelenting. The Protection Act and the introduction of state-run assimilationist schools brought Ainu people firmly under the gaze of Japanese colonial authorities. An interesting dichotomy had developed, however. While the Meiji government attempted to annihilate Ainu culture, traditions, and identities and mold the Ainu people into complacent Japanese subjects, some government officials and entrepreneurs, eager to profit from tourism to Japan's wild northern frontier, found an attractive commodity in showcasing the 'primitiveness' of the 'hairy' Ainu to Japanese travelers. This development was facilitated by a newly constructed network of roads and railways that allowed Japanese tourists to travel throughout the nation. Hokkaido, with its natural abundance of rivers, lakes, wildlife, mountains, and hot springs, became a highly desirable destination, and after three decades of racialist discourse Japanese perceptions

\footnotetext{
273 This same logic applies to other colonized peoples whom the Japanese government subjected to assimilation policies, including Ryūkyūans, Taiwanese Aborigines, and later Koreans. Michael Weiner, "Discourse of Race, Nation and Empire in pre-1945 Japan," Ethnic and Racial Studies 18:3 (1995), 452.
} 
of the Ainu had undergone radical change - they were transformed into a living relic, a people firmly of the past and only ephemerally of the present.

The first Ainu ethnotourist sites predated the Protection Act, stretching back to the early forced relocation period in the 1880 s, and many of the popular tourist sites today, such as Shiraoi and Chikabumi (Asahikawa), were former reservation sites. Prior to this, in the early nineteenth century, Ainu woodcarvings of typical everyday items (chopstick cases, tobacco pipes, etc.) decorated with Ainu motifs had become popular within Ezo's Wajin communities. ${ }^{274}$ The social dissolution and poverty stemming from Meiji-era assimilation projects caused many new Ainu farmers to have to supplement earnings through the sale of carvings and textiles, and they found plenty of eager buyers among Japanese locals and travelers alike. In 1878, Isabella Bird, an English travel writer, commented during her excursion to Hokkaido that "the lower class of Japanese are constantly to be seen wearing the product of Ainu industry." ${ }^{275}$ This selling of crafts mentioned here by Bird later expanded into the creation of tourist "villages" where visitors could witness Ainu people perform songs, dances, and rituals like iyomante ${ }^{276}$ as a form of leisure entertainment.

The rise of Ainu ethnotourism was also a unique product of Japan's modernization. The Meiji state had employed a vast array of "imperial pageantry" as a means of legitimizing its power in regions outside of the capital, the most dramatic among these being the progress, "a style of ritual in which the emperor traveled around

\footnotetext{
${ }^{274}$ Chisato O. Dubreuil, “Ainu Journey: From Tourist Art to Fine Arts,” in Ainu: Spirit, 335-336.

${ }^{275}$ Isabella Lucy Bird, Unbeaten Tracks in Japan: An Account of Travels on Horseback in the Interior, vol. 2 (New York: G. P. Putnam's Sons, 1881), 67.

${ }^{276}$ Iyomante, commonly known as the 'bear ceremony,' is the most well-known Ainu ritual, often attracting thousands. It encompasses the 'sending back' of a bear's spirit through ritual sacrifice.
} 
the countryside watching and being watched by the people who were becoming Japanese."277 In this capacity, the emperor Meiji toured Hokkaido in 1881 and paid a visit to the Ainu village of Shiraoi bringing national attention to burgeoning Ainu tourism sites. Promotion was further facilitated by the rise of photographic postcards ${ }^{278}$ featuring individual portraits of Ainu subjects that exoticized their racialized features and 'primitive' lifeways in a manner reminiscent of Edward S. Curtis' highly choreographed depictions of Native Americans in the wildly popular The North American Indian ${ }^{279}$ photobook series. This connection was not mere happenstance. Indeed, the rise of Ainu ethnotourism in the late nineteenth century fits within the pattern of indigenous ethnotourism globally. The tours were employed by settler colonial states as a way to contrast the primitive with the modern, to demonstrate the triumph of nations and empires and their mastery over nature, superstition, and the past—attributes personified by native 'Others.' Lorenzo Veracini writes that "settlers generally prefer to operate in environments where 'evidence' of a capacity to advance environmental transformation allows them to think about their collective endeavor as being endowed with an inherent strength. ${ }^{280}$ Indigenous ethnotourism provided such spaces. Organizers wielded the power to render their indigenous subjects ahistorical, to take them out of the realm of

\footnotetext{
${ }^{277}$ Takashi Fujitani, "Inventing, Forgetting, Remembering: Toward a Historical Ethnography of the NationState," in Cultural Nationalism in East Asia: Representation and Identity, ed. Harumi Befu (Berkeley: Institute of East Asian Studies, University of California, 1993), 92.

${ }^{278}$ The Japanese national postal system originated in 1871, and because materials that promoted racialized images of the Ainu were disseminated through it we should consider it part of the colonial infrastructure of Hokkaido. See Sidney C.H. Cheung, "Men, Women and 'Japanese' as Outsiders: A Case Study of Postcards with Ainu Images," Visual Anthropology 13:3 (2000), 235-248.

${ }^{279}$ Curtis is known to have staged the photograph sessions, taking Native Americans who ordinarily fashioned themselves in Western clothes and lived in modern housing and dressing them in 'native' clothing in 'traditional' settings.

${ }^{280}$ Lorenzo Veracini, "Understanding Colonialism and Settler Colonialism as Distinct Formations," Interventions 16:5 (2014), 624.
} 
human history and naturalize them as part of the landscape of the frontier while presenting their own societies as apotheoses of progress.

Although indigenous tourist "villages" were designed as artificial, essentialist representations of 'primitive' societies, they could also be spaces of resistance and renewal evincing the complexities of modern indigenous life. We can see evidence of this in the example of the Ainu group at the 1904 St. Louis Exposition. Frederick Starr, the American anthropologist sent to acquire Ainu subjects for the event, made sure to select only those individuals whose physical traits aligned with the Ainu's ascribed racial characteristics—hirsute, tall, broad bodies with Caucasoid facial features. ${ }^{281}$ Japanese assimilation laws, of course, prohibited Ainu from donning traditional clothing and jewelry, beards, long hair, or tattoos, and in photos taken of the group before they embarked for the United States the men all have short hair and clean-shaven faces, though by the time they reached St. Louis they had not shaved or groomed and resembled the Ainu archetype visitors had anticipated. ${ }^{282}$ It is fair to point out that the question of whether this was a form of active resistance is a matter of conjecture; we do not have their version of these events after all, only the musings of Starr and the fair organizers. Regardless, we must account for the way this exposition provided a space for these men to live out aspects of a prohibited culture. Another interesting detail about the fair is that the organizers felt the need to institute new rules to prevent the 'contamination' of

\footnotetext{
${ }^{281}$ See Starr, Ainu Group and Nancy J. Parezo and Don D. Fowler, Anthropology Goes to the Fair: The 1904 Louisiana Purchase Exposition (Lincoln: University of Nebraska Press, 2007).

${ }^{282}$ Danika Medak-Saltzman, "Transnational Indigenous Exchange: Rethinking Global Interactions of Indigenous Peoples at the 1904 St. Louis Exposition," American Quarterly 62:3 (September 2010), 602604.
} 
indigenous living quarters, ${ }^{283}$ as the groups housed there regularly traded tools, ornaments, and crafts with each other, carried them back to their living spaces, and made use of them in inventive ways - a process demonstrating that, indeed, "tourism is creative of culture, ${ }^{, 284}$ even when those who control its modes of exposition attempt to present it in reified form.

In 1903, at the Osaka Industrial Exposition, Japan staged its own 'living human exhibit' led by anthropologist Tsuboi Shōgorō (discussed earlier) and comprised of five Ainu, four Taiwanese Aborigines, and two Ryūkyūans. ${ }^{285}$ One of the Ainu participants, Fushine Kōzō, was part of a growing circle of activists in Hokkaido who looked to Christianity and the Temperance Movement for inspiration and felt betrayed by the failures of the Protection Act. Fushine had agreed to participate in the Osaka Exposition in order to raise funds for an independent school he had founded, ${ }^{286}$ and his example here is important in that it connects the development of Ainu ethnotourism to the rise of Ainu activism during this same period, two forces that have existed in dynamic tension ever since.

Ainu activism in the early twentieth century consisted of two coetaneous movements, both with close connections to Rev. John Batchelor. Interestingly, both groups were supporters of assimilation believing it was the only way to alleviate the

\footnotetext{
${ }^{283}$ Ibid. The various indigenous groups lived on set, in the very houses in which they were exhibited.

${ }^{284}$ Bob Simpson, "Tourism and Tradition from Healing to Heritage," Annals of Tourism Research 20:1 (1993), 171.

${ }^{285}$ Tsuboi's original plan included the use of Korean and Chinese subjects, but this idea was abandoned following public outcry in Taiwan and Korea. Tessa Morris-Suzuki, "Tourists, Anthropologists, and Visions of Indigenous Society in Japan," in Beyond Ainu Studies: Changing Academic and Public Perspectives, ed., Mark J. Hudson, ann-elise lewallen, and Mark K. Watson (Honolulu: University of Hawai'i Press, 2014), 52.

${ }^{286}$ Siddle, Race, 125.
} 
suffering of Ainu communities; however, they also remained fiercely opposed to the discrimination that lay at the heart of extant government-run assimilation programs. The first group was comprised primarily of young Ainu who were educated in or associated with Batchelor's religious schools and ministries. The first such activist, Tarō Kannari, hailed from one of the few elite Ainu families of the early Meiji period and became the head instructor at Batchelor's first school in 1885. Kannari was an early supporter of an Ainu welfare bill but was unable to secure the support of tradition-minded Ainu elders. Consumed by guilt and alcoholism he was fired from Batchelor's school in 1888 and drank himself to an early death at the age of thirty. ${ }^{287}$ Kannari's approach of trying to bring together sympathetic government officials and Ainu elders to create and enact welfare programs centered on the cultural assimilation of Ainu youth was slightly ahead of its time.

A few decades later, as Batchelor's circle of religiously inspired Ainu youth grew, they established several small magazines to advocate for the end of segregated education and to feature poetry and essays by young Ainu authors. Takekuma Tokusaburō composed Ainu Monogatari (The Tale of the Ainu) in 1918, the first book about the Ainu composed by one of their own. Takekuma challenged the depiction of his people as a 'dying race,' arguing: “Even if appearance and customs gradually lose their previous form, the quantity of Ainu blood will not decrease...the Ainu race in the future will not die out but should assimilate to the Yamato race. ${ }^{288}$ Chiri Yukie, a promising young Ainu poet, compiled and recorded Ainu oral literature into Ainu shinyōsh $\bar{u}$ (Collection of

\footnotetext{
${ }^{287}$ Ibid., 115

${ }^{288}$ Takekuma Tokusaburō, Ainu Monogatari [A Tale of the Ainu] (Tokyo: Hakubunkan, 1918), 15. http://dl.ndl.go.jp/info:ndljp/pid/958345.
} 
Ainu Epics of the Gods), published in 1923 just after she passed away at the tender age of nineteen. Her work allowed young Ainu to find pride in Ainu culture even as it was under assault by government officials. Another member of the group, Iboshi Hokuto, became a published poet, though he, too, died young at the age of twenty-seven. Through his poetry and activism he became one of few voices at the time questioning the logic of assimilation, advocating instead for the Ainu to "kick aside the social feelings of irrational prejudice and manifest our purity as a race." 289

It is important to note that during this time Japanese imperial policy in Taiwan and Korea had given rise to debates between assimilationists who promoted yuggo, the 'fusion of blood' through intermarriage between Japanese and other racial groups, and eugenicists who argued that such policies would degrade the quality of the Yamato race. This policy debate was applied to the Ainu as well. In 1918, Hiraoka Sadatarō, the Governor of Karafuto (present-day Sakhalin), published an essay in which he investigated the question of whether introducing Ainu blood into the Japanese race "will violate the movement to preserve our national essence. ${ }^{290} \mathrm{He}$ argued that although the Ainu should be 'civilized' through education and agriculturalization, intermarriage and adoption between the races should be suppressed by the state. When Iboshi spoke of the Ainu's need to work toward the "purity" of their "race," he was imagining a new Ainu identity, coopting eugenicist dialogue as a form of anti-colonial resistance.

\footnotetext{
${ }^{289}$ Iboshi Hokuto, Kotan: Iboshi Hokuto Ikō [Kotan: The Posthumous Works of Iboshi Hokuto] (Tokyo: Sōfuukan, 1984), 116. He uses the word "minzoku" which at the time was becoming synonymous with jinshu, the word then used to describe 'race' in scientific literature. Minzoku can be translated as 'race,' 'ethnic group,' 'people,' or 'nation.' Today, in Japan the common way to refer to the Ainu is with 'Ainu minzoku;' this does not convey a racialist meaning but is rather translated as 'the Ainu people.'

${ }^{290}$ Hiraoka Sadatarō, "Ainu jinshu shobun ron" [On the Management of the Ainu Race], in Aoyama Tōen, Kyokuhoku no bettenchi (Tokyo: Hōbunsha, 1918), appendix 6. http://dl.ndl.go.jp/info:ndljp/pid/959144
} 
The second major group of activists was composed primarily of Ainu elders and members of the Ainu elite, figures who had become successful farmers and small businessmen. Through their network of connections, they were able to acquire the support of sympathetic government officials, as well as that of John Batchelor. Their initial agenda was to form an organization that would represent the interests of all of the Ainu in Hokkaido, and in 1930 they founded the Hokkaidō Ainu Kyōkai (Ainu Association of Hokkaido) with Kita Shōmei, a Japanese official from the Hokkaido prefectural government, as its chairman along with Fushine Kōzō-the Ainu elder from the Osaka Exposition—as one of the Vice-chairmen. ${ }^{291}$ From its inception, many poor Ainu were skeptical of the AAH considering it either an organization catering to the interests of the Ainu elite, or a mere appendage of the prefectural government. AAH's close political connections, however, allowed them to effectively advocate Ainu interests as the organization developed into the principal venue through which changes to Ainu policy continue to be effected. Their first major success was the revision of the Protection Act. They petitioned the government to abolish educational segregation, to ease restrictions on selling allotted land, and for welfare funds to be made available to Ainu engaged in occupations other than agriculture believing these issues were contributing to the rise of anti-Ainu discrimination and thwarting assimilation efforts. ${ }^{292}$ On March 12, 1937, all of the revisions they proposed were accepted by the Diet.

The AAH also voiced its concern over the effects of tourism on the Ainu's public image, as many members felt it was perpetuating the very stereotypes they were trying to

\footnotetext{
${ }^{291}$ Howell, "Making 'Useful Citizens' of Ainu Subjects in Early Twentieth-Century Japan,” The Journal of Asian Studies 63:1 (2004), 13-14; Siddle, Race, 134.

${ }^{292}$ Siddle, Race, 143-145.
} 
dispel. At a government-sponsored discussion regarding revisions to the Protection Law a group of AAH members met with officials and prominent scholars to air their concerns about the popularity of Ainu ethnotourism, arguing that it was a threat to the assimilation project. All of the participants, for example, favored an outright ban on the iyomante (bear ceremony) and Ainu dances. ${ }^{293}$ One member complained that children were forced from school to participate in Ainu cultural performances whenever dignitaries paid a visit. In fact, at the time, Ainu schools were part of a standard village tour. Visitors would meet the students and bear witness to their transformation, contrasting the traditional look and customs of Ainu performers with that of the modern village youth. ${ }^{294}$ Another participant argued that tourist activities damaged Ainu people's self-esteem and depicted an inaccurate version of Ainu life in order to profit from visitors' curiosity. Takakura Shinichiro, a Japanese historian and economist at Hokkaido Imperial University, suggested that the government build an official museum in Sapporo to satisfy the desires of tourists while preventing them from disturbing Ainu communities. ${ }^{295}$ Ultimately, Ainu ethnotourism had played a role in the growth of Hokkaido's overall tourism sector and government officials took no action to reign it in.

While activists levied complaints against Ainu ethnotourism, the industry itself was experiencing significant growth. Morris-Suzuki explains that in the 1930s "Japan was beginning to develop a conscious tourism policy," not only in a commercial sense, but "as

\footnotetext{
293 Howell, "Making," 16-17.

${ }^{294}$ Morris-Suzuki, "Tourists," 53.

${ }^{295}$ His commentary went unheeded at the time, but the Japanese government is now sponsoring the construction of the new Upopoy Ainu Musuem and Park in Shiraoi. The original museum was built there in 1965 on a section of uninhabited land to keep visitors away from Ainu in the local community.
} 
a way of presenting 'Japan' both to its own citizens and to the outside world." ${ }^{296}$ A similar trend was occurring throughout Imperial Japan, with Japanese tourists sojourning to Korea, Taiwan, and Manchuria to take in the sites of famous military victories and other symbolic representations of empire. ${ }^{297}$ In the Japanese collective imagination, Hokkaido occupied a tourism space straddling mainland Japan and its more distant colonies. Most tourists visited larger, more established sites at Shiraoi and Chikabumi, and Ainu-made products from these regions - woodcarvings of bears, attushi dolls, and various embroidered goods dressed with Ainu motifs_-increased in popularity and could even be found in department stores in Tokyo and Osaka. ${ }^{298}$ Newspapers, magazines, novels, and later film offered consumers an array of rich, though problematic and romanticized storytelling about Ainu characters. ${ }^{299}$

For Ainu participants, tourism offered not only financial rewards but also a space to reclaim their indigenous identities, to perform and engage with a culture that had been savaged by colonial oppression. Given the realities of life under coercive assimilation, museums and tourist spaces became the primary means through which rituals, songs, dances, and craft techniques could be performed and transmitted. Yet, this process was occurring in a commercial milieu and the interests of consumers exerted a substantial influence on Ainu cultural practice and production. Alexis Celeste Bunten, a researcher of

\footnotetext{
${ }^{296}$ Morris-Suzuki, “Tourists," 53.

${ }^{297}$ Kenneth J. Ruoff, Imperial Japan at its Zenith: The Wartime Celebration of the Empire's 2,600 Anniversary (Ithaca: Cornell University Press, 2010).

${ }^{298}$ Lisa Hiwasaki, "Ethnic Tourism in Hokkaido and the Shaping of Ainu Identity," Pacific Affairs 73:3 (2000), 399.

${ }^{299}$ Siddle, Race, 100-101 provides the following examples: The popular magazine Chūō Kōron ran a story called ‘Ainu no ko' [Ainu Child] (1914), Bunmei magazine's 'Hotchare gyozoku' [The Dog Salmon] (1935); the prize-winning novel Koshamain ki [The Tale of Koshamain](1936); the novel Ainu no gakkō [The Ainu School] (1942); the film Kotan no kuchibue [Whistle of Kotan] (1959).
} 
Maori and Native American ethnotourism, speaks to this dilemma: "Commoditizing a living culture gives birth to an acute paradox...Indigenous tourism professionals feel enormous pressure to deliver a competitive product that appeals to perceived consumer desires for 'the Other' while confronting stereotypes that persist in popular culture."300 One of the most enduring and problematic of these stereotypes is the belief that Indigenous peoples have no history on account of their assumed 'primitiveness,' not just in the literal sense that they do not possess written histories, but that the people themselves exist outside of history. In other words, indigenous cultures are too often assessed through an essentialist, ahistorical critique that casts doubt on their authenticity.

An interesting dynamic here is that it is not simply outsiders that invoke the charge of inauthenticity, but often traditionalists within indigenous communities themselves who do so with the highest degree of conviction. This is one reason why many activists and elders in the Ainu community have argued that ethnotourism reinforces stereotypes of the Ainu as a 'primitive' people. Yet, we need only look to culture as a process, not a product in order to move beyond the charge of inauthenticity and understand ethnotourism as being more than the staging of 'primitiveness,' or of simply 'preserving' a past culture with little relevance or applicability to the present. The agency of those working in ethnotourism allows for the ongoing formation of new culture and new identities.

One example that demonstrates the occurrence of this phenomenon in Ainu ethnotourism is the production of wood-carved bear sculptures. This Ainu craft began in the 1920s and it violated longstanding Ainu religious taboos, as animals were considered

\footnotetext{
${ }^{300}$ Emphasis added. Alexis Celeste Bunten, "More like Ourselves: Indigenous Capitalism through Tourism," The American Indian Quarterly 34:3 (2010), 288.
} 
too sacred to reproduce in secular artwork. ${ }^{301}$ Interestingly, it was a descendent of the Tokugawa family — the owner of a large Hokkaido ranch — who first introduced local Ainu to wooden bears carved by Swiss farmers after a trip to Europe. ${ }^{302}$ Ainu woodcarvers responded to their poor economic conditions by altering their spiritual practices to meet their material needs, and they began to carve wood into the shape of bears and other sacred animals as a commercial product designed for tourists. These bear sculptures grew in popularity after a Chikabumi artist was commissioned to carve one for Emperor Hirohito in $1936,{ }^{303}$ and today they are perhaps the most recognizable souvenir sold at Ainu tourist sites. Another example is the creation of the Marimo matsuri (Marimo festival) that takes place annually at Lake Akan. Today, Akan is known as a vibrant Ainu tourism area, but the majority of Ainu families who settled in the region did not do so until 1953, after they petitioned the Maeda family_local timber magnates who owned much of the land - to allow them to establish a kotan there. ${ }^{304}$ The new ceremony had no direct precedent in Ainu history, rather it was created by the Akan Ainu to pray for the recovery of Lake Akan's marimo, a spherical moss unique to the region, which was found to be endangered. The Akan Ainu, themselves comprised of families from many different regions of Hokkaido, 'invented' the festival as a means of affirming bonds within the community and reestablishing balance with the nature of Lake Akan. ${ }^{305}$ Like all cultures, Ainu culture is not static; its authenticity lies in the meaning it takes on by

\footnotetext{
${ }^{301}$ William W. Fitzhugh, “Ainu Ethnicity,” in Ainu: Spirit, 25. Ainu men did carve animal figures into religious implements, such as inau (prayer sticks).

302 Ohtsuka Kazuyoshi, “Tourism, Assimilation, and Ainu Survival Today," in Ainu: Spirit, 93.

${ }^{303}$ Posthumously called Shōwa Tenno (Emperor Shōwa) in Japan. Japanese emperors take on their reign name after death.

${ }^{304}$ Sidney C.H. Cheung, "Rethinking Ainu Heritage: A Case of an Ainu Settlement in Hokkaido, Japan," International Journal of Heritage Studies 11:3 (2005), 202-205.

${ }^{305}$ Ibid., 207-208.
} 
those who practice it in the present, as well as those who have practiced it at different points in time, meaning that Ainu beliefs, material culture, and other forms of artistic expression must be historicized. In short, they must be understood as something flexible, adaptable, and subject to the processes of historical change.

In fact, we can look to early modern Ainu history to see similar examples of cultural synthesis and adaptability. Edo-period Ainu-e woodblock prints, for example, show evidence of pre-modern Ainu communities utilizing foreign materials acquired via trade — metal and glass ornaments, sake, silks, and Japanese swords (which they wore across their back, not at the side) — in the production of myriad cultural items, from objects used in daily life to those incorporated into important ritualistic ceremonies. ${ }^{306}$ Another example of dynamic cultural change can be found in the creation of the iyomante ceremony. We have no evidence of the iyomante ceremony's existence before the late eighteenth century. The public ritual during which many kotan along a river system would gather to carry out a bear sacrifice was a response to drastic social changes that accompanied the rise of commercial fisheries, possibly a means of reasserting communal ties as large numbers of Ainu left the kotan for prolonged periods. ${ }^{307}$ We can see here on account of the examples above that the contemporary charge of inauthenticity in Ainu tourism is a facile exercise in one-dimensional ahistoricism.

Perhaps the most significant reason why Ainu ethnotourism has long been a source of discord within Ainu communities is that it brings the inequities and humiliation

\footnotetext{
${ }^{306}$ See Sasaki Toshikazu, “Ainu-e: A Historical Review," in Ainu: Spirit and Sasaki Toshikazu, Ainu eshi no kenkyū [Research on the Artistic and Written Depictions of the Ainu] (Tokyo: Sōfūkan, 2004).

${ }^{307}$ Howell, Geographies, 118; Sasaki Toshikazu, "Iomante kō: Shamo ni yoru Ainu bunka rikai no kōsatsu" [A Study of Iomante: Considering Japanese Perspectives on Ainu Culture], Rekishigaku kenkyū 613 (1990).
} 
suffered under colonial rule into sharp relief. As a consequence of the racialized colonial context in which Ainu tourism arose, experiences that Ainu individuals encountered through it often left deep scars. An English-language travel guide issued by Japan's Government Railways, for instance, cautioned visitors that many Ainu were "ashamed to perform the old manners of their ancestors for money" and warned them to "refrain from laughing" or "assuming an attitude of mockery."308 One article by an Ainu author featured in local newspapers describes tourists who would walk up to private homes, "lean in windows, roll up blinds and point silently...like looking at animals in a zoo.",309 Another article implored visitors to "stop treating us like spectacles." 310 The author of the latter article, a local community leader in Shiraoi, asked tourists to show them respect and to consider the Ainu men from the area who had been conscripted to serve in Japan's imperial forces. Ainu men had served in the Japanese military since the Russo-Japanese War, some as conscripts and others as volunteers. Often, this was one strategy of escaping trauma and discrimination through a process Morris-Suzuki refers to as "equality through invisibility." ${ }^{311}$ To escape poverty, discrimination, and everyday indignities many more Ainu, perhaps the majority, decided to relocate to cities throughout the Japanese

\footnotetext{
${ }^{308}$ Kindaichi Kyosuke, Ainu Life and Legends (Tokyo: Board of Tourist Industry, Japanese Government Railways, 1941), 76-81.

${ }^{309}$ Hagiwara Mojiki, "Jūtaku no kaizen wa Utari kōjō no moto" [Improving Residences, Based on Ainu Statements] Ezo no hikari 3 (1931), reprinted in Ainu shi: Katsudōshin hen, ed. Hokkaidō Utari Kyōkai (Sapporo: Hokkaidō Utari Kyōkai, 1994), 37.

${ }^{310}$ Moritake Takeichi, "Misemono atsukai wo chūshi seyō" [Stop Treating Us Like Spectacles] Otaru Shimbun, August 24, 1934, reprinted in Ainu minzoku kindai no kiroku, ed. Ogawa Masahito and Yamada Shinichi (Tokyo: Sōfūkan, 1998), 399.

${ }^{311}$ Morris-Suzuki, "Tourists," 47.
} 
archipelago where they or their children could hope to one day pass as non-Ainu and live in anonymity. ${ }^{312}$

Relatively few Ainu actually sought to make a living in either tourist activities or the production of traditional handicrafts, as the ownership of these ventures had long been in the hands of Japanese owners, meaning that only a small share of the profits flowed into Ainu communities. ${ }^{313}$ Most Ainu, therefore, did not seek out encounters with tourists voluntarily or consentingly. Moreover, as tourist interest grew so too did renewed academic interest. Kodama Sakuzaemon of Hokkaido Imperial University (later renamed Hokkaido University), for example, amassed the largest ever collection of Ainu ancestral human remains — 1,004 skulls and other bones—between 1934 and $1956 .{ }^{314}$ Researchers also took advantage of this tourism infrastructure to conduct studies on Ainu subjects, usually posing as medical professionals claiming that the blood samples and bodily measurements they were taking would be used to cure diseases that impacted Ainu communities. Kayano Shigeru, the late Ainu activist and first Ainu Diet member, recounted the trauma of such experiences:

I despised scholars of Ainu culture from the bottom of my heart...each time they came to Nibutani, they left with folk utensils. They dug up our sacred tombs and carried away ancestral bones. Under the pretext of research, they took blood from villagers and, in order to examine how hairy we were, rolled up our sleeves, then lowered our collars to check our backs. My mother once staggered home after I don't know how

\footnotetext{
312 According to a 2013 Hokkaido Prefectural Government survey only 16,786 Hokkaido residents identified as "Ainu," whereas some experts believe the number of Ainu-descended people within the entire Japanese archipelago to be as high as 300,000. Nearly a quarter of the Hokkaido Ainu polled claimed to have been victims of serious discrimination with most instances occurring during interactions with government workers and at school. https://www.ainu-assn.or.jp/ainupeople/life.html.

313 Hiwasaki, "Ethnic," 401.

314 ann-elise lewallen, "Bones of Contention: Negotiating Anthropological Ethics within Fields of Ainu Refusal," Critical Asian Studies 39:4 (2007), 512-517.
} 
much blood had been taken. I felt that no one should go if that was how we were treated, but the village leaders rounded up people with this argument and that. ${ }^{315}$

\section{The New Wave of Ainu Activism}

Indignities and traumas like Kayano's gave rise to a new, more radical activist movement in the 1960 s and 1970 s that rejected the AAH' $\mathrm{S}^{316}$ position on assimilation and their close relationship with the state. The ethos of this new wave of activism was one of confrontation with the institutions of colonialism, of forcing academics and politicians to be accountable for past injustices and, in the process, asserting a new, proud Ainu identity. An early sign of this shift occurred during the Meiji Restoration Centennial in 1968 when a letter published in a major newspaper told Japanese attendees not to forget that the Hokkaido celebration site was "soaked" in "the blood shed by us Ainu.",317 One of the leading groups at the time, Ainu Kaihō Dōmei (Ainu Liberation League), was inspired by Buraku and Zainichi Korean ${ }^{318}$ rights groups with established ties to left-wing organizations and the labor movement, and they also looked to student protests against America's war with Vietnam breaking out in Japan's larger cities.

In 1972, the Ainu Liberation League adopted the tactic of kyūdan tōsō (denunciation struggle) from Buraku activists and disrupted a national anthropology

\footnotetext{
${ }^{315}$ Kayano Shigeru, Our Land Was a Forest: An Ainu Memoir, trans. Kyoko Selden and Lili Selden (Boulder: Westview Press, 1994), 98-99.

${ }^{316}$ In 1960 the Hokkaidō Ainu Kyōkai was renamed the Hokkaidō Utari Kyōkai, 'Utari' (brethren, comrades) becoming something of a euphemism, as many believed the word 'Ainu' carried too strong a stigma. The organization changed its name back to the original in 2009.

${ }^{317}$ Totsuka Miwako, untitled letter, Hokkaido Shimbun, May 13,1968.

${ }^{318}$ The Buraku (outsider caste) and Koreans residing in Japan after the Pacific War faced social situations similar to the Ainu (segregated education, poverty, discrimination, etc.), though during the early postwar decades they had a more vibrant and successful activist scene than that of Ainu communities in rural Hokkaido. See Jeffrey Paul Bayliss, On the Margins of Empire: Buraku and Korean Identity in Prewar and Wartime Japan (Cambridge: Harvard University Asia Center, 2013), and Timothy D. Amos, Embodying Difference: The Making of Burakumin in Modern Japan (Honolulu: University of Hawai'i Press, 2011).
} 
conference at Sapporo Medical University, chastising the scholars for their role in disseminating the myth of the 'dying Ainu,' and demanding they acknowledge the Ainu as people "living in the present" who would "not become extinct." ${ }^{\text {"19 }}$ The scholars ignored them, but later the conference chairman was pressured into issuing an apology after calling the demonstrators "childish" in a press interview. The denunciation strategy was again utilized during a six-month protest at Hokkaido University to publicly denounce Professor Hayashi Yoshihige, a scholar notorious for his frequent racist remarks about the Ainu in lectures ${ }^{320}$ - he, too, was forced to make a public apologyand also against media organizations, resulting in controversial shows being cancelled, on-air apologies issued, and magazines and newspapers recalled. They also directed their attacks against the Japan Travel Bureau after it placed advertisements in the Englishlanguage newspaper The Japan Times inviting foreign tourists and residents to make the journey to Hokkaido to see a "real Ainu village" and experience the "ancient customs and culture of the famed hairy Ainu. ${ }^{321}$ These examples show how the new Ainu activism was able to successfully challenge institutions that had long contributed to their exoticization and accompanying discrimination.

Yet, like with the Weather Underground in the United States and the 1968 Paris Riots, Ainu activism during the period occasionally took a dark and violent detour. The

\footnotetext{
${ }^{319}$ Hanazaki Kōhei, "Ainu Moshir and Yaponesia: Ainu and Okinawan Identities in Contemporary Japan," trans. Mark Hudson, in Multicultural Japan: Paleolithic to Postmodern, ed. Donald Denoon, Mark Hudson, Gavan McCormack, and Tessa Morris-Suzuki (Cambridge: Cambridge University Press, 2001), 124-125; lewallen, "Bones," 518; Henry Stewart, Nihon minzokugakkai dai-25 kai kenkyū taikai no bunkakai hōkoku [25th Conference of the Japanese Society of Ethnology, Featured Panel Report], Minzokugaku Kenkyū 53 (1988), 91-95.

${ }^{320}$ Richard Siddle, "Academic Exploitation and Indigenous Resistance: The Case of the Ainu," in Indigenous Minorities, 43-45.

${ }^{321}$ Siddle, Race, 167.
} 
defacement and destruction of contested monuments was fairly commonplace. In one incident, a controversial statue in Asahikawa was destroyed using explosives. The statue had featured four young Japanese pioneers standing over a sitting Ainu elder-in the original plans the elder was supposed to be kneeling — and local Ainu, led by the artist Sunazawa Bikki, ${ }^{322}$ protested the unveiling of the statue believing it a symbol of Ainu subjugation. An arson attack was also carried out against a tourism company headquarters in Shiraoi. The two worst episodes, however, were carried out by Japanese activists claiming to act in the name of Ainu rights. The first was the stabbing and attempted murder of the Shiraoi mayor in 1974 by a lone assailant who condemned him for commodifying Ainu culture. ${ }^{323}$ This incident was followed by the 1976 bombing of the Hokkaido Government Office in Sapporo in which two people were killed along with ninety injured. In this case, after a prolonged investigation of radical Ainu groups, the police discovered that the attack was actually the work of the Okami (Wolf) terrorist cell, members of the far-left anarchist group Higashi Ajia Hannichi Busō (East Asia AntiJapan Armed Front) that had engaged in a bombing campaign to avenge Korean and Ainu victims of Japanese imperialism. ${ }^{324}$

In addition to confronting colonial institutions and contesting symbols of state power another important goal of these new activist groups was to establish a contemporary Ainu identity, one that required the refashioning of traditional cultural symbols and a new

\footnotetext{
${ }^{322}$ Sunazawa Bikki (1931-1989) was a celebrated Ainu woodcarver and artist, and the son of Sunazawa Ichitarō, a Chikabumi Ainu activist in the 1920s and 1930s with Communist leanings. The Chikabumi Ainu have a long tradition of local activism in Asahikawa going back to the turn of the twentieth century.

${ }^{323}$ Morris-Suzuki, "Tourists," and Siddle, Race, 164, 165-166.

${ }^{324}$ The group's leader, Daidōji Masashi, was raised in Kushiro and attended school with many Ainu children. The name of their cell, Okami, was a reference to the extinction of Japan's wolves discussed earlier in this chapter.
} 
understanding of their past. Siddle refers to Ainu activities from the 1960s to the present as having contributed to the formation of Ainu "indigenous nationalism" rooted in a mythical and romanticized interpretation of a traditional Ainu homeland, "a modern cultural construction that bears little resemblance to historical and ethnographic evidence" but that validates "the new narrative of the modern Ainu movement [making] it as real and important as the idealized world of Edo is for modern Japanese. ${ }^{, 325}$ The activists united behind the creation of a historical counter-narrative centered on Ainu resistance to Japanese colonialism, one that challenged the dominant version of Hokkaido history and its tales of pioneers 'developing' an 'empty land.' Yūki Shōji, the founder of the Ainu Liberation League, describes the Ainu homeland—Ainu Mosir—as "haha naru daichi (Mother Earth) that formed Ainu culture, and remains unchanged to this day...the territory, albeit spiritually, of our people." ${ }^{, 26}$ Invoking "Ainu Mosir" became a common way for Yūki's fellow activists to imbue their political activities with a deeper sense of cultural meaning, as a search for an identity shared by all Ainu people, distinct from and in tension with mainstream Japanese society.

Radical activists were hardly alone in their search for new contemporary identities. They were joined by prominent members of the Ainu community, most of whom felt a renewed calling, a "clamoring in the blood" as it is often referred to in these circles, to explore their Ainu roots. ${ }^{327}$ Kayano Shigeru's establishment of the Nibutani Ainu Cultural Museum — the first Ainu museum founded by an Ainu figure—and Ainu

\footnotetext{
${ }^{325}$ Richard Siddle, “The Making of Ainu Moshiri: Japan's Indigenous Nationalism and its Cultural Fictions," in Nationalisms in Japan, ed. Shimazu Naoko (New York: Routledge, 2006), 112.

${ }^{326}$ Yūki Shōji, Ainu sengen [The Ainu Manifesto] (Tokyo: Sanichi Shobō, 1980), 43.

${ }^{327}$ Lewallen, "Clamoring Blood," 50-76.
} 
language schools created a space for Ainu of all generations to learn about their ancestral culture and experiment with ways to make it part of their contemporary lived experience. The pairing of Ainu elder Yamamoto Tasuke with a group of young artists in Lake Akan led to the creation of the Akan Yukar Theater, a venue that allows young Ainu to learn traditional Ainu songs, stories, and dances, while also exhibiting these for Akan's substantial tourist market. ${ }^{328}$ In 1974, Yamamoto and Yūki Shōji of the Buraku Liberation League joined forces to perform an icharpa (traditional memorial service) for thirtyseven Ainu who were executed in 1789 after they led a revolt against the oppressive conditions in an Edo-period commercial fishery. ${ }^{329}$ This 'invented' traditional ceremony, as well as others celebrating the life of Shakushain — now a symbolic figure of the Ainu's historical resistance to Japanese colonialism—-have since become annual events.

The wave of radical Ainu activism that began in the 1960s faded by the end of the following decade, as many of the activists became more involved in efforts to preserve, promote, and revitalize their cultural heritage, a shift that put them into dialogue with Ainu in the tourism industry. Furthermore, Ainu participation in the global indigenous rights movement brought the goals of former radicals into alignment with those in the Hokkaido Ainu Kyōkai (AAH). This shift began in 1973 when the Chinese Ambassador invited fifteen Ainu to the People's Republic to meet with members of the various indigenous minority groups there. ${ }^{330}$ This was then followed by a trip by the Lake Akan Ainu Yukar Theater group to Paris in 1976 where they performed at a UNESCO world

\footnotetext{
${ }^{328}$ Cheung, "Rethinking," 206-208.

${ }_{330}^{329}$ This refers to Menashi-Kunashir Rebellion. Siddle, Race, 174.

${ }^{330}$ Ibid., 177.
} 
heritage festival. ${ }^{331}$ Following this, in 1977, the head of the AAH, Nomura Giichi, was invited by Inuit representatives to visit Alaska; Nomura ventured there the following year and was impressed by the high degree of autonomy possessed by the indigenous peoples of the North American arctic. ${ }^{332}$ Experiences of transcontinental indigenous contact increased in frequency and altered the mission of the AAH. They abandoned their position supporting assimilation and welfare funding from the Japanese state vis-a-vis the 1899 Protection Act; instead, as the influence of radical Ainu activism waned, it was the conservative AAH that called for the abolition of the Protection Act and readied for a political struggle with the Japanese state over recognition of their indigenous rights.

\section{Conclusion: Global Indigenous Rights and Ainu Cultural Revitalization}

In 1984, the AAH petitioned the government requesting the termination of the Protection Act and the establishment of a new law to take its place that recognized the Ainu as the indigenous people of northern Japan. Predictably, their appeal was disregarded. In 1986, Prime Minister Nakasone Yasuhiro gave voice to the most tired of platitudes echoed ubiquitously in postwar society, namely that Japan is "a racially homogenous nation." ${ }^{333}$ Ainu people of all stripes were incensed by these comments and equally frustrated with the failure of bilateral negotiations with Nakasone's administration. In response, the AAH undertook a strategy of legal and political triangulation, electing to send representatives in 1987 to participate in the United Nations

\footnotetext{
331 "Parikko Kandō" [The Parisians are Moved], Asahi Shimbun, May 1, 1976.

332 Siddle, Race, 177.

${ }^{333}$ Kozo Mizoguchi, "Premier Apologizes to Japan's Ainu for Remarks on Race," Associated Press, November 4, 1986.
} 
Working Group for the United Nations Declaration on the Rights of Indigenous Peoples (UNDRIP).

In 1991, the chairwoman of the Working Group visited Japan to investigate the Ainu's political situation and criticized the government for being out of compliance with international agreements that affirmed ethnic and minority rights. The ensuing embarrassment led the government to recognize the Ainu as a "minority group," though they expressly and intentionally avoided the use of the word "indigenous." ${ }^{334}$ The following year, the United Nations did officially recognize Ainu indigeneity, and AAH Chairman, Nomura Giichi, was invited to address the General Assembly as it ushered in the International Year of the World's Indigenous People. In his speech, Nomura voiced his concern to the delegates regarding various international actions by Japanese entities that had endangered the livelihoods of the world's indigenous peoples, claiming that they were, indeed, "linked to the indifference shown toward indigenous peoples within Japan. ${ }^{1335}$ This included Japanese companies involved in activities that destroyed local environments crucial to indigenous peoples livelihoods, as well as the government's diplomatic support of states that violently oppressed them. After Nomura's address, the Japanese government established negotiations with the Ainu and the 1997 Ainu Shinpō (Ainu New Law) was passed taking the place of the 1899 Protection Act, officially bringing to an end the era of assimilation. Still, the government refused to recognize the

\footnotetext{
${ }^{334}$ Simon Cotteril, “Ainu Success: The Political and Cultural Achievements of Japan's Indigenous Minority," The Asia-Pacific Journal: Japan Focus 9:12:2 (2011), 5.

${ }^{335}$ United Nations General Assembly, Special Ceremony for the International Year of the World's Indigenous People, December 10, 1992. Refer to the link below for Nomura's speech (29:35-40:50): https://www.unmultimedia.org/avlibrary/asset/2308/2308614/.
} 
Ainu as an indigenous people; as such, the Ainu Shinpō did not satisfy all of the Ainu activists' political demands.

While these activists redoubled their efforts using the United Nations and various international institutions to generate foreign pressure on the Japanese government, Ainu groups in Hokkaido were working to protect and enliven Ainu culture through a process that involved the formation of trans-indigenous alliances, as well as attempts to educate global publics through the sharing of Ainu culture. Many of the Ainu who choose to participate in ethnotourism believe their work is necessary to resolve harmful stereotypes about their people, not only those of outsiders but those held by Ainu people themselves. Ainu tourism and educational organizations saw their influence rise as activists succeeded in raising the Ainu's domestic and international profile, giving them greater opportunities to communicate with foreign and Japanese visitors, and to help Ainu of all ages learn about and experiment with various elements of Ainu culture in daily life. In this sense, the cultural expressions found in ethnotourism are not based in the sterile retention and maintenance of static, ancient customs, rather they embody an inherent spiritual value allowing participants the opportunity to forge new cultural identities that speak to their present experiences while engaging in an ongoing dialogue with the past.

Ainu activist and tourism-oriented groups continue to engage in international exchanges in Canada, the United States, China, Sweden and numerous other nations, and have used these opportunities to study the strategies of other indigenous peoples to preserve and promote their culture and assert their rights. One example of this can be seen in the recent movement to repatriate the 2,300 boxes of appropriated ancestral 
remains that are currently in the possession of university research departments. ${ }^{336}$ In the early 1980s, Ainu organizations joined a swelling chorus of global indigenous activists demanding the return of sacred items, none more so than the bodily remains of their ancestors. Initial attempts at arbitration with Hokkaido University-the university with the largest such collection-were led by the AAH and broke down until the Ministry of Education urged the university to build a memorial hall where Ainu groups could perform annual rites for the deceased. ${ }^{337}$ This arrangement continued until 2002, when at the nineteenth icharpa ceremony visitors were finally permitted to enter the memorial. They were horrified upon seeing the haphazard way the remains had been arranged - thrown together into plastic boxes with bone fragments from different bodies stored in the same units. $^{338}$

This incident set off a long series of negotiations and lawsuits with several universities that continues to the present. Kotan no Kai-the group that led the protest against the recently-passed 2019 law over the government's plan to transfer these remains to an ossuary at the new Shiraoi Ainu museum-have played a large role in successfully suing for some of the remains to be returned to individual families and communities. ${ }^{339}$ One of the government's conditions for this type of arrangement is that Kotan no kai are required to maintain the graves of the reinterred remains, meaning they must perform

\footnotetext{
${ }^{336}$ Nakamura Naohiro, "Redressing Injustice of the Past: The Repatriation of Ainu Human Remains," Japan Forum (2018), 7-9.

${ }^{337}$ Thirty-five of the remains were returned to local branches of the AAH between 1985 and 2001 for reburial by recognized lineal descendants.

${ }^{338}$ Hokkaido University, Hokkaidō daigaku igakubu Ainu jinkotsu shūzō ikisatsu ni kan suru chōsa hōkoku sho [Report on the Ainu Human Remains Collection of Hokkaido University, School of Medicine], Sapporo, March, 2013.

${ }^{339}$ Nakamura Naohiro, "Cultural Affiliation is Not Enough: The Repatriation of Ainu Human Remains," Polar Record 53 (2017), 222-224.
} 
icharpa on an annual basis, a ritual that largely owes its continued existence to Ainu who have maintained it through working in ethnotourism.

Kotan no Kai's position on this issue puts them in tension with other activist groups and with the Ainu tourism community, both of which have been largely supportive of the move. The source of this friction is the history of the Japanese colonization of Hokkaido, the subjugation of the Ainu living there, and the forced assimilation they were made to endure. The various strains of activism that developed since the passing of the 1899 Former Natives Protection Act have continued to press for better treatment and greater rights for Ainu communities, despite the fact that across generations the language and concepts used to express this (pro-assimilation, welfare reform, Ainu pride, indigenous rights, etc.) have undergone considerable change.

So, too, has Ainu ethnotourism evolved over the years. Critics may still argue that Ainu ethnotourism has perpetuated racial stereotypes, casting the Ainu as 'vanishing primitives' and contributing to a perpetual cycle of discrimination. Supporters of tourism counter this arguing that their activities do the opposite: they allow Ainu people to engage in meaningful dialogue with Japanese and foreign visitors who too often have a limited understanding of the history of colonial oppression the Ainu have faced and resisted against. It is likely that Ainu tourism, for all its discontents, was one of the only viable means to preserve and revitalize Ainu cultural identities in the face of the Japanese government's attempts to snuff them out. And activists and ethnotourism supporters, whatever their disagreements, continue to be bound together by this shared history, as they engage in an ongoing debate on what it means to be Ainu in the twenty-first century. 


\section{Conclusion}

This work examined the multitudinous identities fashioned out of the uneven colonial power dynamics that comprised Japanese-Ainu relations from the mid seventeenth century to the present. Japan's colonial activities on the island of Hokkaido provided conditions that allowed for the construction of a racialized Japanese national identity. Meiji Japan eagerly adopted not only Western technology in its pursuit of national modernization, but also its systems of knowledge. During this period, the consensus within the fields of science and the humanities held the concept of race to be self-evident, and the global hierarchy erected to uphold its principles a symbol of the natural right of conquest, of the domination and oppression of 'inferior' peoples. Scientific racialist discourse also imbued colonizers with the power to craft the depictions and narratives of those they subjugated and declare their histories nonexistent, to parade them around the globe, and mold their image to suit national and imperial interests.

The people of Meiji Japan were thrust into an age of anxiety, rapid technological and social change, and fierce global competition during which they witnessed the colonization of their Asian neighbors by more powerful European states. The "rich country" and "strong military" Japan assembled to create parity with these Western empires was only one aspect of their modernization, they also required modern modes of identity to project their newfound power. It was in this context that Japan used medical and anthropological research on the living bodies of the Ainu, and on the appropriated remains of their ancestors to fashion their own racial identity. However, 'superior' races require the existence of 'inferior' ones, 
and so they projected onto the Ainu the idea that they were a "white race that [had] struggled and lost." 340

The racialist dimensions of Ainu-Japanese colonial entanglements were a thoroughly modern affair, though the dialectal relationship between the two groups dates back to the seventeenth century when Japan's encroachment on Ainu lands and its colonial activities began. We can see this in the economic subjugation of the Ainu, and the ethnographic data that augmented Ainu exotica and portrayed them as foreign "barbarians" far outside the political and cultural centers of Kyoto and Edo. We also get glimpses of this through the premodern biopolitical and cartographic projects that magnified Japanese conceptions of political and cultural space to include Ainu territory while attempting to transform the Ainu people into protected wards of a 'benevolent' state. Finally, we witness this directly in the present, as the Ainu try to reclaim the power to construct contemporary identities for themselves through activism, cultural production, and by asserting their indigeneity through the performance and commodification of culture, vying for the attention of what are primarily Japanese consumers.

Even Japan's racialized identity has taken different forms at different periods in time. During the early imperial age, as Japan gazed outward to its colonial periphery, scholars argued that the Yamato people were a "mixed-race," the result of intense hybridization in the archipelago's prehistory, while in the later stages of Japanese imperialism, after the colonial foundations had already been laid,

\footnotetext{
${ }^{340}$ Frederick Starr, The Ainu Group at the Saint Louis Exposition (Chicago: The Open Court Publishing Company, 1904), 110.
} 
eugenicists decried intermarriage between Japanese settlers and colonial subjects in Hokkaido, Taiwan, Korea, and Manchuria as a threat to the "purity" of Yamato blood, the symbolic belief that Japanese people from time immemorial had avoided mixing with other races at all. In the postwar period, a deliberately induced historical amnesia set in and the Japanese instead fixed their gaze inward and came to see themselves as a "homogenous race," quite possibly a way to distance themselves from their imperial past and obscure feelings of collective trauma and wartime guilt.

Ainu, too, went through similar changes in the Japanese racialist conception. While Japan saw itself as a proud mixed-race nation the Ainu were depicted as a "dying" race on account of their seclusion from other human groups. Japanese eugenicists who strove for Yamato racial 'purity' saw the Ainu as a source of racial 'corruption.' And when Japan started to think of itself as racially 'homogenous' the Ainu became, in the words of the late former AAH chairman, Nomura Giichi, "a people whose existence must not be admitted."341

All of these dialectical identities were rooted in the uneven power dynamics of Japan's colonial subjugation of the Ainu, Japan's first foray into imperialism. The contemporary Ainu efforts to reclaim the power to assert their existence and indigeneity, to revitalize their culture as part of the living present, not a vanished past, is their persistent struggle against this colonial legacy, the making of a new Ainu Mosir.

\footnotetext{
${ }^{341}$ United Nations General Assembly, Special Ceremony for the International Year of the World's Indigenous People, December 10, 1992. Refer to the link below for Nomura's speech (29:35-40:50): https://www.unmultimedia.org/avlibrary/asset/2308/2308614/.
} 


\section{Bibliography}

$\underline{\text { Archives }}$

National Diet Library, Tokyo, Japan

National Diet Library Digital Collections

Northern Studies Collection, Hokkaido University, Sapporo, Japan

Waseda University, Archival Collections, Tokyo, Japan

Primary Sources

"Ainu no seikatsu jittai" [Ainu Living Conditions], Hokkaidō Ainu Kyōkai, accessed October 25, 2013, https://www.ainu-assn.or.jp/ainupeople/life.html.

Arai Hakuseki. Ezo-shi. 1720.

Erwin Bälz. "åber die Rassenelemente in Ostasien, Speciell in Japan.” Mittheilungen der Deutsche Gesellschaft für Natur- und Völkerkunde Ostasiens 8 (1900).

Baelz, Erwin. Awakening Japan: The Diary of a German Doctor. Indiana University Press, 1974. Die Ostasiaten. Stuttgart, 1901.

Batchelor, John. Ainu Life and Lore: Echoes of a Departing Race. Tokyo: Kyōbunkan, 1927. -An Ainu-English-Japanese Dictionary, Including a Grammar of the Ainu Language. Tokyo: Methodist Publishing House, 1905.

A Grammar of the Ainu Language. Yokohama: Kelly \& Walsh, 1903. "Steps by the Way." Unpublished manuscript.

Bickmore, Albert L. "The Ainos, or Hairy Men of Yesso." American Journal of Sciences 45 (1868).

Bird, Isabella Lucy. Unbeaten Tracks in Japan: An Account of Travels on Horseback in the Interior. Vol. 2, New York: G. P. Putnam's Sons, 1881.

Blumenbach, Johann Friedrich. The Anthropological Treatises. Edited and translated by Thomas Bendishe. London: Anthropological Society, 1865.

Buffon, Georges-Louis Leclerc Comte de. A Natural History, General and Particular. Vol. 1, translated by William Smellie. London: Richard Evans, Paternoster-Row, and John Bourne, 1817.

Bülow, Fürst Bernhard von. Memoirs of Prince von Bülow. Vol. 2. Translated by Geoffrey Dunlop and F. A. Voight. Boston: Little, Brown and Company, 1932.

Campus, Petrus. Demonstrationum anatomico-pathologicarum. 1760.

Chiri Mashio. Ainugo nyūmon [An Ainu Primer]. Sapporo: Nire shobō, 1956.

Crosland, Thomas William Hodgson. The Truth about Japan. London: G. Richards, 1904.

Davis, Bernhard J. "Description of a Skeleton of an Ainu Woman and of Three Skulls of Men of the Same Race." Memoirs of the Anthropological Society of London 3 (1870).

Du Bois, W. E. B. "The Color Line Belts the World." Collier's 28, October 20, 1906.

Ezokoku füzoku ninjō no sata [1791]. In Takakura Shinichiro, ed. Nihon shomin seikatsu shiryō shūsei. Vol. 4, Tokyo: Sanichi Shobō, 1969.

Fukuzawa Yukichi. An Outline of a Theory of Civilization [1875]. Translated by David A. Dilworth and G. Cameron Hurst III. New York: Columbia University Press, 2009. Sekai kunizukushi, 6 vols. Tokyo: Keiō-gijuku, 1869.

Gobineau, M. A. de. Essai Sur L'inégalité des Races Humaines [An Essay on the Inequality of Human Races]. Paris: Librairie de Firmin Didot Fréres, 1853.

Hagiwara Mojiki. "Jūtaku no kaizen wa Utari kōjō no moto" [Improving Residences, Based on Ainu Statements]. Ezo no hikari 3 (1931). Reprinted in Ainu shi: Katsudōshin hen, edited by Hokkaidō Utari Kyōkai. Sapporo: Hokkaidō Utari Kyōkai, 1994.

Hiraoka Sadatarō. "Ainu jinshu shobun ron" [On the Management of the Ainu Race]. In Aoyama Tōen, Kyokuhoku no bettenchi. Tokyo: Hōbunsha, 1918. 
http://dl.ndl.go.jp/info:ndlip/pid/959144.

Hitchcock, Romyn. The Ainos of Yezo, Japan. Washington D.C., Smithsonian Institution: Government Printing Office, 1891.

"Hokkaido Former Natives Protection Law." [March 1, 1899]. Translated by Richard Siddle. In Reading Colonial Japan: Text, Context, and Critique, edited by Michele M. Mason and Helen J.S. Lee. Stanford: Stanford University Press, 2012.

Hokkaido University. Hokkaidō daigaku igakubu Ainu jinkotsu shūzō ikisatsu ni kan suru chōsa hōkoku sho [Report on the Ainu Human Remains Collection of Hokkaido University, School of Medicine]. Sapporo, March, 2013.

Iboshi Hokuto, Kotan: Iboshi Hokuto Ikō [Kotan: The Posthumous Works of Iboshi Hokuto]. Tokyo: Sōfuukan, 1984.

Inoue Tetsujirō. "Bunmeishijō yori mitaru Nippon senshō no genin." Tōyō gakugei zasshi 22:283 (1905).

-Naichi zakkyoro. Tokyo: Tetsugaku shoin, 1889.

Iwaya Eitarō. "Ainu Kyōiku no hitsuyō." [The necessity of Ainu Education] Hokkaidō kyōikukai zasshi 18 (1894).

"Ainu no genshō" [The Ainu's Decline]. Hokkaidō kyōikukai zasshi 6 (1891).

Japan Diet. Ainu bunka no shinkō narabi ni Ainu no dentō tō ni kan suru chishiki no fukyū oyobi keihatsu ni kan suru hōritsu [Act on the Promotion of Ainu Culture, and Dissemination and Englightenment of Knowledge about Ainu Tradition]. 140 ${ }^{\text {th }}$ Diet, No. 52, 1997.

- Ainu minzoku wo senjūminzoku to suru koto wo mitomeru kokkai ketsugi [Diet Resolution Calling for the Recognition of the Ainu People as an Indigenous People]. 169th Diet, Res. 1, 2008.

-Ainu no hitobito no hokori ga sonchō sareru shakai wo jitsugen suru tame no shisaku no suishin ni kan suru hōritsu [Act on Promoting Measures to Realize a Society in Which the Pride of the Ainu is Respected]. $198^{\text {th }}$ Diet, No.24, 2019.

http://www.shugiin.go.jp/internet/itdb gian.nsf/html/gian/honbun/houan/g19809024.htm

Kayano Shigeru. Our Land Was a Forest: An Ainu Memoir. Translated by Kyoko Selden and Lili Selden. Boulder: Westview Press, 1994.

"Jinruikan to Ainu." Hokkaido Times. April 15, 1903.

Joest, Wilhelm. "Die Ainos." Zeitschrift für Ethnologie 14 (1882).

Kamada Ryūō. "Shingaku oku no kakehashi" [The Bridge to the Interior of Shingaku] [1822]. In Nihon shisō taikei. Vol. 42, Sekimon shingaku. Tokyo: Iwanami Shoten, 1970.

Katō Hiroyuki. "Junkoku no setsugi" [1900]. -New Treatise on the Rights of Man [1881].

Kimura Takatarō. Sekaiteki kenkyū ni motozukeru Nippon taikoshi. Tokyo: Hakubunkan, 1911.

Kindaichi Kyosuke. Ainu Life and Legends. Tokyo: Board of Tourist Industry, Japanese Government Railways, 1941.

Kodama Sakuzaemon. "Kinkyū o yōshita ainu kenkyū” [Ainu Studies Required Urgency]. Hokkaido no bunka 21 (1971).

Koganei Yoshikiyo. "Aino jinshu ni tsuite" [On the Ainu Race]. Tōkyō jinruigakkai zasshi 94 (1894). "Aino no jinshugakuteki chōsa no omohide [sic]: Yonjūhachi-nen mae no omohide" [Remembering Ainu Ethnological Surveys: Memories from the Past Forty-Eight Years]. Dolmen 4:7 (1935).

Jinruigaku kenkyū [Anthropological Research]. Tokyo: Ōokayama shoten, 1928. http://dl.ndl.go.jp/info:ndljp/pid/1018027/99.

Kozo Mizoguchi. "Premier Apologizes to Japan's Ainu for Remarks on Race.” Associated Press, November 4, 1986.

Kunikida Doppo. "The Shores of the Sorachi River" [1902]. Translated by Michelle M. Mason. In Reading Colonial Japan: Text, Context, and Critique, edited by Michele M. Mason and Helen J.S. Lee. Stanford: Stanford University Press, 2012. 
Kuwata Ryūsai. "Ezo shutō kiji" [1857]. Cited in Brett L. Walker, "The Early Modern Japanese State and Ainu Vaccinations: Redefining the Body Politic 1799_1868," Past \& Present 163

(1999).

Matsumae-chō shi henshū shitsu, ed. Matsumae-chō shi. Vol. 1, 1975.

Matsuura Takeshirō. "Kinsei Ezo jinbutsu shi” [1858]. In Matsuura Takeshirō kikōshū, edited by Yoshida Takezō. Vol. 3, Tokyo: Fuzanbō, 1975.

"Nosappu nisshi” [1858]. In Matsuura Takeshirō kikōshū, edited by Yoshida Takezō. Vol. 3, Tokyo: Fūzanbō, 1977.

"Shiretokko nisshi”" [1858] In Matsuura Takeshirō kikōshū, edited by Yoshida Takezō. Vol. 3, Tokyo: Fūzanbō, 1977.

McGee, W.J. “Anthropology at the Louisiana Purchase Exposition.” Science 22 (1905).

Mogami Tokunai. "Ezo no kuni fūzoku ninjō no sata" [Report on the Common Customs of Ezo]. In Nihon shomin seikatsu shiryō shūsei: Tanken, kikō, chishi hakuhenhen, edited by Takakura Shinichirō. Vol.4, Tokyo: Sanichi Shobō, 1969.

Moritake Takeichi. "Misemono atsukai wo chūshi seyō" [Stop Treating Us Like Spectacles]. Otaru Shimbun, August 24, 1934. Reprinted in Ainu minzoku kindai no kiroku, edited by Ogawa Masahito and Yamada Shinichi. Tokyo: Sōfūkan, 1998.

Morse, Edward S. Japan Day By Day, 1877, 1878-79, 1882-83. Vol. 2, Boston: Houghton Mifflin, 1917.

“A Pre-Aino Race in Japan.” Science 10 (1892).

"Traces of Early Man in Japan." Nature 17 (1877).

"What American Zoologists have done for Evolution." Science 32 (1887).

Morton, Samuel George. Crania Americana; or, A Comparative View of the Skulls of Various Aboriginal Nations of North and South America. Philadelphia: J. Dobson, 1839. Crania Agyptiaca; or, Observations on Egyptian Ethnography, Derived from Anatomy, History, and the Monuments. Philadelphia: J. Pennington, 1844.

Murakami Shimanojo, Ezo-shima kikan [1799].

Nihon shomin seikatsu shiryō shūsei, edited by Takakura Shinichiro. Vol. 4, Tokyo: Sanichi Shobō, 1969.

Nitobe Inazō. The Imperial Agricultural College of Sapporo, Japan. Sapporo: Imperial College of Agriculture, 1893.

Oka Asajirō. Shinka to jinsei. Tokyo: Yuseido shuppan, 1968.

"Our Japanese Visitors." Harper's Weekly, May 26, 1860.

"Our Washington Correspondence." New York Herald, May 24, 1860.

"Parikko Kandō" [The Parisians are Moved]. Asahi Shimbun, May 1, 1976.

Polo, Marco. The Book of Ser Marco Polo the Venetian concerning the Kingdoms of the East, edited by Henry Yule Vol. 2 London: John Murray, 1875.

Pratt, Richard H. "The Advantages of Mingling Indians with Whites." In Americanizing the American Indians: Writings by the 'Friends of the Indian' 1800-1900, edited by Francis Paul Prucha. Cambridge: Harvard University Press, 1973.

Siebold, Heinrich von. "Ethnologische Studien über die Ainos auf Yesso." Zeitschrift für Ethnologie 13 (1881).

Spencer, Herbert. The Principles of Biology. Vol. 1, London: Williams and Norgate, 1864.

Starr, Frederick. The Ainu Group at the Saint Louis Exposition. Chicago: The Open Court Publishing Company, 1904.

Stewart, Henry. Nihon minzokugakkai dai-25 kai kenkyū taikai no bunkakai hōkoku [25th Conference of the Japanese Society of Ethnology, Featured Panel Report]. Minzokugaku Kenkyū 53 (1988).

Taguchi Ukichi. "Kokugo jō yori kansatsu shitaru jinshu no shodai," Shigaku zasshi 12:6 (1901). "Naichi zakkyoron" [1879]. "Nippon jinshuron" [1895].

Takahashi Yoshio. Nippon jinshu kairyōron. Tokyo: Ishikawa Hanjirō, 1884. 
Takekuma Tokusaburō. Ainu Monogatari [A Tale of the Ainu]. Tokyo: Hakubunkan, 1918. http://dl.ndl.go.jp/info:ndljp/pid/958345.

Terashima Ryōan. Wakan sansei zue [1713]. Vol. 1, Tokyo: Nihon zuihitsu taisei kankōkai, 1929.

Totsuka Miwako. letter to editor. Hokkaido Shimbun, May 13, 1968.

Tsuboi Shōgorō. "Hokkaidō kyūdojin kyūiki jigyō" [An Education Project for Hokkaido Former Natives]. Tōkyō jinruigakkai zasshi 21:245 (1906).

“Jinruigakuteki chishiki no yō masumasu fukashi." Tōkyō jinruigakkai zasshi 20:233 (1905). “Koropokkuru Hokkaidō ni sumishi narubeshi” [The Koropokkuru Must Have Inhabited Hokkaido] Tōkyō jinruigakkai hōkoku 2:12 (1887).

Tsuishikari no ishibumi [The Monument of Tsuishikari]. Edited by Karafuto Ainu shi kenkyūkai. Sapporo: Hokkaidō Shuppan Kikaku Sentā, 1992.

Ueda Kazutoshi. "Kokugo to kokka to.” [1894]. In Hisamatsu Sen'ichi, ed., Meiji bungaku zenshū 44 kan: Ochiai Naobumi, Ueda Kazutoshi, Haga Yaichi, and Fujioka Sakutarō shū. Tokyo: Chikuma Shobō, 1968.

United Nations General Assembly. Resolution 61/295, United Nations Declaration on the Rights of Indigenous Peoples, sixty-first session (September 13, 2007).

Special Ceremony for the International Year of the World's Indigenous People, December 10, 1992. Refer to the link below for Nomura's speech (29:35-40:50): https://www.unmultimedia.org/avlibrary/asset/2308/2308614/.

Watanabe Kazan. "Gaikoku jijōsho,’[1839]. In Watanabe Kazan, Takano Chōei, Sakuma Shōzan, Yokoi Shōnan, Hashimoto Sanai, edited by Satō Shōsuke, Uete Michiari, and Yamaguchi Muneyuki. Tokyo: Iwanami Shoten, 1971.

“Women of Japan." Frank Leslie's Illustrated Newspaper, May 26, 1860.

Yūki Shōji. Ainu sengen [The Ainu Manifesto]. Tokyo: Sanichi Shobō, 1980.

$\underline{\text { Secondary Sources }}$

Abbott, Carl. The Great Extravaganza: Portland and the Lewis and Clark Exposition, $3^{\text {rd }}$ Edition. Portland: Oregon Historical Society Press, 2004.

Amos, Timothy D. Embodying Difference: The Making of Burakumin in Modern Japan. Honolulu: University of Hawai'i Press, 2011.

Anderson, Benedict. Imagined Communities: Reflections on the Origin and Spread of Nationalism. New York: Verso, 2006.

Asaka, Ikuko, "Colored Men of the East': African Americans and the Instability of Race in US-Japan Relations." American Quarterly 66:4 (2014).

Askew, David. "Debating the 'Japanese' Race in Meiji Japan: Toward a History of Early Japanese Anthropology." In The Making of Anthropology in East and Southeast Asia, edited by Shinji Yamashita, Joseph Bosco, and Jeremy Seymour Eades. New York: Berghahn, 2004.

Attwood, Bain. The Making of the Aborigines. Sydney: Allen and Unwin, 1989.

Bayliss, Jeffrey Paul. On the Margins of Empire: Buraku and Korean Identity in Prewar and Wartime Japan. Cambridge: Harvard University Asia Center, 2013.

"Bill Finally Recognizes Ainu as Indigenous People of Japan." The Asahi Shimbun, February 6, 2019.

Bethencourt, Francisco. Racisms: From the Crusades to the Twentieth Century. Princeton: Princeton University Press, 2013.

Bunten, Alexis Celeste. "More like Ourselves: Indigenous Capitalism through Tourism." The American Indian Quarterly 34:3 (2010).

Chakrabarty, Dipesh. Provincializing Europe: Postcolonial Thought and Historical Difference. Princeton: Princeton University Press, 2008.

Cheung, Sidney C.H. "Men, Women and 'Japanese' as Outsiders: A Case Study of Postcards with Ainu Images." Visual Anthropology 13:3 (2000).

“Rethinking Ainu Heritage: A Case of an Ainu Settlement in Hokkaido, Japan.” International Journal of Heritage Studies 11:3 (2005). 
Cortazzi, Hugh. Victorians in Japan: In and Around the Treaty Ports. London: Bloomsbury Academic, 2012.

Cotteril, Simon. "Ainu Success: The Political and Cultural Achievements of Japan's Indigenous Minority." The Asia-Pacific Journal: Japan Focus 9:12:2 (2011).

Crosby, Alfred. Ecological Imperialism: The Biological Expansion of Europe, 900-1900. Cambridge: Cambridge University Press, 1986.

Cross, Sherrie. "Prestige and Comfort: The Development of Social Darwinism in Early Meiji Japan, and the Role of Edward Sylvester Morse." Annals of Science 53:4 (1996).

De Bary, William Theodore, Carol Gluck, and Arthur E. Tiedemann, ed. Sources of Japanese Tradition. Vol. 2, 1600-2000. New York: Columbia University Press, 2005.

Denney, John. Respect and Consideration: Britain in Japan 1853-1868 and Beyond. Leicester: Radiance Press, 2011.

Dower, John W. War Without Mercy: Race and Power in the Pacific War. New York: Pantheon Books, 1986.

Dubreuil, Chisato O. "Ainu Journey: From Tourist Art to Fine Arts." In Ainu: Sprit of a Norther People, editedy William W. Fitzhugh and Chisato O. Dubreuil. Washington D.C., Smithsonian Institution, 1999.

Duke, Benjamin. The History of Modern Japanese Education: Constructing the National School System, 1872-1890. New Brunswick: Rutgers University Press, 2009.

Shimao, Eikoh. "Darwinism in Japan, 1877-1927," Annals of Science 38:1 (1981).

Elman, Benjamin A. "Sinophiles and Sinophobes in Tokugawa Japan: Politics, Classicism, and Medicine During the Eighteenth Century." East Asian Science, Technology and Society 2:1 (2008).

Emori Susumu. Ainu no rekishi: Hokkaidō no hitobito. Vol. 2, Tokyo: Sanseidō, 1987.

Fabian, Ann. The Skull Collectors: Race, Science, and America's Unburied Dead. Chicago: University of Chicago Press, 2010.

Fitzhugh, William W. "Ainu Ethnicity: A History." In Ainu: Sprit of a Norther People, edited by William W. Fitzhugh and Chisato O. Dubreuil. Washington D.C., Smithsonian Institution, 1999.

Foucault, Michel. The Birth of Biopolitics: Lectures at the Collège De France 1978-1979, edited by Michel Senellart and translated by Graham Burchell. New York: Palgrave MacMillan, 2008.

Frey, Christopher J. "Ainu Schools and Education Policy in Nineteenth-Century Hokkaido, Japan." PhD Diss., Indiana University, 2007.

Fujitani, Takashi. "Inventing, Forgetting, Remembering: Toward a Historical Ethnography of the Nation-State." In Cultural Nationalism in East Asia: Representation and Identity, edited by Harumi Befu. Berkeley: Institute of East Asian Studies, University of California, 1993.

Gluck, Carol. Japan's Modern Myths: Ideology in the Late Meiji Period. Princeton: Princeton University Press, 1987.

Godart, G. Clinton. Darwin, Dharma, and the Divine: Evolutionary Theory and Religion in Modern Japan. Honolulu: University of Hawai'i, 2017. "Darwin in Japan: Evolutionary Theory and Japan's Modernity 1820-1970." PhD diss., University of Chicago, 2009.

Gould, Stephen Jay. The Mismeasure of Man. New York: W.W. Norton, 1996.

Greenwalk, Emily. Reconfiguring the Reservation: The Nez Perces, Jicarilla Apaches, and the Dawes Act. Albuquerque: University of New Mexico Press, 2002.

Haake, Claudia B. The State, Removal and Indigenous Peoples in the United States and Mexico. New York: Routledge, 2007.

Hanazaki Kōhei. "Ainu Moshir and Yaponesia: Ainu and Okinawan Identities in Contemporary Japan," translated by Mark Hudson. In Multicultural Japan: Paleolithic to Postmodern, edited by Donald Denoon, Mark Hudson, Gavan McCormack, and Tessa Morris-Suzuki. Cambridge: Cambridge University Press, 2001.

Lisa Hiwasaki. "Ethnic Tourism in Hokkaido and the Shaping of Ainu Identity." Pacific Affairs 73:3 
(2000).

Howell, David L. "The Ainu and the Early Modern Japanese State, 1600-1868." In Ainu: Sprit of a Norther People, edited by William W. Fitzhugh and Chisato O. Dubreuil. Washington D.C., Smithsonian Institution, 1999.

“Ainu Ethnicity and the Boundaries of the Early Modern Japanese State." Past \& Present 142 (February 1994).

Geographies of Identity in Nineteenth-Century Japan. Berkeley: University of California Press, 2005.

“Making 'Useful Citizens' of Ainu Subjects in Early Twentieth-Century Japan.” The Journal of Asian Studies 63:1 (2004).

Jannetta, Ann Bowman. "Disease of the Early Modern Period in japan." In The Cambridge World History of Human Disease, edited by Kenneth F. Kiple. Cambridge: Cambridge University Press, 1993.

Epidemics and Mortality in Early Modern Japan. Princeton: Princeton University Press, 1987.

"Jennerian Vaccination and the Creation of a National Public Health Agenda in Japan, 1850 - 1900." Bulletin of the History of Medicine 83:1 (2009).

Jansen, Marius B. The Making of Modern Japan. Cambridge: Harvard University Press, 2002.

Jozuka, Emiko. “Japan's 'Vanishing' Ainu Will Finally be Recognized as Indigenous People." CNN, April 23, 2019. https://edition.ads.next.cnn.com/2019/04/20/asia/japan-ainu-indigenouspeoples-bill-intl/index.html.

Kaiho Yōko. Kindai hoppō shi: Ainu minzoku to josei to [Modern History of the Northern Regions: The Ainu People and Women]. Tokyo: Sanichi Shobō, 1992.

Kaiho Mineo. Kinsei no Hokkaido. Tokyo: Kyōikusha, 1979.

Kawai, Yuko. "Deracialised Race, Obscured Racism: Japaneseness, Western and Japanese Concepts of Race, and Modalities of Racism." Japanese Studies 35:1 (2015).

Keene, Donald. Emperor of Japan: Meiji and His World, 1852-1912. New York: Columbia University Press, 2005.

-The Japanese Discovery of Europe: Honda Toshiaki and Other Discovers 1720-1798. Stanford: Standford University Press, 1969.

Kikuchi Isao. Ainu minzoku to Nihonjin: Higashi Ajia no naka no Ezochi. Tokyo: Asahi Sensho, 1994. "Early Ainu Contacts with the Japanese/" In Ainu: Spirit of a Northern People, edited by William W. Fitzhugh and Chisato O. Dubreuil. Arctic Studies Center, National Museum of Natural History, Smithsonian Institution: Washington D.C., 1999.

-Hoppōshi no naka no kinsei Nihon [Early Modern Japan in Northern History]. Tokyo: Azekura shobō, 1991.

Kimura, Kayoko. “Japan's Indigenous Ainu Sue to Bring Their Ancestors' Bones Back Home.” The Japan Times, July 25, 2018. https://www.japantimes.co.jp/news/2018/07/25/national/japansindigenous-ainu-sue-bring-ancestors-bones-back-home/\#.Xa4XiJMzaFU.

Koida Takeru. Ainu funbo tōkutsu jiken [Ainu Illegal Grave-Digging Scandals]. Sapporo: Miyama Shobō, 1987.

Kojina Kyōko. "The Making of Ainu Citizenship from the Viewpoint of Gender and Ethnicity." Translated by Leonie Stickland. In Gender, Nation and State in Modern Japan, edited by Andrea Germer, Vera Mackie and Ulrike Wöhr. New York: Routledge, 2014.

Kowner, Rotem. From White to Yellow: The Japanese in European Racial Thought, 1300-1735. Montreal and Kingston: McGill-Queen's University Press, 2014.

"Lighter than Yellow, but not Enough': Western Discourse on the Japanese 'Race." The Historical Journal 43:1 (2000).

Kreiner, Josef. " The European Image of the Ainu as Reflected in Museum Collections." In Ainu: Sprit of a Norther People, edited by William W. Fitzhugh and Chisato O. Dubreuil. Washington D.C., Smithsonian Institution, 1999. 
Lake, Marilyn and Henry Reynolds. Drawing the Global Colour Line: White Men's Countries and the International Challenge of Racial Equality. Cambridge: Cambridge University Press, 2008.

lewallen, ann-elise. "Bones of Contention: Negotiating Anthropological Ethics within Fields of Ainu Refusal." Critical Asian Studies 39:4 (2007).

"Clamoring Blood': The Materiality of Belonging in Modern Ainu Identity." Critical Asian Studies 48:1 (2016).

"Human Rights and Cyber Hate Speech: The Case of the Ainu." Asia-Pacific Human Rights Information Center: Focus 81 (2015).

Limerick, Patricia Nelson. The Legacy of Conquest: The Unbroken Past of the American West. New York: W.W. Norton \& Company, Inc., 1987.

Low, Morris. "Physical Anthropology in Japan: The Ainu and the Search for the Origins of the Japanese." Current Anthropology 53:5 (2012).

Ludley, Elizabeth D. Reforming Japan: The Woman's Christian Temperance Union in Meiji Japan. Honolulu: University of Hawai'i Press, 2010.

Marcon, Federico. The Knowledge of Nature and the Nature of Knowledge in Early Modern Japan. Chicago: The University of Chicago Press, 2015.

Mason, Michele M. and Helen J.S. Lee, "Introduction." In Reading Colonial Japan: Text, Context, and Critique, edited by Michele M. Mason and Helen J.S. Lee. Stanford: Stanford University Press, 2012.

McDonnell, Janet A. The Dispossession of the American Indians, 1887-1934. Bloomington: Indiana University Press, 1991.

Medak-Saltzmann, Danika. "Staging Empire: The Display and Erasure of Indigenous Peoples in Japanese and American Nation Building Projects." PhD diss., University of California, Berkeley, 2008.

"Transnational Indigenous Exchange: Rethinking Global Interactions of Indigenous Peoples at the 1904 St. Louis Exposition." American Quarterly 62:3 (September 2010).

Meijer, Miriam Claude and Petrus Camper. "Petrus Camper on the Origin and Color of Blacks." History of Anthropology Newsletter 24:2 (1997).

Meijer, Miriam Claude. Race and Aesthetics in the Anthropology of Petrus Camper 1722-1789. Amsterdam: Lodopi, 1999.

Mitsuda Tatsuya. "Vegetarian' Nationalism: Critiques of Meat Eating for Japanese Bodies, 1880 1938." In Culinary Nationalism in Asia, edited by Michelle T. King. New York: Bloomsbury Academic, 2019.

Morris-Suzuki, Tessa. "A Descent into the Past: The Frontier in the Construction of Japanese Identity." In Multicultural Japan: Palaeolithic to Postmodern, edited by Donald Denoon, Mark Hudson, Gavan McCormack, and Tessa Morris-Suzuki. Cambridge: Cambridge University Press, 1996.

"Performing Ethnic Harmony: The Japanese Government's Plans for a New Ainu Law." The Asia-Pacific Journal: Japan Focus 16:21:2 (November, 2018).

Re-Inventing Japan: Time, Space, Nation. New York: Routledge, 1998.

"Tourists, Anthropologists, and Visions of Indigenous Society in Japan." In Beyond Ainu Studies: Changing Academic and Public Perspectives, edited by Mark J. Hudson, ann-elise lewallen, and Mark K. Watson. Honolulu: University of Hawai'i Press, 2014.

Nakamura Naohiro. "Cultural Affiliation is Not Enough: The Repatriation of Ainu Human Remains." Polar Record 53 (2017).

"Redressing Injustice of the Past: The Repatriation of Ainu Human Remains." Japan Forum $31: 3(2018)$.

Laura Nenzi. Excursions in Identity: Travel and the Intersection of Place, Gender, and Status in Edo Japan. Honolulu: University of Hawai'i Press, 2008.

Ogawa Masahito. "The Hokkaido Former Aborigines Protection Act and Assimilatory Education." In Indigenous Minorities and Education: Australian and Japanese Perspectives on their 
Indigenous Peoples, the Ainu, Aborigines, and Torres Strait Islanders, edited by Noel Loos and Osanai Takeshi. Tokyo: Sanyūsha, 1993.

Kindai Ainu kyoiku seidoshi kenkyu [Study of the Modern Ainu Educational System]. Sapporo: Hokkaido Daigaku Tosho Kankyokai, 1997.

Oguma Eiji. The Boundaries of 'the Japanese': Korea, Taiwan and the Ainu 1868-1945. Vol. 2, translated by Leonie R. Stickland. Melbourne: Trans Pacific Press, 2017.

- A Genealogy of Japanese Self-Images. Translated by David Askew. Melbourne: Trans Pacific Press, 2002.

Ohtsuka Kazuyoshi. "Tourism, Assimilation, and Ainu Survival Today." In Ainu: Sprit of a Norther People, edited by William W. Fitzhugh and Chisato O. Dubreuil. Washington D.C., Smithsonian Institution, 1999.

Osamu Sakura. "Similarities and Varieties: A Brief Sketch on the Reception of Darwinism and Sociobiology in Japan." Biology and Philosophy 13 (1998).

Parezo, Nancy J. and Don D. Fowler. Anthropology Goes to the Fair: The 1904 Louisiana Purchase Exposition. Lincoln: University of Nebraska Press, 2007.

Platt, Brian. "Japanese Childhood, Modern Childhood: The Nation-State, the School, and $19^{\text {th }}$-Century Globalization." Journal of Social History 38:4 (2005).

Pratt, Mary Louise. Imperial Eyes: Travel Writing and Transculturation. New York: Routledge, 1992.

Qureshi, Sadiah. Peoples on Parade: Exhibitions, Empire, and Anthropology in Nineteenth-Century Britain. Chicago: The University of Chicago Press, 2011.

Refsing, Kirsten. "Lost Aryans?: John Batchelor and the Colonization of the Ainu Language." Interventions 2:1 (2000).

Ruoff, Kenneth J. Imperial Japan at its Zenith: The Wartime Celebration of the Empire's 2,600 Anniversary. Ithaca: Cornell University Press, 2010.

Rydell, Robert W. All the World's a Fair: Visions of Empire at American International Expositions, 18761916. Chicago: University of Chicago Press, 1984.

Saito Chie. "Senjūken no hoshō wo Ainu minzoku dantai ga shūkai" [Ainu groups gather to secure indigenous rights]. Hokkaido Shimbun. March 4, 2019. https://www.hokkaidonp.co.jp/article/282580.

Sasaki Toshikazu. “Ainu-e: A Historical Review.” In Ainu: Spirit of a Northern People, edited by William W. Fitzhugh and Chisato O. Dubreuil. Arctic Studies Center, National Museum of Natural History, Smithsonian Institution: Washington D.C., 1999.

Ainu eshi no kenkyu $\bar{u}$ [Research on the Artistic and Written Depictions of the Ainu]. Tokyo: Sōfūkan, 2004.

"Iomante kō: Shamo ni yoru Ainu bunka rikai no kōsatsu" [A Study of Iomante: Considering Japanese Perspectives on Ainu Culture]. Rekishigaku kenkyū 613 (1990).

Schiebinger, Londa. Plants and Empire: Colonial Bioprospecting in the Atlantic World. Cambridge: Harvard University Press, 2004.

Screech, Timon. The Lens Within the Heart: The Western Scientific Gaze and Popular Imagery in later Edo Japan. New York: Routledge, 2002.

Shimazu Naoko. Japanese Society at War: Death, Memory and the Russo-Japanese War. Cambridge: Cambridge University Press, 2009.

Shirayama Tomomasa. Matsumae Ezo-chi basho ukeoi seido no kenkyū. Tokyo: Genandō shoten, 1971.

Siddle, Richard. "Academic Exploitation and Indigenous Resistance: The Case of the Ainu." In Indigenous Minorities and Education: Australian and Japanese Perspectives of their Indigenous Peoples, the Ainu, Aborigines and Torres Strait Islanders, edited by Noel Loos and Takeshi Osanai. Tokyo: Sanyūsha, 1993.

"From Assimilation to Indigenous Rights: Ainu Resistance Since 1869." In Ainu: Sprit of a Norther People, edited by William W. Fitzhugh and Chisato O. Dubreuil. Washington D.C., Smithsonian Institution, 1999.

“The Making of Ainu Moshiri: Japan's Indigenous Nationalism and its Cultural Fictions." In 
Nationalisms in Japan, edited by Shimazu Naoko. New York: Routledge, 2006.

Race, Resistance and the Ainu of Japan. New York: Routledge, 1996.

Simpson, Bob. "Tourism and Tradition from Healing to Heritage." Annals of Tourism Research 20:1 (1993).

Steinberg, John W., Bruce W. Menning, David Schimmelpenninck Van Der Oye, David Wolff, and Shinji Yokote, ed. The Russo-Japanese War in Global Perspective: World War Zero, Vol. 1, Boston: Brill, 2005.

Sullivan, Gregory. "The Instinctual Nation-State: Non-Darwinian Theories, State Science and UltraNationalism in Oka Asajirō's 'Evolution and Human Life." Journal of the History of Biology 44:3 (2011).

Takakura Shinichirō. The Ainu of Northern Japan: A Study in Conquest and Acculturation, translated by John A. Harrison. Philadelphia: American Philosophical Society, 1960.

-Ainu seisakushi. Tokyo: Nihon Hyōronsha, 1943.

Takeda, Nazumi and James Williams. "Plurality, Identity, and the State: National Education Policy Towards Indigenous Minorities in Japan and Canada." Comparative Education 44:1 (February, 2008).

Takezawa Yasuko. “Translating and Transforming 'Race:' Early Meiji Period Textbooks.” Japanese Studies 35:1 (2015).

Tamura Suzuko. "Ainu Language: Features and Relationships.” In Ainu: Sprit of a Norther People, edited by William W. Fitzhugh and Chisato O. Dubreuil. Washington D.C., Smithsonian Institution, 1999.

Tanaka, Stefan. Japan's Orient: Rendering Pasts into History. Berkeley: University of California Press, 1995.

Toby, Ronald P. “Imagining and Imaging ‘Anthropos' in Early-Modern Japan.” Visual Anthropology Review 14:1 (1998).

Tomita Torao. "Hokkaidō kyūdojin hogo hō to Dōzu hō: Hikakushiteki kenkyū no kokoromi" [The Hokkaido Former Natives Protection Act and the Dawes Act: Attempting a Comparative Historical Study]. Jinbungakkai kiyō 45 (1989).

Totman, Conrad. Early Modern Japan. Berkeley: University of California Press, 1993.

Trafford, Emily. "Hitting the Trail: Live Displays of Native American, Filipino, and Japanese People at the Portland World's Fair." Oregon Historical Quarterly 116:2 (2015).

Unoura Hiroshi. "Samurai Darwinism: Hiroyuki Katō and the Reception of Darwin's Theory in Modern Japan from the 1880s to the 1900s." History and Anthropology 11:2-3 (1999).

Vaporis, Constantine Nomikos. Breaking Barriers: Travel and the State in Early Modern Japan. Cambridge: Harvard University Press, 1995.

Veracini, Lorenzo. "Understanding Colonialism and Settler Colonialism as Distinct Formations." Interventions 16:5 (2014).

Walker, Brett L. The Conquest of Ainu Lands: Ecology and Culture in Japanese Expansion, 15901800. Berkeley: University of California Press, 2001.

"The Early Modern Japanese State and Ainu Vaccinations: Redefining the Body Politic 1799-1868." Past \& Present 163 (1999).

The Lost Wolves of Japan. Seattle: University of Washington Press, 2005.

"Mamiya Rinzō and the Japanese Exploration of Sakhalin Island: Cartography and Empire." Journal of Historical Geography 33 (2007).

"Meiji Modernization, Scientific Agriculture, and the Destruction of Japan's Hokkaido

Wolf." Environmental History 9:2 (2004).

Watanabe Masao. The Japanese and Western Science, translated by Otto Theodor Benfey. Philadelphia: University of Pennsylvania Press, 1990.

Watson, Mark K. Japan's Ainu Minority in Tokyo: Diasporic Indigeneity and Urban Politics. New York: Routledge, 2014.

Weiner, Michael. "Discourse of Race, Nation and Empire in pre-1945 Japan." Ethnic and Racial Studies 18:3 (1995). 
“The Invention of Identity: Race and Nation in Pre-war Japan.” In The Construction of Racial Identities in China and Japan, edited by Frank Dikötter. Hong Kong: Hong Kong University Press, 1997.

Winchester, Mark. "Everything You Know About Ainu is Wrong: Kobayashi Yoshimori's Excursion into Ainu Historiography." The Asia-Pacific Journal: Japan Focus 9:22:1 (2011).

Wolfe, Patrick. "Settler Colonialism and the Elimination of the Native." Journal of Genocide Research 8:4 (2006).

Wolff, David, Steven G. Marks, Bruce W. Menning, David Schimmelpenninck Van Der Oye, John W. Steinberg, Yokote Shinji, ed. The Russo-Japanese War in Global Perspective: World War Zero, Vol. 2, Boston: Brill, 2007.

Yamaji Katsuhiko. Kindai Nihon no shokuminchi hakurankai [Modern Japanese Colonial Expositions] Tokyo: Fūkyōsha, 2008.

Yamashita Shigekazu. Supensā to Nihon kindai [Spencer and Modern Japan]. Tokyo: Ochanomizu shobō, 1983.

Yamashita Shinji. "Somewhere in Between: Towards an Interactive Anthropology in a World Anthropologies Project." In Dismantling the East-West Dichotomy, edited by Joy Hendry and Heung Wah Wong. New York: Routledge, 2006.

Yonemoto, Marcia. Mapping Early Modern Japan: State, Place, and Culture in the Tokugawa Period 1603-1868. Berkeley: University of California Press, 2003. “The 'Spatial Vernacular' in Tokugawa Maps,” The Journal of Asian Studies 59:3 (2000)

Yoshinobu Kotani. "Ainu Collections in North America: Documentation Projects and the Frederick Starr Collections." In Ainu: Sprit of a Norther People, edited by William W. Fitzhugh and Chisato O. Dubreuil. Washington D.C., Smithsonian Institution, 1999. 